University of Louisville

ThinkIR: The University of Louisville's Institutional Repository

$12-2019$

\title{
Education abroad participation: predicting participation through high school academic record and intent to be involved in college as reported in the freshman survey (TFS) and in the college senior survey (CSS).
}

Elizabeth Karen Liebschutz-Roettger

University of Louisville

Follow this and additional works at: https://ir.library.louisville.edu/etd

Part of the Scholarship of Teaching and Learning Commons

\section{Recommended Citation}

Liebschutz-Roettger, Elizabeth Karen, "Education abroad participation: predicting participation through high school academic record and intent to be involved in college as reported in the freshman survey (TFS) and in the college senior survey (CSS)." (2019). Electronic Theses and Dissertations. Paper 3309.

https://doi.org/10.18297/etd/3309

This Doctoral Dissertation is brought to you for free and open access by ThinkIR: The University of Louisville's Institutional Repository. It has been accepted for inclusion in Electronic Theses and Dissertations by an authorized administrator of ThinkIR: The University of Louisville's Institutional Repository. This title appears here courtesy of the author, who has retained all other copyrights. For more information, please contact thinkir@louisville.edu. 


\title{
EDUCATION ABROAD PARTICIPATION: PREDICTING PARTICIPATION THROUGH HIGH SCHOOL ACADEMIC RECORD AND INTENT TO BE INVOLVED IN COLLEGE AS REPORTED IN THE FRESHMAN SURVEY (TFS) AND IN THE COLLEGE SENIOR SURVEY (CSS) \\ by \\ Elizabeth Karen Liebschutz-Roettger \\ MS, (2012), University of Kentucky \\ MA, (2004), DePaul University \\ BA, (2000), Lake Forest College
}

\begin{abstract}
A Dissertation
Submitted to the Faculty of the College of Education and Human Development of the University of Louisville in Partial Fulfillment for the Requirements

for the Degree of
\end{abstract}

Doctor of Philosophy in

Counseling and Personnel Services

Department of Educational \& Counseling Psychology,

Counseling, and College Student Personnel

University of Louisville

December 2019 
Copyright by Elizabeth K. Liebschutz-Roettger

All Rights Reserved 

EDUCATION ABROAD PARTICIPATION: PREDICTING PARTICIPATION THROUGH HIGH SCHOOL ACADEMIC RECORD AND INTENT TO BE INVOLVED AS REPORTED IN THE FRESHMAN SURVEY AND IN THE COLLEGE SENIOR SURVEY (CSS)

by

Elizabeth Karen Liebschutz-Roettger

MS, (2012), University of Kentucky

MA, (2004), DePaul University

BA, (2000), Lake Forest College

A Dissertation Approved on

November 20, 2019

by the following Dissertation Committee:

Dr. Amy Hirschy, Dissertation Chair

Dr. Jeff Valentine

Dr. Michael Cuyjet

Dr. Jacob Gross 


\section{DEDICATION}

I would like to dedicate my dissertation to my sons Davis and Max. When I started the $\mathrm{PhD}$ process, it was for me, but I finish for you. I hope my perseverance teaches you about setting and accomplishing goals, small sacrifices for long-term gains, and that hard work is key to success. It was a great challenge to be away from you as babies and young children for graduate studies and dissertation writing, but it was a necessity to invest in bettering myself. To Bart, for your patience through the entire journey, eventually learning that calling my dissertation a "paper" was not a good idea, and bestowing upon me the name Doc Louisville; which meant I had no choice but to finish my degree. To my sister, Ann Liebschutz, who always shook her head at me throughout the process. To my brother, Rob Liebschutz, and sister-in-law, LeaAnne DeRigne, who both survived their own terminal degrees, dissertation processes, and provided continual encouragement from afar. Per usual, my parents, Pat and David Liebschutz went along with my latest idea ("I think I am going to get my PhD") providing lots of conversation and support. And now I get to join my late father, Dr. David Liebschutz, as a UofL alum. Go Cards! 


\section{ACKNOWLEDGMENTS}

I would like to acknowledge the time and patience of Dr. Amy Hirschy and Dr. Jeff Valentine in the marathon (or perhaps an ultra-marathon) that has been the dissertation journey for me. You have spent time talking me up or down; but you continued to talk and encourage; which has led to the completion of the process. I am grateful for all you have given. Thank you.

Thank you to Dr. Michael Cuyjet who helped me transition into my PhD program at the University of Louisville and providing guidance and insight. I appreciate the role Dr. Jacob Gross has provided in early conversations as I developed my ideas on my dissertation and data. I thank both of you for your willingness to serve on my committee and staying with me through the process.

I must also take the time to thank my colleagues in the College of Business at the University of Louisville who have provided continual support as I completed my degree. I am grateful for the support of Dolores Calebs, Allie Goatley, Jane Goldstein, Kaitie Siers, Katie Etheridge, Laurie Anne Roberts, and Dr. Robert Taylor. 


\begin{abstract}
EDUCATION ABROAD PARTICIPATION: PREDICTING PARTICIPATION THROUGH HIGH SCHOOL ACADEMIC RECORD AND INTENT TO BE INVOLVED AS REPORTED IN THE FRESHMAN SURVEY AND IN THE COLLEGE SENIOR SURVEY (CSS)

Elizabeth K. Liebschutz-Roettger
\end{abstract}

November 20, 2019

Globalization is a topic of great interest in higher education yet fewer than $10 \%$ of college graduates participate in a formal study abroad program. While according to The American Council on Education [ACE] (2008) data, nearly 80\% of incoming first-year students intend to go abroad, the reality is most students do not. Practitioners in Education Abroad (EA) are continually looking at ways to help increase student participation in overseas programs and opportunities. The study looks at frequencies and predictor models to help determine factors that influence student participation in study abroad. The study utilized HERI's 2009 The Freshman Survey (TFS) and 2013 The College Senior Survey (CSS). The student responses were matched and used predictor variables pertaining to the student characteristics (sex, race/ethnicity, academic major), post-secondary school characteristics (public vs. private), intent to go abroad, high school academic performance (GPA, AP courses, and college entrance exam scores), intent to go abroad, and intent to be involved in college (join student government, NCAA/NAIA athletics, join a fraternity or sorority, participate in club/IM sports, participate in student 
clubs and organizations, and faculty research) to examine actual participation in study abroad. Study results indicate that White students are 1.2 times more likely to go abroad than non-White students, Humanities majors are 1.5 more times likely to go abroad than other majors, and that students who attend a private, post-secondary schools are 2.5 more times likely to go abroad their public post-secondary school counterparts. First-year students who intend to go abroad are 2.5 times more likely to go abroad than their peers who do not. College entrance exam scores, GPA, and AP courses taken are all positively associated with going abroad. Student involvement in on-campus activities predict education abroad participation at differing rates. All variables in the model predict $70 \%$ of education abroad participation. The study demonstrates that predominantly White, female, students are private colleges and universities are more likely to go abroad. However, intent to be involved as a first-year student can be a predictor for education abroad participation, dependent on what the involvement is. 
TABLE OF CONTENTS

PAGE

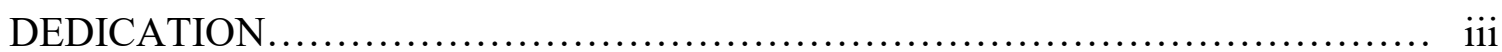

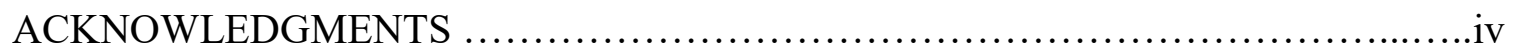

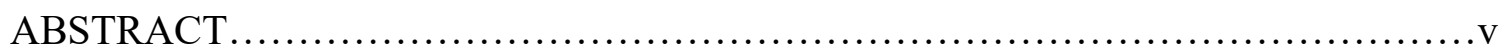

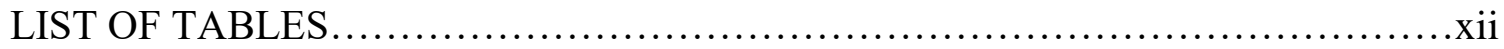

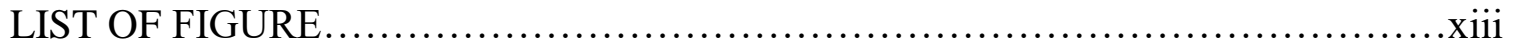

CHAPTER

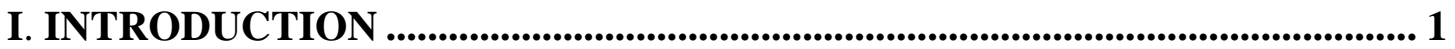

Education Abroad and Higher Education.............................................................. 1

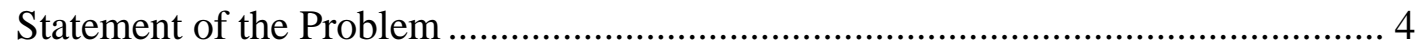

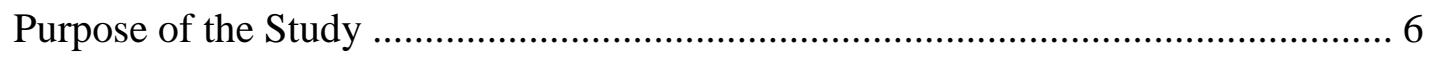

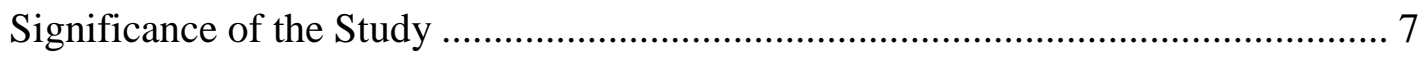

Conceptual Framework ………………………………................................. 11

Research Questions and Hypotheses ..................................................................... 12

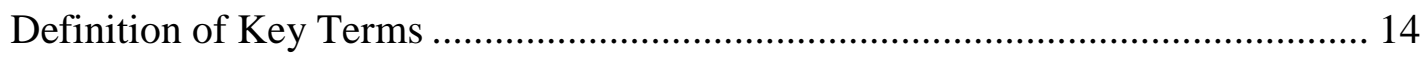

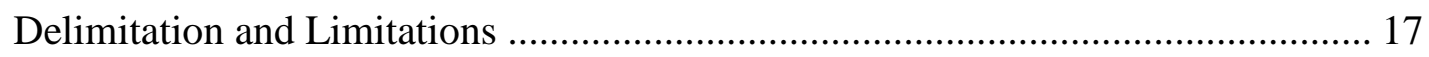

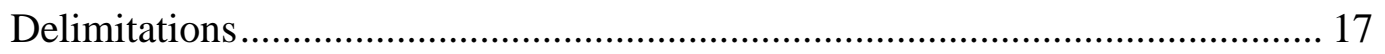

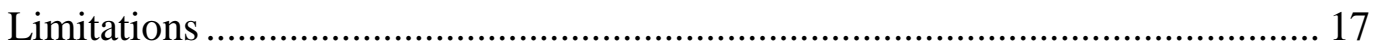

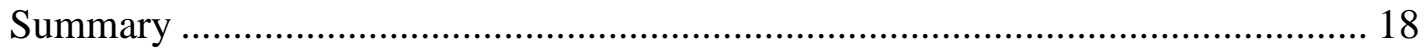


CHAPTER PAGE

II. REVIEW OF THE LITERATURE.......................................................... 20

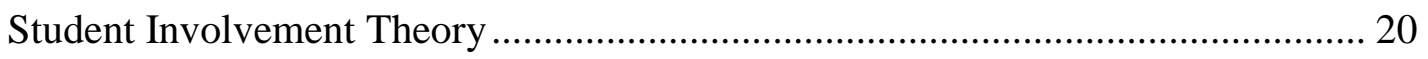

High-Impact Experience Programs ............................................................. 24

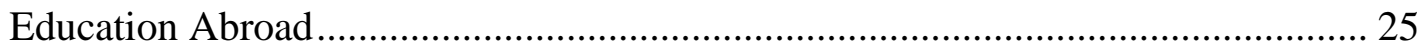

Brief History of Education Abroad ................................................................. 26

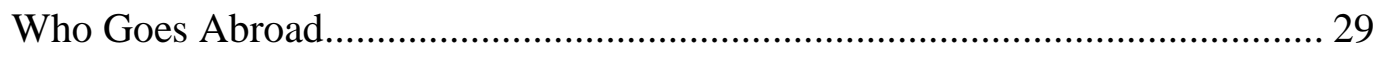

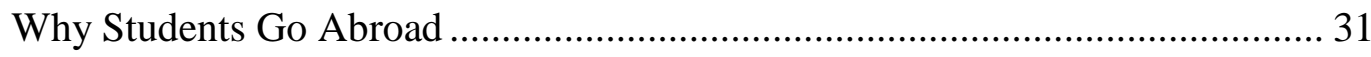

Education Abroad Research................................................................... 33

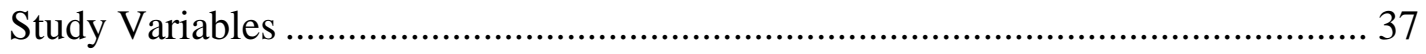

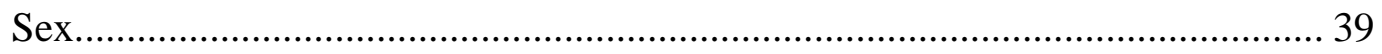

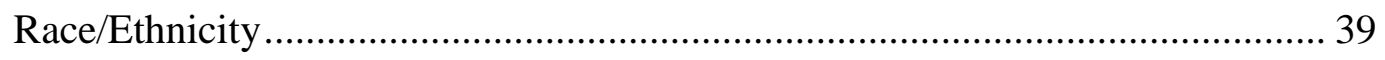

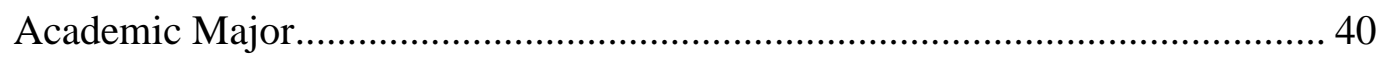

Post-secondary School Characteristics..................................41

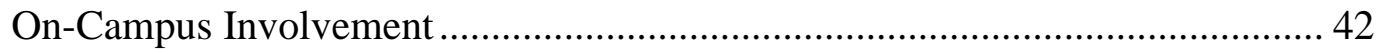

High School Academics and Test Scores ................................................... 42

Cooperative Institutional Research Program (CIRP) ..................................... 43

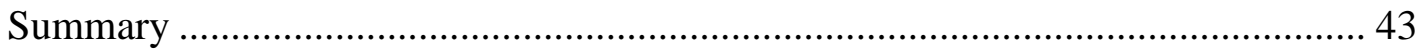


CHAPTER $\quad$ PAGE

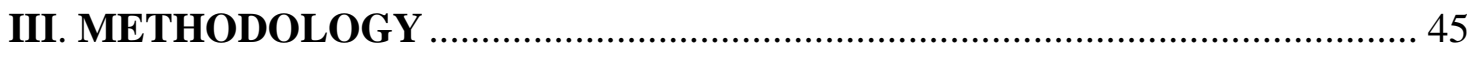

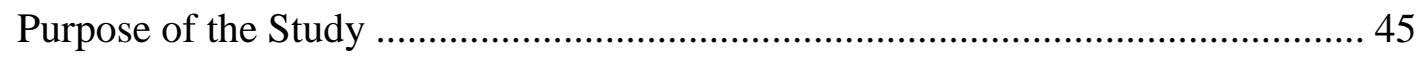

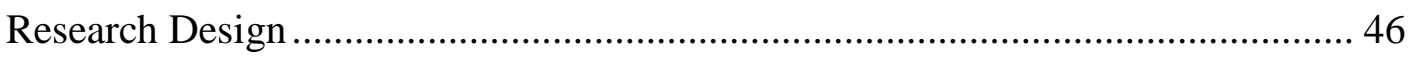

Study Sample

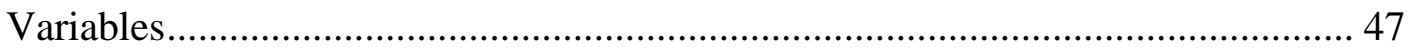

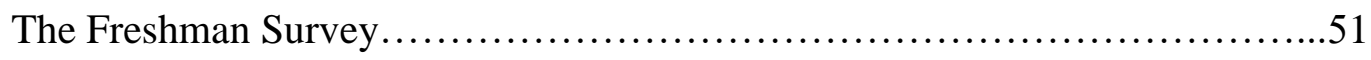

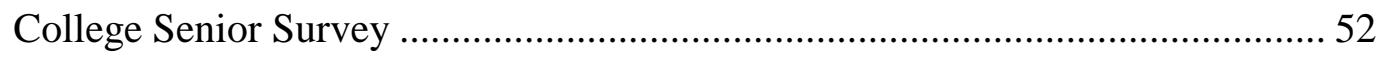

The National Survey on Student Engagement ................................................... 53

Research Questions and Analyses ....................................................................... 53

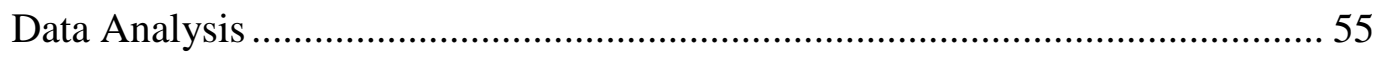

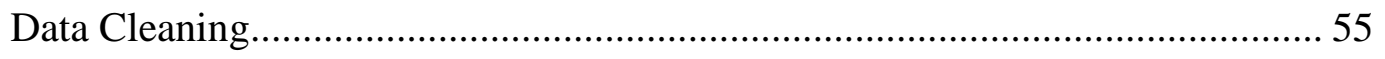

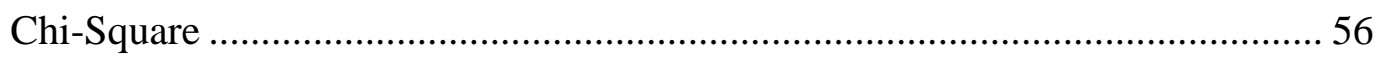

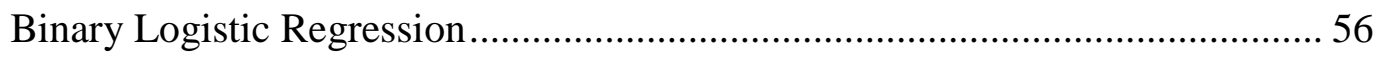

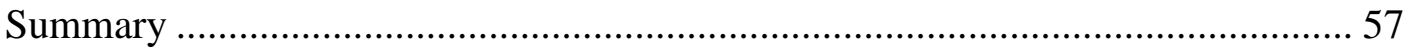

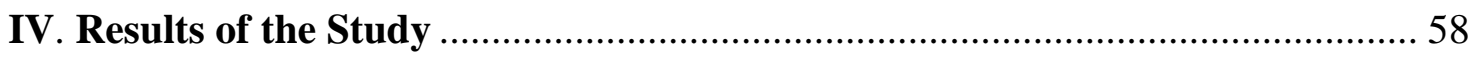

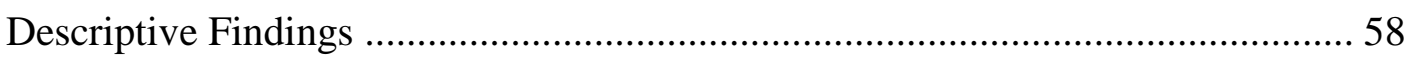

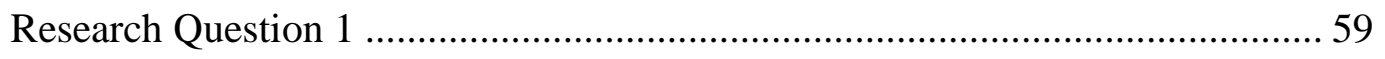


CHAPTER $\quad$ PAGE

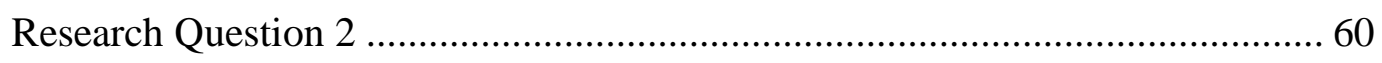

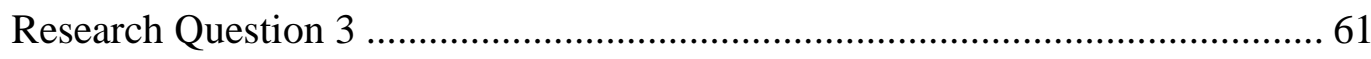

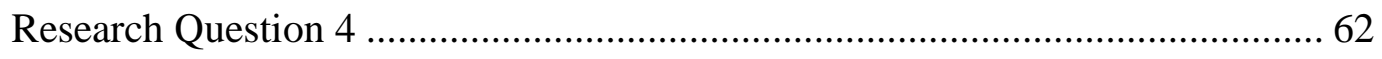

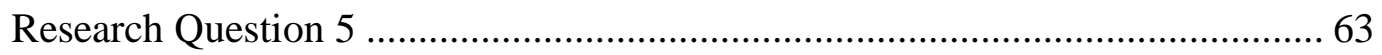

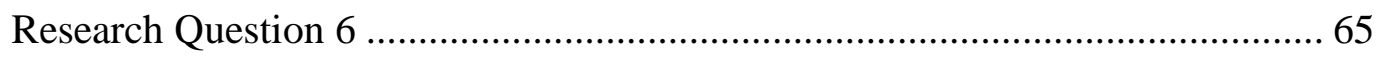

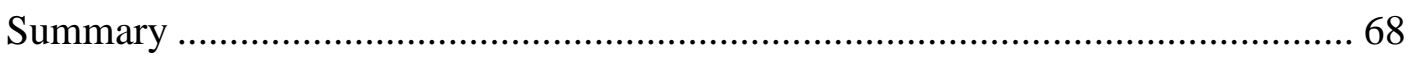

V. DISCUSSION, FUTURE DIRECTIONS, AND CONCLUSION ..................... 70

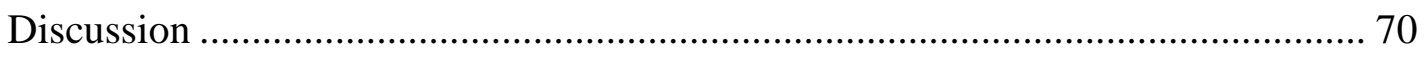

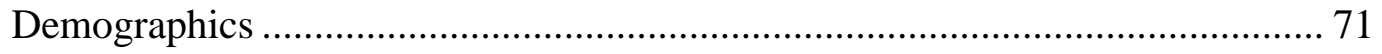

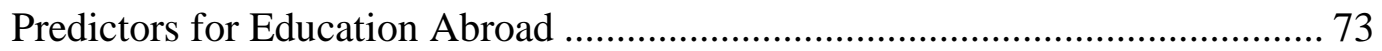

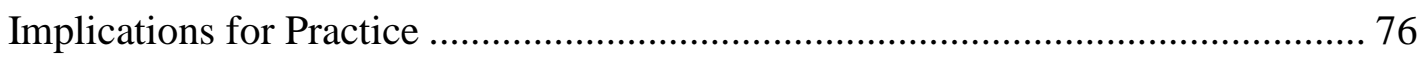

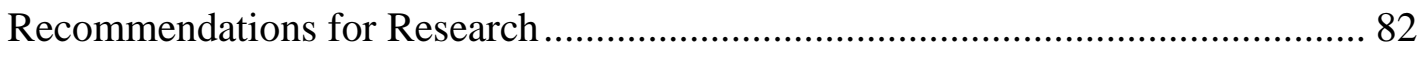

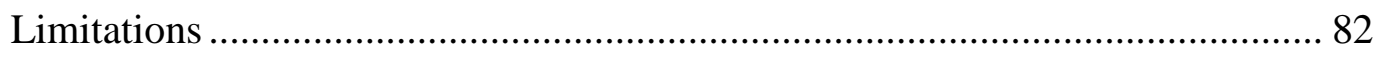

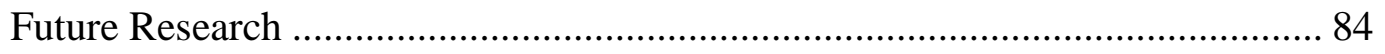

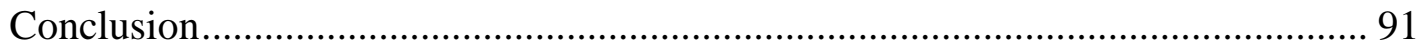

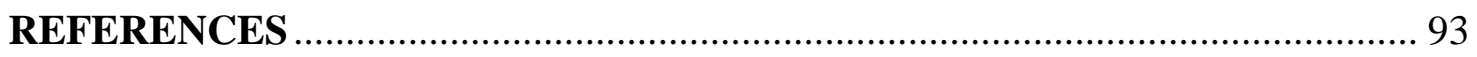

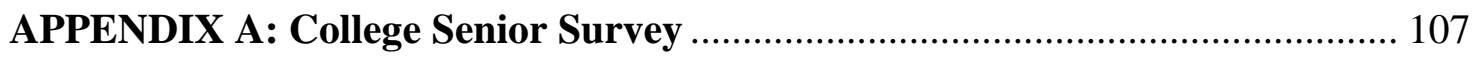




\section{TABLE OF CONTENTS--Continued}

CHAPTER

PAGE

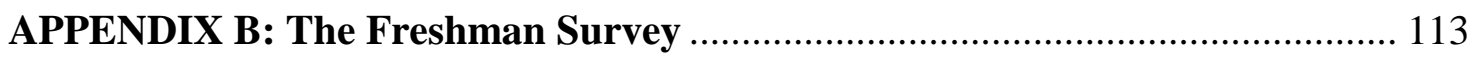

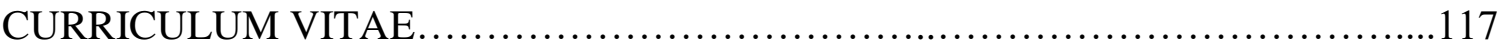




\section{LIST OF TABLES}

TABLE

PAGE

1. Description of the Study Variables Per the TFS and CSS Surveys.................48

2. Recoding of Study Variables.........................................49

3. Statistical Analysis Used in the Study..................................55

4. Percentage Table for Student and Post-secondary School Characteristics.........59

5. EA Participation within Sex, Race/Ethnicity, Academic Major, and Postsecondary School Characteristics......................................60

6. EA Participation within Post-secondary School Characteristics.................61

7. EA Participation for Intent to Study Abroad Based on TFS Survey and Actual Participation

8. Logistic Regression Results: Intent to Study Abroad as a Predictor of Actual

Participation

9. Logistic Regression Results of High School Academic Characteristics as Predictor of Participation in Study Abroad

10. Logistic Regression Results: Intent to be Involved in Campus Student Activities as a Predictor of Actual Participation in Study Abroad. .65

11. Logistic Regression Results: Variables which are the Best Predictors for Study Abroad Participation. .67 


\section{LIST OF FIGURE}

$\begin{array}{lll}\text { FIGURE PAGE } & \text { PAR }\end{array}$

1. Astin input-outcomes with study variables ...............................46 


\section{CHAPTER I}

\section{INTRODUCTION}

\section{Education Abroad and Higher Education}

Participation in education abroad (EA) prepares college students, "for life in an increasingly globalized world" (Dolby, 2004, p. 153). In 2008 the Association of International Educators (NAFSA)'s annual conference themes emphasized that international educators' need to continue to expand opportunities that create global citizens (McMurtrie \& Fischer, 2008). EA refers to the time students spend studying, interning, or participating in service learning outside the United States (Forum on Education Abroad, 2011). Increasingly, colleges and universities include global intentions in their mission and vision statements to help promote their intentions of having globally minded, culturally sensitive graduates. Most colleges and universities include phrasing in their goals and mission statements regarding the importance of learning about other cultures (Hopkins, 1999). One aspect in developing the globalized experiences of students is through EA. While international curricula and faculty are meaningful for students, the experience of going abroad is more important for students (Love \& Estanek, 2004). In EA, the actual participation numbers are increasing yet the percentage of students going abroad has not changed due to the overall changes in undergraduate enrollments (The Power of Internationalization [IIE], 2015).

Globalization is increasingly important in the world as government, industry, and higher education leaders expect graduates to meet the demands of a culturally diverse 
workforce (Lincoln Commission, 2005; The Senator Paul Simon Study Abroad

Foundation Act, 2013). Globalization reaches into higher education and is highlighted by the increased flexibility created when faculty and students participate in international education and are not bound by brick and mortar locations (Hudzik, 2011). Hudzik (2011) defines comprehensive internationalization as a "commitment, confirmed through action to infuse international and comparative perspectives throughout the teaching, research, and service missions of higher education" (p. 10). Internationalization is viewed as the countries around the world and how they interact individually (Daly, 1999). Many companies and organizations are now multinational and want graduates prepared to work and function in a continually changing international environment (Jaschik, 2015). With the need for an internationally diverse and culturally rich workforce, colleges and universities must prepare their students to meet the needs and expectations of employers. Internationalization in higher education refers to the changes made to the curriculum on the home campus including international faculty and courses with international topics (DeWit, 2009; Knight, 2014).

In relation to the internationalization, globalization is an economic concept (Daly, 1999). The theories of globalization bring together all the trade economies into one entity. However, in higher education, globalization in education means to integrate learning, culture, and economy as a means of trade (Knight, 2014). Globalization of higher education is meant to assimilate the learning from a dynamic perspective (Daly, 1999; Knight, 2014) whereas internationalization tends to only happen at a student's home college or university (Daly, 1999). 
EA brings a form of diplomacy to a younger generation giving them greater access to the world. With increased exposure, it is the students' responsibility to understand how cultures vary from their own. A globalized society requires our students to know how to interact culturally, professionally, and personally with others from a wide variety of backgrounds. Another factor to motivate American college graduates to spend time abroad is the need to ensure they are staying competitive with their international counterparts. Many international colleges and universities, especially in disciplines such as business, require their students to spend time abroad as part of their studies. Students from the United States should be equally prepared.

The changes in the world emphasize the value of globalization. As technology and communication make other parts of the world more accessible, economies become more intertwined, and there are flexible boundaries between countries and cultures, graduates of colleges and universities must prepare to function in an ever-changing society. Campus life is becoming more diverse as more international students, immigrants, and refugees attend colleges and universities in the U.S. (IIE, 2015; Spring 2015). Domestic students need to understand how to interact with and appreciate global differences. In higher education, globalization extends beyond what faculty and students bring to the campus, but it also encompasses sending them away for a better understanding of the interconnectedness of cultures and lifestyles around the world (Love \& Estanek, 2004).

Higher education leaders embrace the notion of globalization expressed in institutional mission statements in various manners (Merrill, Braskamp, \& Braskamp, 2012). Some initiatives used to "internationalize" the curriculum include the introduction 
of global components to courses and degree requirements, the hiring of more international faculty, and recruiting more international students to campus (Ward, 2015). More campuses focus on globalization through worldwide travel programs such as study abroad, international service learning, faculty-led programs, and internships abroad (IIE, 2015; Twombly et al., 2012; Ward, 2015).

Research in EA is saturated in some areas while still emerging in others. EA research is well-documented in language acquisition (Brecht, Davidson, \& Ginsberg, 1995; Engle \& Engle, 2004; Freed, 1995; Huebner, 1995) and intercultural development (Anderson, Lawson, Rexiesen, \& Hubbard, 2006; Carlson \& Widaman, 1988). However, area developing in emerging research interest is EA and student persistence and degree completion (Hamir, 2011; IU News Room, 2009; Malmgren \& Galvin, 2008; Sutton \& Rubin, 2010; Young, 2008). It is important for EA research to move beyond the historical research foci (cultural and language development, etc.) and examine the relationship of an EA to the entire student experience. The research related to EA needs to evolve to provide a better understanding about the potential mutual benefits to both the student and the institution. The research in this study will contribute to the knowledge base and understanding of the influence of EA and student involvement on-campus.

\section{Statement of the Problem}

According to data available from the IIE (2015), 304,467 students participated in EA in the 2013-2014 academic year. The number is a 5.2\% increase from the previous year, but only accounts for less than $10 \%$ of the total undergraduate student population (IIE, 2015). The low participation rate raises concern since research suggests EA participation is associated with increased persistence rates and on-time graduation, especially for students of color and first-generation students (Hamir, 2011; Malmgren \& 
Galvin, 2008; Sutton \& Rubin, 2010). Despite the findings in EA research, the majority of today's participants are White (76.3\%), female (65.3\%) students from private college and universities, and from middle- to upper-class economic statuses (IIE, 2015; Twombly, Salisbury, Tumanut, \& Klute, 2012).

While more women currently participate in study abroad, international travel and studies historically prepared men for worldly careers (Hoffa, 2007). One possible explanation for the increase in female participation in overseas programs is that women see the time in college as a period where they are unencumbered and feel they will not have the freedom or flexibility for travel in the future (Rouse, 2013). Unlike their female peers, many college men believe an international "adventure" is possible at any time in their lives (Rouse, 2013). There is student concern that time abroad will influence their involvement on-campus. Many students, and particularly male students, believe they need to take advantage of the opportunities present on-campus. Some students perceive that time abroad will detract from their on-campus experiences, especially in terms of leadership and involvement (Duzny, 2014; Rogers, 2014; Rouse, 2013).

The body of research related to EA continues to expand into areas outside of cultural acquisition and language development. In their work Student Success in College: Creating Conditions That Matter, Kuh et al. (2005) discuss the importance of study abroad participation as an attribute of student success. More recent research focuses on student persistence (Hamir, 2011; Sutton \& Rubin, 2010). Hamir's (2011) research focuses on a single institution and Sutton and Rubin's (2010) examines an entire state system. The research in the current study utilizes a national data set, thus looks at a larger population of EA participants. For the students who participate in study abroad, 
their international experience is part of their overall development as a college student, much like their student involvement in on-campus activities and academics (Kuh, 2008). A past-participant study conducted by Institute for the International Education of Students [IES] (2002) reports that EA participants express greater self-confidence, skills that are more applicable to the work force, greater understanding for others' values and cultures, and increased maturity. The benefits of participating in EA are welldocumented in existing research, as are the advantages of being involved on-campus (Astin, 1985a; Astin, 1985b; Kuh, 2008). This study examines the relationship between to EA and student involvement on-campus, looking more precisely at whether on-campus involvement impedes EA given participants are required to disrupt their time on-campus.

\section{Purpose of the Study}

The purpose of the study is to determine whether there exists a significant difference in students' intent to go abroad and actual participation, and what factors might predict participation. The study will also look at the student characteristics, postsecondary school characteristics (public versus private), intent to go abroad, academic characteristics, and their intent to be involved in college per The Freshman Survey (TFS); which Salisbury, Umbach, Paulsen, and Pascarella (2008) believe influences intent to study abroad. Participation in activities is a strong predictor of student success and persistence to graduation (Astin, 1977; Astin, 1984; Kuh, 2007; Kuh et al., 2005).

As previously noted, EA has low participation rates across the United States despite research indicating positive effects on students' college experience, especially persistence (Hamir, 2011; Sutton \& Rubin, 2010). EA research (Hamir, 2011; Sutton \& Rubin, 2010) suggests participation increases student persistence due to academic focus and, for summer participants, the opportunity to add additional hours to their yearly 
curriculum. Despite the known benefits of EA as reported in blog posts, student-written articles, professional conversations, and an institutional survey, some students report they are unwilling to go abroad during their college experience because it would prevent them from participating in activities, leadership opportunities, and other on-campus experiences (Duzny, 2014; Rogers, 2014). Some students believe in order to go abroad they most forego an on-time graduation, participation in internships, assuming leadership opportunities on-campus, or involvement in athletics (Duzny, 2014; Rogers, 2014; Rouse, 2013). The proposed study aims to explore students' intent to go abroad and actual participation. The differences will be determined based on responses to The Freshman Survey (TFS) 2009 and the corresponding 2013 College Senior Survey (CSS), which is housed within the Higher Education Research Institute (HERI). The investigation will examine self-reported student responses to questions pertaining intent to go abroad (TFS), actual participation in a program (CSS), high school academic achievements (TFS), intent to be involved in college (TFS), post-secondary school characteristics (public vs private), and personal characteristics (sex, race/ethnicity, major, socioeconomic status) as they relate to EA participation.

\section{Significance of the Study}

The proposed study builds on the existing EA literature. While language and cultural development are important, it is becoming increasingly more common for students who study abroad to not study a foreign language (IIE, 2015), which is apparent in IIE's report (2015) of 12.6\% of EA participants studying in the United Kingdom. According to IIE Open Doors data (2015), only 7.8\% of EA in 2013-2014 was specifically for foreign language study while almost $61 \%$ was for STEM, social sciences, and business. 
Given the research on students' participation in educational enriching experiences such as service learning (Astin \& Sax, 1998; Pascarella \& Terenzini, 2005; Webber, Krylow, \& Zhang, 2013) and co-ops/internships (Miller, Rycek, \& Friston, 2011; Nesheim et al., 2007), the need continues for more research on the relationship of EA and on-campus student involvement. Existing research suggests successful campus life integration includes students who actively participate on-campus in areas such as student organizations, leadership development, academic research, and living on-campus that are engaging in high-impact experiences (Kuh et al., 2005; Kuh, 2008; Pascarella \& Terenzini, 2005). High-impact educational experiences refer to the complementary learning opportunities inside and outside classrooms that augment the academic program (Kezar \& Kinzie, 2006). EA is a co-curricular part of education similar to other forms of high-impact experiences, thus time abroad is creating a greater collegiate experience for students.

However, unlike some co-ops/internship, EA requires students to have a significant interruption from their life on-campus. An administrator observes "it's interesting that what takes students away from campus makes the Wofford [College] experience what it is" (Kuh et al., 2005, pp. 226-227). Kuh et al. (2005) indicate the benefits of EA by pointing out that students who go abroad "bring their experiences and learning back to campus, thereby enriching the learning environments for their peers" ( $p$. 227). The design of this study examines the choice to spend time abroad as it relates to involvement on-campus. Overall, EA practitioners and researchers in education abroad want to continue to better understand the value of the experience of the time abroad (Dwyer, 2004; Fischer, 2009; McCabe, 2001), the makeup of the students who participate 
(Salisbury, Paulsen, \& Pascarella, 2010), and the influence of going abroad as a part of their total collegiate experience (Kitsantas, 2004; Metzger, 2006; Paige, Fry, Stallman, Josic, \& Jon, 2009; Sternberg, 2002). The results from the study may provide more information about the collegiate experience as it relates to student involvement and selfreported EA participation.

Groups external to higher education are attentive to college student participation in international experiences. Government organizations such as the U.S. Department of State, the Commission on Abraham Lincoln Study Abroad Fellowship Program, and the Senator Paul Simon Act (Lane-Toomey, 2014; Lincoln Commission, 2005; Senator Paul Simon Act, 2013) as well as colleges and universities are interested in the overall influence of EA due to the potential diplomatic influence it can promote. In the post-9/11 world, many government entities need a work force with linguistic and cultural knowledge of countries outside of the U.S. and comfort with international travel. Much of the focus in student international experiences relates to diplomatic matters, while others are interested from a perspective of national security.

EA offers many benefits to students including decreased time to graduation and increased student persistence, especially for underserved populations (Hamir, 2011; Sutton \& Rubin 2010). Continued research centered on EA provides greater insight about the overall student experience. As mentioned, much of the current research focuses on the cultural immersion (Anderson, Lawson, Rexiesen, \& Hubbard, 2006; Carlson \& Widaman, 1988), language acquisition (Brecht, Davidson, \& Ginsberg, 1995; Engle \& Engle, 2004; Freed, 1995; Huebner, 1995), and positive effects on student persistence (Hamir, 2011; Sutton \& Rubin, 2010). The design of this study considers participation in 
EA in college as determined by student characteristics, post-secondary school characteristics, intent to go abroad, academic characteristics, and intent to be involved as reported by TFS and CSS data.

According to a 2008 American Council on Education (ACE) report on collegebound students' interests in international programs, 55\% indicated they are likely to spend time abroad while in college. The ACE data are a startling contrast to the numbers stated in IIE's Open Door Report representing the 2013-2014 academic year that indicates less than $10 \%$ of students with bachelor's degrees participated in an international program, with the majority $(62.1 \%)$ going abroad for eight weeks or less (IIE, 2015). In the same 2008 ACE report, 32\% of students indicated uncertainty/no interest in EA at the collegiate level. While the most commonly stated reasons are costs and language proficiency, $13 \%$ reported concerns an EA experience would interfere with their extracurricular, sport, and social life on-campus. One obstacle deterring students from going abroad is Fear of Missing Out ("FOMO”) (Duzny, 2014; Rogers, 2014; Rouse, 2013). No existing study examines intent to be involved as a predictor of education abroad participation. The benefit of continued EA research is greater understanding of whether the students' concerns are founded. This study provides a better understanding about the relationship between participation in an overseas program and student involvement intent. 


\section{Conceptual Framework}

Astin provided the theoretical framework for the study with his research on student involvement on campus in activities and academics. Astin's theory of student involvement focuses on the psychological and physical energy a student dedicates to their academic experience (Astin, 1984). The academic experience encompasses more than just the classroom and considers what a student chooses to be involved in on campus. From Greek Life, to faculty research, to classroom participation, Astin's Student Involvement Theory includes the whole student experience. Astin $(1984,1999)$ theorizes involvement is the observable behavioral component of the psychology of motivation.

Astin's $(1984,1999)$ work led him to better understand the effectiveness of colleges and universities. In working with the National Merit Scholarship Cooperation, Astin conducted research that generated a new awareness into aspects of college success. His model of research focused on the Input-Environment-Outcomes (I-E-O); he looked at how research could be broken down by utilizing the various components of the I-E-O model.

While often called value-added research in economics research, Astin and Antonio (Astin \& Antonio, 2012) prefer to utilize talent-development in referring to input-outcomes research as it embraces what is trying to be achieved in educational

research. Astin and Antonio (2012) explain that outcomes (also referred to by Astin as outputs) describes, "the 'talents' we are trying to develop in our educational program, input refers to those personal qualities the student brings initially to the educational program (including the student's initial level of developed talent at the time of entry)" 
(p. 19). Astin and Antonio (2012) also refer to pretest-posttest, value added, and longitudinal as other forms of input-outcomes studies.

The most pertinent aspects of input-outcomes research are that it focuses on the long-term changes that occur over a period of time and considers the change based on incoming characteristics (Astin \& Antonio, 2012). Long term data from a talentdevelopment inputs-outputs study provides information to faculty and practitioners in higher education to create interventions earlier in a student's tenure in college.

\section{Research Questions and Hypotheses}

To better understand student involvement and education abroad, the proposed study aims to investigate the following research questions:

1. What is the relationship between the student background characteristics reported on TFS and participation in study abroad as reported on the CSS?

$\mathrm{H}_{1}$ : The background characteristics of students who study abroad are different than those who do not study abroad in their sex, racial/ethnic identity, and academic major.

Research from IIE data (2015) report students who go abroad are more likely to be female, and White. While current IIE data reports an increase in business and STEM majors going abroad, historically the students studying humanities were more likely to go abroad.

2. Do students attending public and private colleges and universities participate in study abroad at similar rates?

$\mathrm{H}_{2}$ : The post-secondary school characteristics which have higher percentage of students who participate in study abroad differ by type of school. 
Historically (IIE, 2015) students participating in EA programs were more likely to attend a private college or university.

3. Is intention to study abroad as a first-year student related to actual participation in study abroad?

$\mathrm{H}_{3}$ : Students who intend to go abroad are more likely to participate in study abroad.

ACE (2008) data indicate there is a sharp decline in the number of students who intend to go abroad and actually end up participating in an education abroad program.

4. Does a students' personal high school academic performance (standardized college entrance exams, GPA, AP courses, and AP exams) predict involvement in study abroad?

$\mathrm{H}_{4}$ : High school academic outcomes and characteristics (GPA, standardized college entrance exams, AP courses, and AP exams) predict which students intend to participate in EA.

Students who are more successful in high school (Adelman, 2006) are typically going to be more motivated in the early part of their college academic careers, and thus more likely to go abroad (Martin, Wilson, Liem, \& Ginns, 2013).

5. Does intent to be involved in college activities predict study abroad participation? $\mathrm{H}_{5}$ : Students who intend to be involved in college are more likely to go abroad than those who do not.

Astin's $(1984,1999)$ work on student motivation supports the idea that students who intend to be more involved in college are more likely to participate in activities of student engagement of which study abroad is one. 
6. Of the variables collected on The Freshman Survey, what are the best predictors of participation in study abroad?

$\mathrm{H}_{7}$ : Student intent to go abroad, intended major, gender, and sex/ethnicity will be the strongest predictors of student participation in study abroad. Whether it is IIE data (2015) on the demographics of American study abroad participation or the various research articles (ACE, 2008; BaileyShea, 2009; Dwyer \& Peters, 2004; Hopkins, 1999; Kuh, 2008; Miller, Rycek, \& Frister, 2011; Dhanatya, Futuro, \& Kheillan, 2008; and Rogers 2008) which cite differing factors which influence student study abroad, the TFS and CSS data provide a different snapshot which helps provide more information about student participation in study abroad.

\section{Definition of Key Terms}

The following key terms provide the reader with a more precise definition of the important aspects of the study:

1. Academic Major is the area of study a student pursues while enrolled in a college or university and is self-reported on The Freshman Survey (TFS).

2. Involvement refers to the number of activities in which a student participates including on-campus student organizations, leadership development, and academic research projects as reported as intent to participate on The Freshman Survey (TFS) and actual self-reported participation on the College Senior Survey (CSS) as well as their academic and extracurricular participation in high school. 
Astin's theory of Student Involvement includes the development of a student in relation to their co-curricular commitments (Astin, 1985a).

3. Campus Involvement Opportunities is what a college or university makes available for their students in order to create community and encourage greater connection between the students and the campus.

4. College Senior Survey (CSS) is an instrument administered to students in their final year of undergraduate studies at participating college and universities. Designed by the Higher Education Research Institute (HERI) based at UCLA, the purpose of the study is to examine student participation in on-campus involvement in student activities and research. Colleges and universities pay to administer the CSS to their students.

5. The Freshman Survey (TFS) is an instrument administered to students in their first semester of undergraduate studies at participating colleges and universities who pay to use the TFS. Designed by the Higher Education Research Institute (HERI) based at UCLA, the purpose of the study is to examine student intent to participate in on-campus involvement in student activities and research as well understand more about the characteristics students bring with them when they come to college.

6. Education Abroad (EA) is an educational experience outside the U.S. borders in which students engage as an experience for academic credit, service learning, 
volunteering, and/or noncredit internship/co-op (Forum on Education Abroad, 2011). EA does not include study within the U.S.

7. Globalization is the flexible exchange of thoughts, education, people, ideals, enterprise, market, and data throughout various countries and cultures (Knight, 2004). Globalization is the exchange of ideas, learning, culture, and economy with the intention of integrating education (Daly, 1999; Knight, 2014).

8. Race/Ethnicity refers to categories that people identify or belong to according to the community but does not have biological or anthropological foundations (IPEDS, 2014). Harley, Jolivette, McCormick, and Tice (2002) indicate race is political in nature and has evolved into an "intersection of both biological and cultural heritage" (p. 220). Although sometimes considered synonymous, ethnicity embraces "the national, regional, or tribal origins of one's remembered ancestors and the customs, traditions, and rituals (i.e., subjective culture) handed down by these ancestors, which ethnic group members, are considered to be their culture" (Helms \& Cook, 1999, p. 19).

9. Sex is one's biological identity based on the designation of male or female in relation to indicators such as sex chromosomes, gonads, internal reproductive organs, and external genitalia (APA, 2011). The CSS 2013 utilizes a dichotomous variable of male and female (CSS, 2013).

10. Student Involvement is the amount of "physical and psychological energy that the students devote to the academic experience" (Astin, 1985a, p. 134). The academic experience includes time in-class and engaging with faculty members, as well as what the student does outside of class. The academic experience 
includes high-impact experiences such as academics, research, participation in clubs and organizations on-campus, and campus athletic programs.

\section{Delimitation and Limitations}

The following sections will explain the delimitations and limitations of the present study. The delimitations are the researcher's established boundaries in the study. The limitations account for the aspects of the study the researcher cannot control.

\section{Delimitations}

The study is limited to the 2013 CSS/ 2009 TFS matched data. The data are collected from colleges and universities who pay to administer the assessments to their students. The sample population is the randomly selected students at four-year colleges and universities who responded to the CSS survey in 2013 with corresponding TFS 2009.

\section{Limitations}

As with all research, there are several limitations to the study. The CSS and TFS surveys do not provide a definition of EA to student respondents. Thus, the data rely on the students' definition of "study abroad" when answering the question. The data also do not provide information about the duration of students' EA experience, of interest to many EA practitioners. There is also a lack of information about when students are abroad, destinations, and other unique details of interest in study abroad research since they can differentiate a student's experience. Involved students may also be more likely to respond to a survey, such as the TFS and CSS, sent to them by their college or university. Therefore, those students who responded to the survey may not be representative of those students who opted not to respond. And while a student's financial background is of interest in EA research, since finances appear to be a barrier to going abroad, the CSS and TFS do not have a student designate if they are a Pell grant 
eligible student; therefore, these surveys do not provide this information of interest to EA practitioners.

The use of a 2013 survey is also a limitation to the study. More recent versions of the TFS and CSS provide more detailed information about student gender identity and sexual orientation but are not yet available. Gender and sexual identity are of interest in the field of EA as a means to better serve and provide opportunities for all students. The 2015 version of the CSS also further divides questions about student involvement into areas of academic involvement and co-curricular experiences rather than collapsing them into a single question. The survey responses are limited to randomly selected students at colleges and universities which pay to administer the TFS and CSS. The use of a nationwide data set provides more generalizable results but may be less applicable to individual post-secondary schools (ACE, 2008; Adelman, 2004). The results are not applicable to two-year colleges and universities, which is also another area of EA research.

Despite the limitations to the research, this study provides a new vantage point into the factors that influence or deter participation in EA. In addition, the study examines High-Impact Experiential Programs (HIPs), particularly valuable to the field of EA research. Another benefit to the study is creating a better understanding of students who go abroad through the results provided by the CSS data.

\section{Summary}

In order to achieve the goals of globalization, it is important to examine potential barriers to EA including many of the valuable experiences students may have on campus. The next few chapters will expand on the study. Chapter two provides an overview of the theoretical background and model for the study along with the characteristics of EA participants, variables of the study, and a brief history of EA. The third chapter will 
outline the methodology utilized for the study. In the fourth chapter, the results will be presented. The final chapter discusses the results of the study as they relate to the current body of research and implications for practice and future research. 


\section{CHAPTER II}

\section{REVIEW OF THE LITERATURE}

The study examined the relationship between student characteristics, postsecondary school characteristics, intent to go abroad, high school academic characteristics, and intent to be involved in college and their participation in education abroad (EA). The chapter is divided into two sections with the first focusing on Astin's Theory of Involvement and Kuh's High Impact Experiences Programs (HIP). Astin's Student Involvement Theory is the conceptual theory supporting the study and defines aspects of involvement included in the study while Kuh's HIPs provides more information on specific types of on-campus involvement. The second part of the chapter focuses on Education Abroad. The chapter provides an historical overview, information about who goes abroad and why, and existing research related to EA.

\section{Student Involvement Theory}

The value of students' education is determined in part by their personal commitment (Webber, Krylow, \& Zhang, 2013). With greater investments made by students into their college experience, comes a greater connection to their college or university. The investment is their involvement including academic commitments, engaging their peers, student organizations, and on-campus work (Astin, 1985a). Therefore, colleges and universities need to create opportunities for increased involvement to allow students to become purposefully involved in their collegiate experience. The benefit to the colleges and universities is increased graduation rates, and 
for the students, increased persistence rates and a better overall college experience (Rust, Dhanatya, Futuro, \& Kheiltash, 2008; Tinto, 1993).

Students' connection to their college or university is integral to Astin's student involvement theory (Astin, 1985b; Astin \& Antongli, 2012). In the late 60s and 70s, Astin's work investigated student involvement within a college or university based on trying to determine why students persisted or dropped out of college. Astin's widereaching research on involvement includes a variety of aspects of the college experience including faculty-student interactions, employment, residence during college, and hedonism $(1977,1984,1985 b)$. In furthering the definition of student involvement Astin $(1984,1985 b)$ highlights the physical and psychological exertions a student invests in their college experience. Astin $(1977,1984)$ states student involvement on-campus is an integral part of students' undergraduate tenure. The definition Astin provides highlights the importance of the students integrating themselves completely into the college experience and their campus environment. The involvement encompasses academics such as time studying, investment in degree completion, and interactions with their faculty, as well as participation in on-campus student involvement such as Greek Life, student leadership, and living in the residence halls. Case (2011) refers to the positive way students integrate into their campus life as being "purposefully involved" (p. 2). Astin (1985a) states five important components that drive the student involvement theory:

1. The investment of physical and psychological energy in various "objects." The objects may be highly generalized (the student experience) or highly specific (preparing for a chemistry examination); 
2. Regardless of its object, involvement occurs along a continuum. Different students manifest different degrees of involvement in a given object, and the same student manifests different degrees of involvement in different objects at different times;

3. Involvement has both quantitative and qualitative features;

4. The amount of student learning and personal development associated with any educational program is directly proportional to the quality and the quantity of student involvement in that program;

5. The effectiveness of any educational policy or practice is directly related to the capacity of that policy or practice to increase student involvement (pp. $135-136)$.

Astin's (1975) early work in student departure demonstrated key factors that promoted student success. He found that students who lived on-campus, were heavily engaged in their academics, participated in a large number of on-campus activities, and maintained full-time student status were more likely to be successful (persist to graduation) than their peers who did not. However, Astin's work focuses primarily on White students. While Astin's research indicates students should immerse themselves in diverse groups, for students of color, especially at Predominantly White Institutions (PWIs), groups and organizations which bring together students from certain backgrounds provides a safe sense of community and connectivity (Doan, 2011). St. John, Rowley, and Hu (2009) found that students of color, whose finances were covered for their post-secondary studies, were more likely to engage in involvement and leadership positions at a higher rate than any other racial group. A study by Alfano and 
Eduljee (2013) indicates $79 \%$ of residential students feel as if they are a part of their campus community versus only $43 \%$ of commuter students, with both groups indicating they would like to be more involved. Astin (1985a, 1985b) determined these factors are how students are "involved" on-campus and sought ways to encourage campuses to increase student involvement in order to decrease student attrition. The more connected students are to their campus, the greater their sense of community and desire for involvement on campus (Case, 2011). Astin saw student motivation as a factor that explains how involved students are with their campus.

Motivation is a substantive part of Astin's theory as the observable part of involvement (1985a, 1985b). Astin's Student Involvement theory encompasses the quantity and quality of students' involvement on campus. The quantity and quality of involvement are linked to students' motivation and how invested they are in each of their commitments (academics, student organizations, leadership, etc.). In addition to student motivation, student involvement theory also recognizes the finite amount of time a student has and how they allocate their time to be successful (Astin, 1985a). Therefore, colleges and universities need to focus on the amount of time students spend in various activities in order encourage persistence and benefits to the students.

In order for students to be successful and persist to graduation, Astin (1985a) believes administrators and faculty have to understand how to integrate all aspects of student involvement including their motivation to be involved and the amount of time they have to commit to their various commitments. Beyond what occurs on campus in classrooms, student organizations, and at student jobs, students also must manage their family lives and other factors external to their university life (Astin, 1985a). It is the 
amalgamation of all aspects of students' life, including place of residence, student involvement, and family obligations that have a significant impact on students' success in college. Another area in the work of student involvement is George Kuh's theory on student engagement that focuses student success through participation in high-impact experiences (HIPs). Kuh utilized Astin's work in student involvement as the catalyst for his own research. While Astin created a foundational level, Kuh furthered the concept relating to the value of involvement on-campus. Kuh's work led to the development of the National Survey on Student Engagement (NSSE), a survey used on many college campuses to assess their student engagement.

\section{High-Impact Experiences Programs}

There are ten High-Impact Experience Programs (HIP) identified from Kuh's research on student engagement (2008). The ten HIPs are first-year seminars and experiences, common intellectual experiences, learning communities, writing-intensive courses, collaborative assignments and projects, undergraduate research, diversity and global learning, service learning and community-based learning, internships, and capstone projects and courses (Kuh, 2008). HIPs are often collaborative and/or co-curricular in nature (Kuh, 2008). Kuh's HIPs are similar to Astin's student involvement given they focus on the opportunities available to students through academic and on-campus involvement. Ultimately, both student involvement and student engagement are meant to increase the likelihood students will persist to graduation. Students must make considerable personal investments to receive the full benefits of HIPs. According to Kuh (2008), students must actively engage in the activities that consume their time and efforts. The HIPs require students to interact with faculty and peers and, through those interactions, receive greater feedback about their participation 
(Kuh, 2008). Students who engage in HIPS are more likely to encounter greater diversity and find their experiences to be life altering (Kuh, 2008). Participation in HIPs allows for application of learning on- and off-campus (Kuh, 2008).

The determination of a policy's or practice's effectiveness, especially related to student involvement and HIPs, is increased student involvement (Astin, 1985b; Kuh, 2008). Therefore, colleges and universities need to consider the practices and policies on their campus that encourage student involvement and participation in HIPs. Research indicates students who participate in two or more HIPs are more likely to be engaged on campus and persist to graduation (Brownell \& Swaner, 2009; Kuh, 2008). The research also indicates greater benefits of HIPs (Kuh, 2008). Students with lower ACT scores earned higher GPAs their first year in college when participating in HIPs (Kuh, 2008). Hispanic and African-American students demonstrated greater academic gains from HIPS than their White counterparts (Kuh, 2008). Administrators looking to maximize their students' engagement need to consider practices and policies that encourage student involvement as well as participation in HIPS, especially for many underserved populations, such as students of color and first-generation students (Bower, \& Inkeles, 2010; Brownell \& Swaner, 2009; Kuh, 2008; Lopatto, 2010). One such area is participation in EA.

\section{Education Abroad}

The following sections provide historical background on the development of EA in higher education. After situating EA in a historical context, there will be an overview of who goes abroad, looking specifically at student demographics, which then leads to why students participate in EA. After looking at the participants and reasons for going 
abroad, there is a discussion of existing research related to EA and an initial review of the variables in the study.

\section{Brief History of Education Abroad}

Though there existed some earlier models related to EA, a more standard form of study abroad emerged after World War I. As the world was healing from the devastation of war, diplomacy became an important part of the recovery process. In the development of diplomacy there was a need for greater cultural understanding, thought to be achievable through study abroad programs. Stephen Duggan, Sr. along with two Nobel Peace Prize winners, Nicholas Murray Butler and Elihu Roberts, developed the Institute of International Education (IIE) (now known as the Power of International Education) in 1919 (IIE, 2015). The IIE founders believed peace was not sustainable in the absence of appreciating that which differentiated countries and cultures (IIE, 2015).

The early development of programs at colleges and universities began in the 1920s in the form of a Junior Year Abroad (JYA). The University of Delaware began an early version of a JYA in 1923 (Kochanek, 1998). A Modern Languages professor, also a veteran of WWI, presented the idea to the university president. To gain support, the professor and the president took their idea to then Secretary of Commerce, Herbert Hoover, who enthusiastically supported the program (Kochanek, 1998). The Delaware JYA program was somewhat unique in sending students abroad, as many of the early international education programs focused on sending professors abroad and bringing scholars to the United States. Delaware sent an initial six students over to France who flourished in the abroad program. Due to the success of the JYA program, it continued in subsequent years and expanded into Switzerland and Germany (Kochanek, 1998). The 
JYA program also began to accept students from other universities including Smith, Brown, Harvard, Wellesley, and Princeton (Kochanek, 1998).

The programs continued until WWII. Due to the aftermath of WWII, many changes came about in international education, including the University of Delaware ceasing their JYA program in 1948 (Kochanek, 1998). Despite the dissolution of this successful program, many positive developments in international education occurred in the 1940s. Possibly the most well-known initiative is the Fulbright Program (Fulbright, n.d.-b). The idea of Arkansas Senator J. William Fulbright, a bill was introduced to Congress in 1945 to promote "international good-will" (Fulbright, n.d.-a). Senator Fulbright suggested that the international education in areas such as education, culture, and science would be a positive use for surplus war funds (Fulbright, n.d.-a). The bill was signed law on August 1, 1946 by President Truman (Fulbright, n.d.-a). The goal of the Fulbright program was to increase diplomacy through the academic exchange of education, research, and thought. Another important development in the postwar 1940s was the development of two organizations that promoted international education. The first program is the National Association of Foreign Student Advisors (NAFSA) known since 1964 as the Association of International Educators (IIE, 2015; NAFSA, 2012). The second program, established in the 1940's, was the Council on International Education Exchange (CIEE) (IIE, 2015). Both NAFSA and CIEE work to extend international relations, primarily through education, international exchange, and advocacy.

From the 1950 s through the 1970 s, international education continued to grow with moderate success. Work in postwar and developing countries continued to be an important goal of IIE (IIE, 2015). The global perspective and interest in social welfare 
increased further by post-Vietnam programs like the Peace Corps. The Peace Corps, signed into law in 1963, was the brainchild of President Kennedy (Schur, 2000). The inception of the Peace Corps came about after Kennedy, arriving late at night to speak to University of Michigan students, suggested an international service program focusing on countries such as Africa, Asia, and Latin America (Schur, 2000).

The University of Delaware also revived their study abroad programs in the 1970s. While not initially a semester-long program, the university developed the Winterim, the time between fall and spring semester (Kochanek, 1998). During this time, students had the opportunity to study in many countries across Western Europe in such cities as London, Paris, Rome, Vienna, Geneva, and multiple locations in Germany (Kochanek, 1998). The program created so much interest that Pan American airlines chartered special flights for the Delaware students and painted "Delaware Clipper" on the fuselages (Kochanek, 1998). The popularity of the programs led to the development of various semester-long options. In more recent years, the idea of diplomacy has broadened to include business, nongovernment organizations, economics, politics, and commercialization (Ruel, 2013). With the business market expanding, the concept of people being global citizens became more commonplace. The concept of the global citizen continued through the 1990s and into the 21st century (Farrell, 2007). As our nation and economy become even more internationalized, Gray, Murdock, and Stebbins (2002) highlight the wide-reaching influence of events such as Tiananmen Square, the fall of the Berlin Wall, and the end of the Cold War. In more modern times, Stearns (2009) points to the government's increased focus on EA since 9/11 to help strengthen Americans' global understanding. De Wit (2009) also states, “The push for 
internationalization comes more from the State Department and the Defense Department, from private foundations and professional associations, and from institutions of higher education and their respective bodies, contributing to an active lobbying and advocacy tradition" (p. 213).

The history of EA provides context about the development international programs in higher education. The role of EA changed throughout time from one esteemed education to a form of diplomacy to a means of creating students prepared to function in an increasingly diverse society. The following two sections will review the students who choose to participate in EA and the reasoning behind the decision.

\section{Who Goes Abroad}

Kean and Hamilton (2008) write, "ignorance of the world is a national liability," (para. 6) and express concern about the lack of Americans who study abroad, given only $1 \%$ of enrolled students and $10 \%$ of college graduates spend some time abroad. The authors highlight America's level of "competition in an international environment when most of our citizens lack minimal exposure to, understanding of, the world beyond U.S. borders" (para. 5). The relatively small number of students who study abroad pales compared to the goal of having a million students study abroad by 2017 , as stated by the Senator Paul Simon Study Abroad Foundation Act (Kean \& Hamilton, 2008).

Given the overall U.S. college student population, less than $10 \%$ of students are going abroad (IIE, 2015). The profile of the typical education abroad student is White (74.3\%), female (65.3\%), attending a private college or university, studying the social sciences or humanities (42.4\%), and of middle or upper-class socioeconomic status (63.6\%) (IIE, 2015). However, IIE data indicate changes in overall participation. Recent 
Open Doors Reports (2018) show gains in the number of students going abroad who study business. Language acquisition, which used to be the primary reason for EA, now only accounts for $4 \%$ of the total number, and short-term EA (typically considered 8 weeks or less) is the primary duration abroad (IIE, 2015).

Another factor changing in EA is the location. According to the IIE Open Doors Report (2015), the top five destinations for EA are the United Kingdom (13\%), Italy (10\%), Spain (9\%), France (6\%), and China (5\%) with the UK, Spain, and Italy hosting nearly $32 \%$ of all EA participants. In the most current IIE Open Doors Report (2015), reporting data from academic year 2013-2014, over 44\% of EA occurs outside the top ten destinations. There is an increased interest in promoting EA to nontraditional locations such as Asia, Latin America, and Africa. One trend, which is slowly becoming more popular, is heritage EA (Twombly et al., 2012), based on Americans choosing EA in the location of their ancestral culture. The concept of heritage EA is not necessarily new when one considers the UK and Italy as the top two locations for EA and the number of Americans with ancestral roots to those countries. Heritage EA is increasingly more popular with minority students opting to participate in EA (Twombly et al., 2012). Concerted efforts, including heritage EA and faculty-led programs, exist to increase student participation in targeted populations, such as students of color, community college students, students studying business or science, technology, engineering, and math (STEM) disciplines, students who identify as LGBTQ, firstgeneration college students, and nontraditional locations (IIE, 2009; NAFSA, 2015). IIE Open Doors (2014), reports a 5.2\% increase in STEM student participation in EA in the 
past year. However, there is still room for increased participation with nontraditional populations.

Schock (2012) suggests students who participate in some sort of EA experience are better prepared to face the challenges of the twenty-first century and are prepared to engage globally in areas of foreign policy, national security, and economic security. Many colleges and universities see EA as a way to develop more culturally aware global citizens who are better prepared to handle the increasingly more globalized world. Merrill, Braskamp, and Braskamp (2012) state "Global perspective includes acquisition of knowledge, attitudes, and skills important to intercultural communication and holistic development of more complex epistemological processes, identities, and interpersonal relations" (p. 356 emphasis in original text). Merrill et al. (2012) also suggest that students with a higher global perspective will have a greater sense of self.

\section{Why Students Go Abroad}

With increased focus on internationalization on college campuses, "education abroad consistently appears as a primary means of developing global and intercultural competence among American students" (Twombly, Salisbury, Tumanut, \& Klute, 2012, p. 1). Various groups including government entities, colleges and universities, and businesses find the intercultural competence a necessary skill set for students (Salisbury, Umbach, Paulsen, \& Pascarella, 2009; Twombly et al., 2012). Salisbury et al. (2009) believe using a student choice model helps explain why students "participate in educationally valued experiences during college" (p. 122).

Student choice plays into the decision to participate in EA. Twombly et al. (2012) and Salisbury et al. (2009) state there are four primary areas factoring into the student's 
decision to go abroad: human capital, economic capital, social capital, and cultural capital. Human capital is the "knowledge or skills that could be advantageously increased by studying abroad" (Twombly et al., 2012, p. 39); economic capital is the "funds available to invest in study abroad" (Twombly et al., 2012, p. 39); social capital is considered the "information or networks that increase one's ability to gain access to study abroad" (Twombly et al., 2012, p. 39); and cultural capital is the "attitudes and values that contribute to increase social strata, prestige, and cultural refinement" (Twombly et al., 2012, p. 39). Throughout college, students make significant decisions that impact their progress towards earning a degree. Similar to questions raised around students' choices regarding their academic major, whether to work, and participation in student involvement/HIPS, are the choices and decision-making process related to participation in EA (Salisbury et al., 2009).

There are many stated benefits of EA. Cultural development (Anderson et al., 2006; Carlson \& Widaman, 1998), language acquisition (Brecht, Davidson, \& Ginsberg, 1995; Engle \& Engle, 2004; Freed, 1995; Huebner, 1995), and increased student persistence to graduation rates (Hamir, 2011; Sutton \& Rubin, 2010) are assets of EA to college students. EA participants report a greater understanding of and respect for world issues as well as a tendency to be less ethnocentric (Brux \& Fry, 2010).

The past two sections have provided insight into the students who select to go abroad. In addition, they discussed why students are more likely to participate in EA. The next section delves into the existing research on EA, building the foundation to justify the purpose of the existing study 


\section{Education Abroad Research}

Research in EA encompasses a variety of disciplines. For instance, EA research thoroughly documents that time abroad leads to positive foreign language acquisition (Brecht, Davidson, \& Ginsberg, 1995; Engle \& Engle, 2004; Freed, 1995; Huebner, 1995 ) and increased intercultural development (Anderson, Lawson, Rexiesen, \& Hubbard, 2006; Carlson \& Widaman, 1988), but an area developing in emerging research interest is EA and student persistence and degree completion (Hamir, 2011; IU News Room, 2009; Malmgren \& Galvin, 2008; Sutton \& Rubin, 2010; Young, 2008). It is important for EA research to move beyond the historical research foci (cultural and language development, etc.) and examine the relationship of an EA to the entire student experience. The research related to EA needs to evolve with students and post-secondary schools while providing a better understanding about the potential mutual benefits to both. The research in the present study contributes to the knowledge base and understanding of the influence of EA and student involvement on campus.

As colleges and universities seek to encourage greater participation in EA activities, it is important to chronicle the value of EA experiences. Students who participate in EA often describe an increased focus on their academics, greater world comprehension, and a greater commitment to the global community (Dwyer \& Peters, 2004). Studies on EA suggest students who spend time abroad demonstrate stronger foreign language ability, greater intercultural development, and personal growth. From an institutional perspective, students who go abroad are more likely to persist to graduation (Hamir, 2011; Sutton \& Rubin, 2010). 
Of interest to many colleges and universities and EA practitioners are the benefits of EA on student persistence. The existing research on EA participation and persistence varies due to the nature of the studies. Most studies are single institution, which creates questions of applicability to other post-secondary schools, especially when the colleges and universities are not similar in makeup (student population, location, public or private, etc.). Other studies may leave out populations of interest (there is extremely limited research on GLBTQ students and EA) or focus on EA duration (Dwyer, 2004). CSS data alone demonstrates students who have successfully persisted to graduation. However, coupled with the TFS, the data demonstrates long-term characteristics of the students who were successful at their college or university.

Malmgren and Galvin (2008) conducted a single institution study looking at EA benefits for high-achieving students, students in Science, Technology, Engineering, and Math (STEM) disciplines, and at-risk populations, including students of color. All participants spent at least three weeks abroad. The researchers tracked participants versus nonparticipants and their graduation rates in their study. The results of the statistical analysis indicate EA does not necessarily delay graduation. Results were statistically significant when comparing participants versus nonparticipants in EA. The correlations between students of color who participated in EA and graduation were strong. Students of color who went abroad demonstrated a greater likelihood to graduate, as did at-risk students (as defined in the study by their high school rank and test scores).

Sutton and Rubin (2010) were the lead researchers on the Georgia Learning Outcomes of Students Studying Abroad Research Initiative (GLOSSARI); which was a system-wide EA study for the University of Georgia System (UGS). One of the benefits 
of the GLOSSARI is that it is a ten-year longitudinal study (2000-2010) examining a variety of aspects related to education EA. The GLOSSARI study encompassed the entire UGS system, including rural and metropolitan four-year post-secondary schools as well as two-year schools. The UGS system database includes 31,000 individual EA records. Each record contains information such as the location of the EA, grade level of the participants when they participated in EA, academic major, and duration of their program (Sutton \& Rubin, 2010). The researchers cleaned the study records to include 19,109 EA participants and a control group of 17,903 nonparticipants (Redden, 2010). Through the database, the researchers were able to gather pertinent information including demographics, matriculation/graduation, preenrollment factors, UGS semester GPA, and transfers within the UGS. The longitudinal nature of the study provides nearly a decade's worth of data collection, and is therefore less affected by policies, trends, or other external factors that sometimes only momentarily impact a treatment group (Sutton \& Rubin, 2010). The control groups closely mirror the EA groups since not all students in the UGS will choose to participate in EA (Redden, 2010). Also, the makeup of the control groups was selected to reflect the post-secondary schools in the UGS system that are more apt to send students abroad (Redden, 2010). The study also considered other variables often of interest to researchers in higher education such as student demographics (male versus female, race, academic preparedness before college, college academic standing, academic major, etc.).

The results of the GLOSSARI study indicate that full-time, first-year students who study abroad have a six-year graduation rate of $88.7 \%$ compared to $83.4 \%$ graduation rate in the control group, which is significantly higher than the UG system 
that is graduating students at less than 50\% (Redden, 2010; Sutton \& Rubin 2010). Over a four-year period, EA participants graduated at rate of $49.6 \%$ compared to $42.1 \%$ the control group and 24\% for the entire UGS (Redden, 2010). Another important finding in the GLOSSARI study is that African-American students who participate in EA graduate at a $31 \%$ higher rate over four years than the students in the control group (Redden, 2010).

Hamir's (2011) work on EA and student persistence is a single-institution study from The University of Texas, an institution that consistently reports some of the greatest numbers of EA participation annually (IIE, 2015). The research is primarily quantitative with some qualitative interviews. Hamir's study did not use a random sample control group; her work divides the data by EA participants, EA applicants who did not follow through with their program, and nonparticipants, with the intention to control for motivation, often cited as a limitation in EA research. The results of Hamir's study showed EA participants were more likely to graduate in four years with diminished effects after the fourth year, which contrasts the findings of the GLOSSARI study.

The results from the GLOSSARI study, Hamir's (2011) research, and Galvin and Malmgren's (2008) study provide increased research on the benefits of EA on student persistence. As college and university leaders strive to make meaningful connections between the colleges and universities and students, EA is another way to create a highimpact experience for students. EA supports goals of student persistence as well.

Rust, Dhanatya, Furuto, and Kheiltash (2008) looked into the involvement of first-year students as a predictor of whether students participated in EA. While they highlight the low number of actual participation in EA, they found some predictors for 
EA participation through analysis of CIRP data. What Rust et al. discovered five factors that predict higher rates of desired EA participation. In creating five involvement scales including academic, social, political, diversity, and community, Rust et al. (2008), found the students who reported greater intent to participate in EA had higher scores in each of the five areas of involvement, with the greatest being in diversity. It is not surprising the students who expressed greater diversity involvement also express greater intent to participate in EA, as the students are more likely to be culturally aware and curious.

Kuh's (2008) work on HIPs demonstrates student-reported benefits of EA. Seniors who participated in EA and responded to the NSSE survey in 2006 reported significant gains at the $p<.001$ levels in deep learning, personal gains, and gains in general compared to their peers who did not go abroad (Kuh, 2008). In the same report, seniors who went abroad reported significance at $p<.001$ levels of academic challenge, active and collaborative learning, student-faculty interaction, and supportive campus environment (Kuh, 2008). Despite the positive gains students report, EA lags in comparison to other HIPS. According to Kuh, only $14 \%$ of seniors report going abroad compared to $19 \%$ conducting research with faculty, $46 \%$ participating in service learning, $53 \%$ participating in an internship, and 32\% completing a senior experience.

\section{Study Variables}

Many variables play into the EA experience; thus sex, race/ethnic identity, academic major, institutional characteristics, and student involvement will be included in the current study. Data from IIE indicates the typical EA participant is White, female, middle-to-upper class, STEM majors, and attending a private colleges and universities (IIE, 2015; Stroud, 2010). Knowing who tends to participate and the added benefits of spending time abroad, questions arise about how EA affects the students less likely to 
participate. It is also important to examine how the demographics of study abroad participation is changing. The percentage of students of color participating in EA (less than $25 \%$ ) is less than the percentage of students of color in the overall enrollment of undergraduate students (Salisbury et al., 2009; Stroud 2010). The introduction of shortterm EA may account for the changes in participation demographics. Original EA programs were Junior Year Abroad. Over time, the duration abroad shortened to a semester. Now there exist many programs that are two to eight weeks over summer and other college/university breaks (IIE, 2015; Stroud, 2010).

In the 1800 s men often spent time on a "world tour" returning to Europe to enhance their education (Benson, 2004; Hoffa, 2007). However, the "world tour" became more common with women, especially in elite circles, to ensure daughters were properly educated and worldly (Rouse, 2013). The trend continues as women participate in education abroad at higher levels than men (Salisbury et al., 2010). It was also more common for the academic majors women selected to benefit from study abroad (humanities, language) than men who were more likely to study business or STEM fields (Bui, 2014; IIE, 2009; McCullough, 2014), although the most recent IIE Open Doors report (2015) indicates most EA participants are in the STEM, business, and social sciences majors. Women are also more likely to think college is the only time they will be "free" to go abroad, unburdened by future family and career endeavors (Rouse, 2013). Men are less worried future responsibilities will inhibit their time abroad. More recently, the focus of EA practices examines how to increase participation in academic majors such as STEM fields (Lincoln Commission, 2005; Salisbury et al., 2009). With an 
increased focus in participation for specific academic majors (Stroud, 2010), which also tend to be male dominated, the sex demographic is also likely to change.

Sex

While initially a male-driven activity, the clear majority of EA participants are female students. From the IIE data, $65.3 \%$ of participants are female (IIE, 2015). The initial reasoning for more woman to participate in EA was due to their choices in majors (humanities and foreign language) and the historical perception that female students would later be too consumed with family responsibilities for extensive time abroad (Rouse, 2013). However, IIE data in 2015 indicates a larger number of STEM and business majors are participating in EA (IIE, 2015). The changes in major demographics and high participation in EA by female students may support the theory that female students do not believe they will have the freedom to travel at will in the future in contrast to their male peers. Goldin, Katz, \& Kuziemko (2006) discuss the changes in women's post-secondary graduation rates over the course of the $20^{\text {th }}$ century. In their data, there has been a rise in the number of women who complete their post-secondary education to the point where women now exceed men in graduation rates. With more women in post-secondary schools, who are historically more likely to go abroad, there is a larger pool from which to find EA participants.

\section{Race/Ethnic Identity}

According to IIE data, students of color are less likely to spend time abroad (IIE, 2015) despite the known and increased benefits of participating in EA. However, the findings of various studies and institutional reviews (Hamir, 2011; IU Newsroom, 2009; Malmgren \& Galvin, 2008; Sutton \& Rubin, 2010;) report positive effects from EA on 
student persistence for students of color and African-American students in particular. Since EA has the potential to be a positive factor in degree completion for students of color (as well as other identities), it is important to address the barriers students might encounter while trying to go abroad. The first issue a student might face is the lack of cultural capital on how to go abroad (who to talk to?, how to find classes that apply towards their degree?, how to find the financial resources to support their experiences?, etc.). It is important to also think about systemic barriers that might make it challenging for students of color to go abroad such as working while also enrolled in school, not having the mentors or support network to encourage such an endeavor, or the potential for microaggressions (comments on skin color, questions about sexuality, etc.) from individuals in their home or host school/country (Wills, 2015).

A new trend in education abroad relates to students' heritage, known as heritage study abroad (Landau, 2001). Students are opting to study in a location from which their ancestors or family came to the United States. Therefore, African-American students are selecting locations in Africa or the Caribbean, Hispanic students are choosing to study in Latin and Central America, and Asian students are selecting opportunities throughout Asia. Though the trend is relatively new and slowly gaining momentum, it may depict an eventual change in the ethnic and racial diversification of study abroad participants.

\section{Academic Major}

Similar to practices encouraging diverse gender and race/ethnicity participation, education abroad professionals work to encourage participation from a wider array of academic majors. In early forms of abroad programs, humanities and language majors easily coincided with the educational opportunities associated with overseas programs 
(IIE, 2015); while the rigidity of STEM programs made it difficult for students to find course opportunities. Often students state the lack of course equivalencies or the risk of a delayed graduation as a reason to not participate in EA. However, overseas educational opportunities are changing, and departments and faculty are finding more ways to allow classes from overseas to count toward degree requirements. EA professionals seek to introduce more EA opportunities for nontraditional majors such as STEM. With the increased focus on, as well as the evolution of globalized business, the areas of business and STEM are slowly starting to see changes in participation numbers with STEM having a 9\% increase in the most recent IIE Open Doors report (IIE, 2015). The introduction of faculty-led program is a newer form of EA that provides discipline specific programs. A faculty led-program is a short-term program where students travel and study with faculty typically from their home institution. Utilization of faculty-led programs allows for students in academic majors with strict requirements, sequential courses, or internship/ co-op commitments to spend time abroad and receive credit from their own department or college/university.

\section{Post-secondary School Characteristics}

Though originating at a public university (the University of Delaware), it is the private college and universities who have embraced EA programs. While overall numbers are higher at many public colleges and universities, the participation percentage is greater at private post-secondary schools (IIE, 2015; Salisbury et al., 2009), which is largely explained by the financing of education at a private college/university versus a public counterpart. It stands to reason students at private colleges and universities either have more money or access to more money (more private aid through their financial aid 
office), and therefore are more likely to participate. Given the previously stated positive outcomes related to studying overseas (Hamir, 2011; Sutton \& Rubin, 2010), there is a need to ensure students at public college and universities have access to affordable overseas programs.

\section{On-Campus Involvement}

As previously discussed, Astin's work is seminal in depicting the importance of student involvement to the collegiate experience and the successful degree completion $(1977,1984)$. The focus of the theory is encouraging students to stay connected to their college or university through psychological and emotional connections to their postsecondary school. The level of involvement is measured quantitatively and qualitatively. The study looks at student involvement during their high school years as well based on reported information in the TFS on academics, organizations, and intent to be involved at the collegiate level.

\section{High School Academics and Test Scores}

TFS collects data on the respondents' SAT, ACT, and AP scores as well as how many AP courses they pursued and their self-reported overall GPA. The high school academics is determined by self-reported data from students on the TFS, which are limited in scope. Atkinson and Geiser (2009) suggest that a student's "cumulative grade point average (GPA) in academic subjects in high school proved to be the best overall predictor of student performance in college," (p. 665). The SAT was first administered in 1926 and was an aptitude test to replace the College Boards, which were a written test (Atksinon \& Geiser, 2009). The ACT came about in 1959 and was meant to function as an achievement test (Atkinon \& Geiser, 2009). AP exams were introduced in 1955 by 
the College Board to provide more detailed knowledge of specific subjects (Atkinson \& Geiser, 2009). The data points collected for the purpose of the present study are SAT verbal scores, SAT math scores, SAT writing scores, ACT composite scores, GPA, and whether the student took AP classes.

\section{Cooperative Institutional Research Program (CIRP)}

Founded in 1966, the Cooperative Institutional Research Program (CIRP) is a comprehensive program and inventory that assesses the entire college student experience (HERI, 2015). CIRP is housed at the Higher Education Research Institute (HERI) at UCLA. Over the years, CIRP has amassed data on over 1,900 institutions, 15 million students, and 400,000 faculties (Astin, 2003; HERI 2015). CIRP, housed in the Higher Education Research Institute (HERI) at UCLA since 1973, was originally developed through the American Council on Education (ACE) with Alexander Astin as the lead developer and author (HERI, 2015).

According to Astin, the necessity for an inventory such as CIRP came about due to a need for longitudinal data allowing for a more effective way to compare two or more institutions (Astin, 2003). The outcome of an instrument such as CIRP underlines the value of faculty-student interactions, living on-campus, and the importance of student on-campus involvement (Astin, 2003). CIRP data are an accepted standard in the field of Student Affairs as evidenced by the fact that it is the most widely utilized data set in American higher education (Budd, 1990; Harrison, Comeaux, \& Plecha, 2006). There are several other CIRP programs including The Freshman Survey (TFS), Your First Year College Survey (YFYC), Diverse Learning Environments Survey (DLE), and the College Senior Survey (CSS) (HERI, 2015). The current study focuses on results obtained from the TFS and CSS. The CSS was first used in 1993. 


\section{Summary}

This chapter provided an overview of the existing literature on student involvement on campus, education abroad and existing research, and the variables used in the study. The background information on each of the topics helps situate the value of the study and the outcomes that were meant to benefit the field of education abroad. The next chapter reviews the methodology used in the study including the research design, hypothesis, research questions, and data analysis. 


\section{CHAPTER III}

\section{METHODOLOGY}

The following chapter outlines of the methodology of the study. The section briefly revisits the purpose of the study and the research design. After discussion of the research design, the chapter addresses the population and sample, variables, the data sources, and the College Senior Survey (CSS) and the Freshman Survey (TFS). Next the research questions, hypotheses, and data analyses were proposed.

\section{Purpose of the Study}

The purpose of the current study was to examine how intent to be involved in college student life (including student government, Greek life, NCAA/NAIA athletics, club sports, student clubs and organizations, and faculty research), intent to study abroad, and high school academic characteristics predict student participation in Education Abroad (EA) programs. Chapters one and two provide the background and purpose for the study. The study utilized Astin's (1984) Student Involvement Theory to define and clarify involvement for students on campus, including participation in campus organizations as well as academics, and research. The study focused on student intent to be involved based on responses to the TFS during their first semester. The study examined the characteristics of the student (sex, race/ethnicity, and academic major), the college characteristics (public versus private), academic characteristics, intent to go abroad, and intent to be involved. An adaption of Astin's conceptual Input- 
Environments-Outcomes model was used to analyze the data, thus only using InputsOutcomes (I-O). Figure 1 provides a depiction of the I-O model with the study variables.

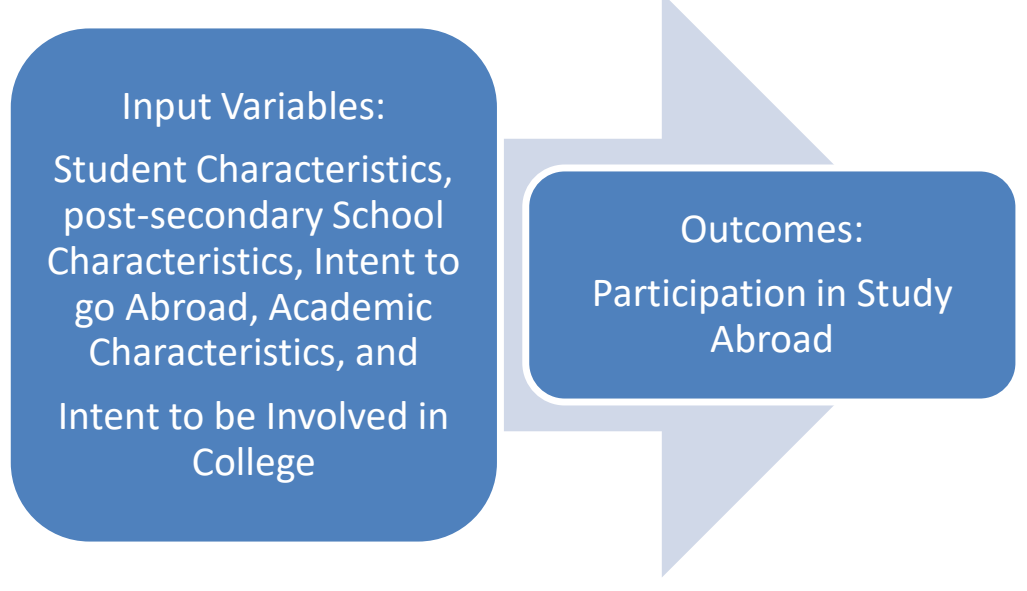

Figure 1. Astin's Input-Outcome model with study variables.

\section{Research Design}

The study was correlational examining the relationship between student characteristics, post-secondary school characteristics, intent to go abroad, academic characteristics, and intent to be involved in college as a means to predict participation in EA. The data were from a national survey where colleges and universities pay to participate. Due to the use of an existing data set and since the students are not assigned to a study abroad/nonstudy abroad group, the study is nonexperimental (Creswell, 2012). The study utilized data from the 2009 administration of The Freshman Survey and the corresponding 2013 College Senior Survey data. All participants in this study responded to both surveys. The electronic distribution of the survey was to a random sample of seniors from colleges and universities that paid to use the TFS in 2009 with their firstyear students and the CSS in 2013 with their students who were about to graduate. The 
survey information was a reflection on the self-reported students' experience and collected information after the students' experiences.

\section{Study Sample}

The sample for the study was the respondents to the 2009 the Freshman Survey (TFS) and the 2013 College Senior Survey (CSS) and resulted in 17,743 matched pairs that completed both surveys. Colleges and universities purchase the TFS and CSS that administers the survey to a random sample of first-year and senior year students typically distributed by email. Participation in the study was voluntary. HERI does not monitor the response rates at each post-secondary school that utilizes the CSS and therefore does not collect information about student response rates.

\section{Variables}

The study examined the relationship between intent to be involved in college, intent to study abroad, and high school academic characteristics as well as student characteristics and post-secondary school characteristics and participation in study abroad. The study examined the predictor variables student characteristics, postsecondary school characteristics, intent to go abroad, academic characteristics, and intent to be involved (including student government, Greek life, NCAA/NAIA athletics, club sports, student clubs and organizations, and faculty research) from the TFS. The dependent variable was a dichotomous variable of whether students participated in study abroad as self-reported on the CSS. Table 1 provides detailed information about the predictor and dependent variables in the study as well as how the variables are defined and coded. 


\section{Table 1}

Description of Study Variables per the TFS and CSS Surveys

\begin{tabular}{lll} 
Type of Variable & Variable & Level of Measurement \\
\hline $\begin{array}{l}\text { Dependent } \\
\text { Variable }\end{array}$ & $\begin{array}{l}\text { Education Abroad } \\
\text { Participation (EAP) }\end{array}$ & Nominal with two levels \\
\hline
\end{tabular}

Predictor

Variable

Student Characteristics

Sex Nominal with two levels

Race/Ethnic Identity Nominal with two levels

$\begin{aligned} & \text { Intended } \\ & \text { Major }\end{aligned}$
$\begin{aligned} & \text { Post-secondary } \\ & \text { School Characteristics }\end{aligned}$
$\begin{aligned} & \text { Intent to go abroad } \\ & \text { Academics } \\ & \text { Characteristics }\end{aligned}$
$\begin{aligned} & \text { Intent to be Involved } \\ & 7 \text { Nominal with two levels } \\ & 4\end{aligned}$
4 levels

After the data were reviewed and cleaned, it was determined that some of the predictor variables needed to be consolidated to better answer the research questions. Variables such as the SAT individual scores were first recoded to have a composite score 
by adding the SAT verbal and SAT math scores together. Since the ACT and SAT scores are reported on different scales, they were recoded into raw $z$-scores in order to have the data be meaningful for analysis (i.e., to put them on the same scale). An average $z$-score for both exams was utilized when students had scores for both exams. The student intent to be involved, AP courses taken, and GPA grade categories were recoded into binary variables in order to more easily examine the results in a regression analysis. The recoded study variables are displayed in Table 2.

\section{Table 2}

$\underline{\text { Recoded Study Variables }}$

$\begin{array}{lll}\text { Type of Variable Variable } \quad \text { Level of Measurement } & \begin{array}{l}\text { Definition of } \\ \text { Codes }\end{array}\end{array}$

\begin{tabular}{|c|c|c|}
\hline $\begin{array}{l}\text { Dependent } \\
\text { Variable }\end{array}$ & $\begin{array}{l}\text { Education Abroad } \\
\text { Participation (EAP) }\end{array}$ & Nominal with two levels \\
\hline
\end{tabular}

Predictor

Variable

$\begin{array}{lll}\text { Sex } & \text { Nominal with two levels } & \begin{array}{l}\text { Male }=0 \\ \text { Female }=1\end{array} \\ \text { Race/Ethnicity } & \text { Nominal with two levels } & \begin{array}{l}\text { White- }=0 \\ \text { Non-White=1 }\end{array}\end{array}$

Predictor

Student Characteristics
Nominal with five levels

Humanities

Art=0;

STEM/Health

Sciences $=1$;

Business=2;

Social

Sciences/

Education=3;

$4=$ Other 
Table 2

$\underline{\text { Recoded Study Variables (continued) }}$

\begin{tabular}{lll} 
Type of Variable $\quad$ Variable $\quad$ Level of Measurement & $\begin{array}{l}\text { Definition of } \\
\text { Codes }\end{array}$ \\
\hline
\end{tabular}

Post-secondary Nominal with two levels Private, 4-year

School Characteristics $\quad$ School $=0$;

Public, 4-year

School= 1

Intent to go abroad Nominal with two levels no=0; yes $=1$

Academics

Characteristics

Non

Two nominal variables with two levels One continuous variable

College entrance exams

AP course recode

GPA recode

$\mathrm{B}+$ or

$$
\begin{aligned}
& \text { Z-scores } \\
& \text { none }=0, \text { yes }=1 \\
& \text { B or less }=0, \\
& \text { higher }=1
\end{aligned}
$$

Intent to be involved Seven nominal variables with two levels

$$
\begin{aligned}
& \text { Intent to be involved with } \quad 0=\text { unlikely } \\
& \text { Student Government 1=likely } \\
& \text { Intent to join a fraternity } \quad 0=\text { unlikely } \\
& \text { Or sorority 1=likely } \\
& \text { Intent to participate in } \quad 0=\text { unlikely } \\
& \text { Intramural or club sports } 1=\text { likely } \\
& \text { Intent to participate in } \quad 0=\text { unlikely } \\
& \text { Intramural or club sports } 1=\text { likely } \\
& \text { Intent to participate in } \quad 0=\text { unlikely } \\
& \text { NCAA or NAIA athletics 1=likely }
\end{aligned}
$$


Table 2

$\underline{\text { Recoded Study Variables (continued) }}$

\begin{tabular}{lll} 
Type of Variable $\quad$ Variable & Level of Measurement & $\begin{array}{l}\text { Definition of } \\
\text { Codes }\end{array}$ \\
\hline & $\begin{array}{l}\text { Intent to join clubs and } \\
\text { organizations }\end{array}$ & $\begin{array}{l}0=\text { unlikely } \\
1=\text { likely }\end{array}$ \\
& $\begin{array}{l}\text { Intent to be study } \\
\text { abroad }\end{array}$ & $\begin{array}{l}0=\text { unlikely } \\
1=\text { likely }\end{array}$ \\
& $\begin{array}{l}\text { Intent to research with } \\
\text { faculty }\end{array}$ & $\begin{array}{l}0=\text { unlikely } \\
1=\text { likely }\end{array}$ \\
\hline
\end{tabular}

\section{The Freshman Survey}

The TFS is used to assess students' experiences pertaining to their personal and academic life (Keup, 2004). TFS can be used as a stand-alone assessment but can also be coupled with the FYCY and CSS; which provide longitudinal information on the college experience. Administration of the TFS started in 1966 and has been completed by over 400,000 students each year at college and universities nationwide (Astin, 2003; Keup, 2004). According to Sax, Lindholm, Astin, Korn, and Mahoney (2002) the TFS is a "normative profile of the American freshman population." Similar to the CSS, the large number of students who complete the TFS each year at many colleges and universities support the reliability and generalizability of the data results. 


\section{College Senior Survey}

The CSS is used to study the impact of experiences tied to academic, civic, and diverse outcomes (HERI, 2015). While researchers can use the instrument as a standalone survey, they can also pair the CSS with other CIRP surveys. According to HERI (2015) the CSS is meant to measure a "broad range of college outcomes and post-college goals and plans including: academic achievement and engagement, student-faculty interaction, cognitive and affective development, student goals and values, satisfaction with the college experience, degree aspirations and career plans, and post-college plans" (para. 2).

First administered in 1993, in 2012 20,747 seniors from 98 different colleges and universities responded to the CSS. There are fewer than 20 searchable articles and fewer than 15 dissertations utilizing CSS data. Some of the dissertations provide little to no information on reliability or validity of the CSS (BaileyShea, 2009; Horn, 2013; Krauth, 2011). Other dissertations rely heavily on the information provided for HERI. However, little information is provided on the validity and reliability of the CSS (Tallentire, 2015). Discussions concerning related to over- and underreporting are often cited as a limitation in surveys based on student self-reported data (Tallentire, 2015). Since the administration of the CSS is to a large number of students at colleges and universities each year, the large number of respondents helps in supporting the reliability of the generalizability of the data results. 


\section{The National Survey on Student Engagement}

The National Survey on Student Engagement (NSSE) is another instrument widely used by colleges and universities in order to track information about students' engagement and experiences while in college. The NSSE asks a question about study abroad, but the responses are more ambiguous with students selecting from done, plan to do, plan not to do, have not decided. Since the NSSE answers are not clearly yes or no, the CSS provides data that are clearer about student participation.

\section{Research Questions and Analyses}

The study presented six research questions with six hypotheses to examine the predictors to participate in EA. The data were analyzed with Statistical Package for Social Sciences (SPSS) (version 25) for Windows. The study was a retrospective, correlational design utilizing an existing data. It is retrospective due to the use of data gathered historically and correlational as it investigates the relationship between student involvement and study abroad.

To better understand student involvement and education abroad, the proposed study aimed to investigate the following research questions:

1. What is the relationship between the student background characteristics reported on The Freshman Survey and participation in study abroad?

Analysis: A chi-square analysis for each variable in SPSS was used to determine if there is a difference between the background characteristics.

2. Do students attending public and private post-secondary schools participate in study abroad at similar rates? 
Analysis: A chi-square analysis was run to determine if there is a difference between private and public post-secondary schools in their students who study abroad.

3. Is intention to study abroad as a first-year student related to actual participation in study abroad?

Analysis: A binary regression was utilized to determine the likelihood of actual participation in EA based on first-year intent to go abroad.

4. Does student academic performance (standardized college entrance exams, GPA, and AP courses) predict involvement in study abroad?

Analysis: A binary logistic regression was utilized to determine the likelihood of participation in EA based on high school academic outcomes as reported on the TFS.

5. Does intent to be involved in college student organizations, athletics, and/or faculty research predict EA participation?

Analysis: A binary regression was utilized to determine the likelihood of participation in EA based on intent to be involved in college and academic intent entering college.

6. Of the variables collected on The Freshman Survey, what are the best predictors of participation in study abroad?

Analysis: A binary regression was utilized to determine which factors in the model best predict participation in study abroad. 


\section{Data Analysis}

The study will utilize The Freshman Survey from (2009) College Senior Survey (CSS) from 2013. The descriptive data from CSS was run in order to observe the $\mathrm{N}$ for each variable. Table 3 presents the statistical analysis used in the study.

\section{Table 3}

$\underline{\text { Statistical Analyses Used in the Study }}$

\begin{tabular}{cll} 
Research Question & Analysis & $\begin{array}{l}\text { Predictor } \\
\text { Variables }\end{array}$ \\
\hline 1. & Chi-Square & Student Characteristics \\
2. & Chi-Square & $\begin{array}{c}\text { Post-secondary School } \\
\text { Characteristics }\end{array}$ \\
3 & Logistic Regression & Intent to go Abroad \\
4. & Logistic Regression & Academic Characteristics \\
5. & Logistic Regression & Intent to be Involved \\
6. & Logistic Regression & All Factors
\end{tabular}

\section{Data Cleaning}

The data were cleaned in order to account for students who did not respond to critical questions in the study in order to validate the results (Folsom, Osborne-Lampkin, \& Herrington, 2014). The data were recoded to represent all missing data as a number outside the binary response from those students who did respond. The analysis then recognized those numbers as outside the parameters of the test and excluded them in the analysis of the data while still reporting on the number of missing data points. 


\section{Chi-Square}

For questions 1 and 2, a chi-square analysis was used. A chi-square is a nonparametric test used when the dependent variable is considered nominal and tests "whether the observed frequencies differed significantly from the expected frequencies" (Shavelson, 1996, p. 552). Assumptions for a chi-square include: (a) data that are frequencies, levels that are mutually exclusive; (b) each data point must represent only one case and independent ("discrete categories" [Shavelson, 1996, p. 552]); and (c) there are two variables. All assumptions were met for utilization of a chi-square through observation of the data and confirmation of a dichotomous dependent variable. Limitations to using a chi-square analysis are the results do provide much information about the strength of the relationship and it is sensitive to sample size if it is too small.

\section{Binary Logistic Regression}

For questions 3, 4, 5 and 6, a binary logistic regression was used. Binary logistic regression was selected due to the dichotomous dependent variable of participation in EA. By using binary logistic regression, it was possible to predict where a data point falls in the dichotomous dependent variable as the independent variable changes. The assumptions for a binary logistic regression are: (a) the data points should be independent observations; (b) data should be binary, (c) the data should lack multicollinearity; (d) the data should not be influenced by outliers; and (e) there should be enough data to support the model (Osborne, 2015; Stoltzfus, 2012). Using the appropriate statistical tests, assumptions were checked before building the regression models. A Wald statistic is used to determine which explanatory variables in the model are significant. 
Model equation. In Equation 1 the general equation for the logit model was expressed, where $b_{0}$ represented the intercept and $b_{1}$ through $b_{10}$ denote the slope coefficients for the predictor variables and correspond with the constructs in the conceptual model ( $\mathrm{x}_{1}$ through $\left.\mathrm{x}_{10}\right)$.

Equation 1. General form of the Logistic Regression Model

$$
\operatorname{Logit}(\grave{Y})=b_{0}+b_{1} \mathrm{X}_{1}+b_{2} \mathrm{X}_{2}+b_{3} \mathrm{X}_{3} \ldots \ldots b_{10} \mathrm{X}_{10}
$$

The use of binary logistic regression was due to the dependent variable being categorical with two levels ( $0=$ did not study abroad; $1=$ participated in study abroad $)$ and the independent variable was interval or ordinal due to categorical dummy coding.

\section{Summary}

The information presented in this chapter provided the methodological framework of the proposed research study. The statistically analysis for each research question was discussed. The next chapter will provide the results from the data analysis. A full explanation of the results will be discussed. 


\section{CHAPTER IV \\ RESULTS OF THE STUDY}

The following chapter reviewed the results from the present study. The focus of the study was look at the predictor variables that influence participation in education abroad participation. The predictor variables used in the study can be grouped in the following categories: student characteristics, post-secondary school characteristics, intent to study abroad, academic characteristics, and intent to be involved in college activities.

\section{Descriptive Findings}

There were 14,743 paired matches from respondents to both the 2009 TFS and 2013 CSS. However, for some of the questions, the respondents opted to not answer. As stated in chapter three, the data were coded to identify missing data points. Table 4 provides information on student and post-secondary school characteristics. Sample sizes range from 14,191 to 14,743 .

Respondents were asked about their intentions to study abroad. Response categories were: No Chance, Very Little Chance, Some Chance, and Very Good Chance. The data were collapsed into a binary yes/no in order to deal with sparse cells where there were uneven distributions. On the CSS survey, the question pertaining to study abroad is a binary yes/no question regarding actual student participation in study abroad. The sample sizes ranged from 14,189 to 14,702 . Of the CSS sample $47.5 \%$ intend to participate in study abroad. 


\section{Table 4}

$\underline{\text { Percentage Table for Student and Post-secondary School Characteristics }}$

\begin{tabular}{|c|c|c|}
\hline & Characteristic & Percentage of Sample \\
\hline & Sex $=$ female & 62.1 \\
\hline 2 & Race $=$ White & 76.2 \\
\hline \multicolumn{3}{|c|}{ 3. Major } \\
\hline & Humanities, English, Arts & 12.3 \\
\hline & STEM & 34.7 \\
\hline & Business & 15.1 \\
\hline & Social Sciences and Education & 23.1 \\
\hline & Other & 14.3 \\
\hline & Private Post-secondary School & 90.3 \\
\hline
\end{tabular}

\section{Research Question 1}

How do background characteristics (sex, race/ethnicity, and academic major) differ in the students who actually study abroad versus those who do not?

The student background characteristics of sex, race/ethnicity, and academic major were analyzed through chi-square tests. EA participation rates for women $(45.9 \%)$ were about 1.5 times higher than for men $(31.4 \%), \chi^{2}(1)=297.6, p<.001$. EA participation rates for White students (42.2\%) were about 1.2 times higher than for non-White students, $(34.4 \%) \chi^{2}(1)=67.1, p<.001$. EA participations rate differed among majors $\chi^{2}$ $(4)=206.7, p<.001$. Across the majors, EA participation for Humanities $(48.5 \%)$ majors is 1.5 times higher than STEM (33.2\%), 1.15 times higher than Business (42.1\%), 1.35 times higher than Social Sciences and Education (36.2\%), and 1.2 times higher than Other majors (41.0). The percentage of participation within student characteristics is presented in Table 5. 


\section{Table 5}

EA Participation within Sex, Race/Ethnicity, Academic Major, and Post-secondary School Characteristics

$\begin{array}{ccc}\begin{array}{c}\text { Variable } \\ \text { Sex }\end{array} & \text { EA Participation Rate (\%) } \\ & \text { Female } & 45.9 \\ \text { Male } & 31.4 \\ \text { Race/Ethnicity } & 42.2 \\ \text { White } & 34.4 \\ \text { Non-White } & 48.5 \\ \text { Major } & 33.2 \\ & \text { Humanities, Arts, and Language } & 42.1 \\ & \text { STEM } & 36.2 \\ & \text { Business } & 41.0 \\ & \text { Social Science and Education } & \\ & \text { Other } & \\ \end{array}$

\section{Research Question 2}

How do private versus public post-secondary schools differ in their student participation in study abroad?

The post-secondary school characteristics were analyzed through a chi-square test. EA participation rates for students at private colleges and universities (42.8\%) were about 2.5 greater than for public colleges and universities $(17.5 \%), \chi^{2}(1)=341.1, p<$ .001. The percentage of participation within post-secondary school characteristics is in Table 6. 


\section{Table 6}

EA Participation within Post-secondary School Characteristics

Variable

Post-secondary School Characteristics

Private

Public
EA Participation Rate

42.8

17.5

\section{Research Question 3}

Does intent to study abroad predict participation in study abroad?

Table 7 presents the descriptive data of students who intended to study abroad.

The initial Yes/No were reported on the TFS. The data were then run in a crosstab to determine which students actually participated in study abroad as reported on the CSS who intended to as reported on the TFS.

\section{Table 7}

EA Participation for Intent to Study Abroad Based on TFS Survey and Actually Participated

Variable

Intent Study Abroad

Yes (Participated in EA)

No (But did Participate in EA)
EA Participation Rate

60.2

23.7

EA participation rates for students who intended to go abroad (60.2\%) were about 2.5 times greater for students who as first year students did not intend to go abroad, but 
actually did participate in study abroad $(23.7 \%), \chi^{2}(1)=1908.79, p<.001$. Table 8 presents the statistical findings of the regression analysis.

\section{Table 8}

Logistic Regression Results: Intent to Study Abroad as a Predictor of Actual Participation

\begin{tabular}{|c|c|c|c|c|c|c|c|}
\hline Variables & $B$ & S.E. & Wald & $d f$ & Sig & $\operatorname{Exp}(B)$ & $\begin{array}{l}\text { 95\% C.I } \\
\text { EXP(B) } \\
\text { Lower Upper }\end{array}$ \\
\hline Intent & 1.58 & .04 & 1908.79 & 1 & $<.001$ & 4.88 & 5.24 \\
\hline
\end{tabular}

Note-The constant is $\mathrm{B}=-.39$ for intent to study abroad.

\section{Research Question 4}

Does a students' personal high school academic characteristics (standardized college entrance exam scores, GPA, and AP courses) predict involvement in study abroad?

A regression analysis was used to examine the relationship between a student's high school academic characteristics and their participation in student abroad. The odds ratio for college entrance exams indicates that for each unit a student's z-score increases, there is a 1.4 increase in the odds of participating in study abroad (i.e., students who have a $z$-score of 1 on their college entrance exams have 1.4 times greater odds of participating in study abroad than students whose $z$-scores are at the mean). For students taking AP courses, the odds ratio indicates that the odds of studying abroad for students who took AP courses were 1.31 times larger than the study abroad odds for the students who did not take AP exams. With student GPA, the odds ratio indicates that the odds of studying 
abroad for students who reported making a B+ or higher in high school were 1.28 times larger than those students who intend to make a B or lower. Table 9 presents the statistical findings.

\section{Table 9}

Logistic Regression Results High School Academic Characteristics as a Predictor of Actual Participation

\begin{tabular}{|c|c|c|c|c|c|c|c|c|}
\hline Variables & $B$ & S.E. & Wald & $d f$ & Sig & $\operatorname{Exp}(B)$ & \multicolumn{2}{|c|}{$\begin{array}{l}95 \% \text { C.I } \\
\text { EXP(B) } \\
\text { Lower Upper }\end{array}$} \\
\hline 1. ACT/SAT & .30 & .02 & 174.80 & 1 & $<.001$ & 1.35 & 1.29 & 1.41 \\
\hline 2. AP & .27 & .06 & 20.87 & 1 & $<.001$ & 1.31 & 1.17 & 1.47 \\
\hline 3. GPA & .25 & .08 & 11.09 & 1 & $<.001$ & 1.28 & 1.11 & 1.48 \\
\hline
\end{tabular}

Note-The constant is $\mathrm{B}=-.26$ for high school academic characteristics.

\section{Question 5}

Does intent to be involved in college campus activities (participate in student government, join a fraternity or sorority, participating in club/IM sports, participate in NCAA/NAIA athletics, join clubs and organization, and working on faculty research) predict EA participation?

A regression analysis was used to determine if intent to be involved in college activities (student government, Greek life, club and intramural sports (IM), NCAA/NAIA sports, clubs and organizations, and faculty research) predicts participation in study abroad. EA participation rates for students who intended to be involved with student 
government (46.4\%) were about 1.3 times greater for students who as first year students did not intend to participate in student government, but actually did participate in study abroad $(36.8 \%), \chi^{2}(1)=51.96, p<.001$. EA participation rates for students who intended to participate in fraternities and sororities (41.0\%) were about 1.03 times less for students who as first year students did not intend to participate in fraternities and sororities, but actually did participate in study abroad $(39.7 \%), \chi^{2}(1)=2.79, p<.001$. EA participation rates for students who intended to participate in IM/club sports (45.6\%) were about 1.2 times greater for students who as first year students did not intend to participate in IM/club sports, but actually did participate in study abroad (37.3\%), $\chi^{2}(1)=53.99, p<$ .001. EA participation rates for students who intended to participate in NCAA/NAIA sports (41.7\%) were about 1.08 times less for students who as first year students did not intend to participate in NCAA/NAIA sports, but actually did participate in study abroad $(38.5 \%), \chi^{2}(1)=23.44, p<.001$. EA participation rates for students who intended to participate in clubs/organizations (46.7\%) were about 1.5 times greater for students who as first year students did not intend to join clubs/organizations but actually did participate in study abroad $(31.1 \%), \chi^{2}(1)=54.00, p<.001$. EA participation rates for students who intended to participate in faculty research $(40.8 \%)$ were about 1.04 times less for students who as first year students did not intend to do faculty research, but actually did participate in study abroad $(39.2 \%), \chi^{2}(1)=33.71, p<.001$. Table 10 presents statistical findings. 


\section{Table 10}

Logistic Regression Results: Intent to be Involved in Campus Student Activities as a Predictor of Actual Participation in Study Abroad

\begin{tabular}{lccccccccc}
\hline & & & & & & & \multicolumn{2}{l}{$\begin{array}{l}\text { 95\% C.I } \\
\text { EXP(B) }\end{array}$} \\
Variables & $B$ & S.E. & Wald & $d f$ & Sig. & $\operatorname{Exp}(B)$ & \multicolumn{3}{l}{ Lower Upper } \\
\hline 1. Stud Gov & .27 & .04 & 51.96 & 1 & $<.001$ & 1.30 & 1.21 & 1.40 \\
2. Frat/Soror & -.06 & .04 & 2.79 & 1 & $<.095$ & .94 & .88 & 1.01 \\
3. IM/Club & .28 & .04 & 53.99 & 1 & $<.001$ & 1.32 & 1.22 & 1.42 \\
4. NCAA/NAIA & -.18 & .04 & 23.44 & 1 & $<.001$ & .84 & .78 & .90 \\
5. Clubs/Orgs & .28 & .04 & 54.00 & 1 & $<.001$ & 1.78 & 1.66 & 1.92 \\
6. Research & -.23 & .04 & 33.71 & 1 & $<.001$ & .80 & .74 & .86 \\
\hline
\end{tabular}

Note-The intercept is $\mathrm{B}=-.39$ for intent to be involved in campus student activities.

\section{Research Question 6}

Which variables best predict participation in study abroad?

A logistic regression analysis with a stepwise backward elimination was used to determine which variables best predict participation in study abroad. The procedure removed NCAA/NAIA participation, Participate in Clubs and Organizations, and Join a Fraternity/Sorority as they did not improve the model. EA participation rates for students who intended to go abroad (60.2\%) were about 2.5 times greater for students who as first year students did not intend to go abroad, but actually did participate in study abroad (23.7\%), $\chi^{2}(1)=903.40, p<.001$. EA participation rates for students who attended private post-secondary $(42.8 \%)$ were about 2.4 times greater for students who as first 
year students who attended public post-secondary schools, but actually did participate in study abroad $(17.5 \%), \chi^{2}(1)=88.30, p<.001$. EA participation rates for female $(70.5 \%)$ were about 2.4 times greater than male students, but actually did participate in study $\operatorname{abroad}(23.7 \%), \chi^{2}(1)=117.51, p<.001$. EA participation rates for students who are White $(76.2 \%)$ were about 3.2 times greater for students who as first year students who were not white, but actually did participate in study abroad $(23.8 \%), \chi^{2}(1)=45.74, p<$ .001. EA participation rates for students who took AP courses (44.1\%) were about 1.4 times greater for students who as first year students did not intend to take AP courses, but actually did participate in study abroad $(30.8 \%), \chi^{2}(1)=10.29, p<.001$. EA participation rates for students who did not intended to participate in faculty research (40.8\%) were about 1.04 times less for students who as first year students intend to do faculty research, but actually did participate in study abroad $(39.2 \%), \chi^{2}(1)=15.72, p<.001$. EA participation rates for students who intended to participate in IM/club sports $(45.6 \%)$ were about 1.2 times greater for students who as first year students did not intend to participate in IM/club sports, but actually did participate in study abroad $(37.3 \%), \chi^{2}(1)=$ $17.11, p<.001$. EA participation rates for students who reported a $\mathrm{B}+$ or higher on their high school GPA (42.4\%) were about 1.5 times greater for students who as first year students who reported a high school GPA of a B or lower, but actually did participate in study abroad $(27.4 \%), \chi^{2}(1)=4.41, p<.001$. EA participation rates for students who intended to be involved with student government (46.4\%) were about 1.3 times greater for students who as first year students did not intend to participate in student government, but actually did participate in study abroad (36.8\%), $\chi^{2}(1)=3.72, p<.001$. 
The remaining variables in the model explain $24 \%$ of the variance in the study

abroad decisions based on the Nagelkerke $R^{2}, R^{2}=.24, \chi^{2}(1)=.87, p<.001$. The outcome indicates that the model is $70 \%$ correct in predicting study abroad participation.

Table 11 provides more information about the model.

\section{Table 11}

Logistic Regression Results: Variables which are Best Predictors for Study Abroad

\begin{tabular}{|c|c|c|c|c|c|c|c|c|}
\hline Variables & $B$ & S.E. & Wald & $d f$ & Sig. & $\operatorname{Exp}(B)$ & $\begin{array}{l}95 \% \\
\text { EXP } \\
\text { Lowe }\end{array}$ & $\begin{array}{l}\text { U) } \\
\text { Upper }\end{array}$ \\
\hline 1. Intent & 1.4 & .05 & 903.40 & 1 & $<.001$ & 4.04 & 3.68 & 4.42 \\
\hline 2. School & .87 & .93 & 88.30 & 1 & $<.001$ & 2.40 & 2.00 & 2.87 \\
\hline 3. Sex & .53 & .05 & 117.51 & 1 & $<.001$ & 1.70 & 1.54 & 1.87 \\
\hline 4. $\mathrm{R} \& \mathrm{E}$ & -.38 & .06 & 45.74 & 1 & $<.001$ & .70 & .61 & .77 \\
\hline 5. ACT/SAT & .28 & .03 & 112.36 & 1 & $<.001$ & 1.32 & 1.25 & 1.40 \\
\hline 6. AP & .21 & .07 & 10.29 & 1 & $<.001$ & 1.23 & 1.09 & 1.40 \\
\hline 7. Research & -.20 & .05 & 15.72 & 1 & $<.001$ & .82 & .74 & .90 \\
\hline 8. IM/Club & .19 & .05 & 17.11 & 1 & $<.001$ & 1.21 & 1.11 & 1.33 \\
\hline 9. GPA & .18 & .08 & 4.41 & 1 & $<.036$ & 1.19 & 1.01 & 1.41 \\
\hline 10. Stud Gov & .09 & .05 & 3.72 & 1 & $<.054$ & 1.09 & 1.00 & 1.20 \\
\hline \multicolumn{3}{|c|}{ 11. Major (TFS) } & 43.89 & 4 & $<.001$ & & & \\
\hline Business & -.49 & .07 & 44.80 & 1 & $<.001$ & .62 & .53 & .71 \\
\hline Other & .11 & .08 & 1.93 & 1 & $<.164$ & 1.11 & .96 & 1.29 \\
\hline
\end{tabular}




\section{Table 11}

Logistic Regression Results: Variables which are Best Predictors for Study Abroad (continued)

\begin{tabular}{|c|c|c|c|c|c|c|c|c|}
\hline Variables & $B$ & S.E. & Wald & $d f$ & Sig. & $\operatorname{Exp}(B)$ & \multicolumn{2}{|c|}{$\begin{array}{l}95 \% \text { C.I } \\
\text { EXP(B) } \\
\text { Lower Upper }\end{array}$} \\
\hline STEM & -.04 & .09 & .23 & 1 & $<.631$ & .96 & .80 & 1.14 \\
\hline $\mathrm{SS} / \mathrm{E}$ & .02 & .80 & .08 & 1 & $<.772$ & 1.02 & .87 & 1.21 \\
\hline
\end{tabular}

Note. Predictors are abbreviated as follows: Intent is study abroad intent, school is postsecondary school characteristics (public or private), ACT/SAT is college entrance exams, IM/Club is participating in Club/IM sports, GPA is self-reported GPA, Stud Gov is joining student government, Research is work on faculty research, $R \& E$ are race/ethnicity, Major is as reported on the TFS, SS/E is Social Sciences and Education, Frat/Soror is joining a fraternity or sorority, NCAA/NAIA is participating in NCAA/NAIA sports, Clubs/Orgs is joining clubs and organizations, and Research is work on faculty research.

Note-the intercept is $\mathrm{B}=-.25$ for the best predictors.

\section{Summary}

The chapter started with a review of the frequency data and then proceeded into the results of the data analysis. From the frequency data, the majority of students who study abroad are female, White, and intend to major in a STEM field. However, participation rates in EA are highest among students intending to major humanities, arts, and language and lowest among students intending to major in STEM and Business. It was determined that a student's sex, race/ethnicity, and intended major are factors in participation in study abroad as well as the characteristics of college or university a student attends. Intent to study abroad is significant and by far the best criterion variable in predicting study abroad participation. A student's academic characteristics as they 
related to college entrance exams, AP courses, and GPA are also significant in predicting a student's participation in study abroad. In looking at intent to be involved, intent to join a fraternity or sorority does not predict study abroad participation. However, intent to join student government, intent to participate in IM/Club sports, and intent to join clubs/organizations positively predict study abroad participation while intent to participate in NCAA/NAIA sports and faculty research were negative predictors of study abroad participation.

Stepwise regression with backwards elimination was used to identify the most parsimonious model for predicting SA decisions. This model indicates that college entrance exams, AP courses, student sex, intent to participate in Club/IM sports, intent to join student government, intent to study abroad, intended major, and post-secondary school characteristics are the best positive predictors for study abroad participation. Student intent to participate in faculty research was negatively associated with SA decisions, as was student race/ethnicity (students identifying as members of a racial/ethnic minority group were less likely to study abroad). Reported high school GPA, intent to join a fraternity or sorority, NCAA/NAIA athletics, and intent to join clubs and organizations were not significant in the model with all variables included. 


\section{CHAPTER V}

\section{DISCUSSION, FUTURE DIRECTIONS, AND CONCLUSION}

The dissertation has presented questions related to predictor variables and study abroad participation. Study abroad participation was determined by student self-reported responses to The Freshman Survey (TFS), which they responded to at the beginning of their first-year in college. The survey results were matched with the same students' responses to The College Senior Survey (CSS) administered by their college or university towards the end of the senior year of college. Both surveys are voluntarily. The research questions in the study examined study abroad and the variables related to student characteristics (sex, race/ethnicity, intended major), post-secondary school characteristics (public or private), intent to study abroad, academic characteristics (college entrance exams, AP courses, and GPA), and intent to be involved in college (Join Student Government, Join a Fraternity or Sorority, Participate in IM/Club sports, Participate in NCAA/NAIA athletics, Join Clubs/Organizations, and Work on Faculty Research). The following sections discuss the results of the research findings.

\section{Discussion}

The summary of findings discusses the results of the research questions in the study. Included in the Summary of Findings will be information about the results of the research questions as well as other pertinent details including demographics. 


\section{Demographics}

The paired TFS and CSS from HERI provided information on the student's sex, race/ethnicity and intended major. Historically, the typical study abroad student was White, female, studying humanities, and attended a private post-secondary school (IIE, 2015; Stroud, 2010). Of the respondents to both surveys, the majority were female (62\%), White (76.2\%), intended to be STEM majors (34.7\%), attended a private postsecondary school (90.7\%) and less than half participated in study abroad (40.3\%). From the percentage students that studied abroad, the majority were female $(70.5 \%)$, White (79.7\%), were intended STEM majors (28.4\%), and attended private post-secondary schools $(42.8 \%)$.

The demographics of study abroad participants based on the TFS and CSS surveys are comparable to national data in relation to sex, race/ethnicity, and postsecondary school characteristics. The study confirmed that the national data trends hold true in the study with the major of participants being White females who attend private colleges or universities as also demonstrated in the results of research questions one and two (IIE, 2018; Stroud, 2010). The study results indicate that while there is some increase in participation in study abroad participation by students of color since in 20002001, still $84.3 \%$ of participants were White (IIE, 2014), which supports previous studies about why students of color do not participate in study abroad due to finances and cultural capital (Salisbury et al., 2008). The analysis of the data from the study provide an updated perspective on which majors are studying abroad. While the historical literature indicates that Humanities majors were the most likely to study abroad, more recent data (IIE, 2018) indicate Business and STEM majors are studying abroad in higher 
percentages, perhaps due to a concerted effort by college and university leaders to make programs available to their students. The study results indicate a greater number of intended STEM majors were the most likely to study abroad, as reflected in the 2014 Open Doors Fast Fact Data (IIE, 2014) which would report on students graduating in 2013. However, from within the majors, more Humanities, Arts, and Language majors are studying abroad. The increase of participation from majors outside the Humanities is a focused effort in order to provide more options and opportunities for study abroad. It is also indicative of the development and popular short-term study abroad programs, which are more prevalent than historical study abroad programs that lasted a semester or the full academic year. With short-term programs, students majoring in STEM fields are less likely to disrupt the sequential nature of their academic programs. Faculty-led programs are also beneficial in making study abroad an option for students in STEM majors as they can take courses with faculty from their respective disciplines and campuses.

There is interest about why Business and STEM majors have not studied abroad at the same rate as Humanities majors in the past. With Business majors, it is believed a cost analysis of the actual benefits of going abroad as they relate to cost influence the decision to go abroad (Twombly et al., 2012). And while cost is one aspect that Business majors are more likely to consider, there is also the concern about time to degree. It is believed many Business majors decide to not study abroad as they believe it will delay their degree completion (Twombly et al., 2012). For STEM majors, the concerns have to do more with the hierarchical nature of their classes. Since each semester the course works builds on the previous one, students are concerned to take a break from their courses to study abroad as well as not taking the right courses to prepare them for the 
academic level of the STEM classes at their home college or university when they return (Twombly et al., 2012). In order to promote more STEM majors going abroad, more colleges and universities are establishing their own programs which are STEM focused and allow the students to stay on track with their degree requirements (Twombly et al, 2012). Overall, there is a great need for all majors to study abroad in order to be competitive in a global workforce.

\section{Predictors for Study Abroad}

The third research question in the study examined intent to study abroad. The ACE (2008) data indicated $50 \%$ of high school students intend to study abroad. Per the current IIE (2018) study data, the percentage of students who intend to study abroad is about three percentage points (47.5\%), just slightly less than the ACE (2008) data. However, the actual participation rate is lower with only $40.3 \%$ of respondents to the TFS and CSS actually participating. The numbers presented by the students in the TFS and CSS data are also much higher than reported by IIE (2014) data, which reported that $1.5 \%$ of undergraduates were abroad in $2012-2013,9.4 \%$ of students earning undergraduate degrees went abroad (Associate's and Bachelor's), and only $14.3 \%$ of Bachelor degree-seeking students studied abroad while pursuing their degree.

The HERI data were influenced heavily by the large percentage of private postsecondary schools that participate in the surveys. Of the respondents for the study, 90.3\% were from private colleges and universities. Financial access is a concern for students when considering study abroad participation (Salisbury, Paulsen, \& Pascarella, 2011; Twombly et al., 2012). For students who are attending a private post-secondary school, the increased costs of study abroad might not be as noticeable given the cost to 
attend a private college or university. Students who attend a public college or university might find studying abroad more expensive due to increased program costs as well as ancillary expenses. Students from lower income family might also lack the cultural capital necessary to seek out external funding, such as scholarships, in order to meet the costs associated with going abroad. A first-generation and/or low income student might not know who to talk to about spending time abroad, let alone be comfortable with associated travel.

Student academic characteristics were examined in the study. More precisely, the students' participation in AP courses, their self-reported GPAs, and a raw score of the average of their college entrance exams (ACT and SAT). The results of the study indicate students who took AP courses, reported a B+ or higher in their GPA, or increased their ACT/SAT were more likely to study abroad. Previously stated in Astin's $(1984,1999)$ model, motivation is the psychological force behind student involvement. Motivation is the manifestation of the psychological act and is applicable to students' achievement in academics. Based on examining the academic characteristics, students who are more academically motivated are more likely to participate in study abroad. Astin's Theory of Student Involvement (1984) assesses student involvement in college as a predictor they will persist to graduation. Rust et al. (2008) conducted an OLS study using CIRP data from 2003 where their study results indicated that involvement in diversity, social, community, academic, and political activities indicated students are more likely to go abroad. For the purpose of the current study, the involvement questions utilized from the TFS and CSS data were the student's intention to join student government, join a fraternity or sorority, participate in IM/club sports, 
participate in NCAA/NAIA athletics, participate in clubs/organizations, and work on faculty research. The results of the study suggest certain types of involvement are better than other involvement for accounting for the decision to participate in study abroad. Student government, IM/club sports, and participation in clubs/organizations positively predicted study abroad participation when included only in the intent to be involved model. NCAA/NAIA athletics and working on faculty research were negatively associated with predicting study abroad participation which is not surprising given the time commitment required of athletics and research. Joining a fraternity or sorority was not significant in the model for predicting study abroad. The results of the current study do not completely support the Rust et al. (2008) results. In the current study, individual questions from the TFS and CSS were used as predictors for study abroad whereas the Rust et al. article took questions from the two surveys and created scales. Using academic, social, political, diversity, and community scales as predictors of study abroad involvement, the Rust et al. (2008) articles indicates that student involvement accounts for 15.7 percent of the variation that students would participate in study abroad. However, the Rust et al. study included more information about diversity, community, and politics from questions on the two surveys and did not necessarily include athletics involvement (IM/Club or NCAA/NAIA). While Malgren and Galvin (2008) indicated students of color who study abroad were more likely to persist to graduation, the current study indicates that students of color are less likely than White students to go abroad. If study abroad is a path of persistence for student of color, then greater effort needs to be made to encourage students of color to participate in education abroad experiences. The GLOSSARI study indicates that students who study abroad are $10.0 \%$ more likely to 
graduate in four years from college than students who do not participate (Sutton \& Rubin, 2010); which also shows increased graduate rates for males and students of color. And while the current study did not focus on graduation rates, it did demonstrate that men and students of color study abroad at a lesser rate than White and female students. Therefore, increasing study abroad participation rates of male students and students of color is beneficial for the students and the post-secondary schools. The current study provides insight into what factors are influential in knowing which students have a great likelihood to go abroad, thus creating an opportunity for post-secondary schools to develop interventions, such as scholarships, cultural mentoring/ambassador programs, developing heritage study abroad, opportunities for students to go abroad earlier in the academic career, and tailoring programs to specific college subcultures, to get more students to participate in education abroad.

The model with all the predictor variables is different when all the variables are included together. This is most notable that when all variables are in the model to account for study abroad participation. All the variables in the model explains $16 \%$ of the variance for student participation in EA programs.

\section{Implications for Practice}

The results of the study provide insight for professionals working in study abroad. Practitioners can utilize the results to develop appropriate programs for differing student groups on their campus. The results also help provide insight about which students are more likely to go abroad. By knowing who is more likely to go abroad, study abroad practitioners can develop study abroad programs with the intent to avoid attrition in the

process. Practitioners also have the opportunity to utilize interventions for students less likely to go abroad. 
In recent years, the majority of students who study abroad participate in shortterm study abroad programs. Short-term study abroad programs are designated as programs that last in 2-8 weeks in duration (Kehl \& Morris, 2007-2008; IIE, 2014). The popularity of short-term programs is connected to students' desires to not be separated from their campus experiences for longer amounts of time, get out of sequence with their major, interrupt their pathways to student leadership and/or lose opportunities with employment and internships.

The opportunity for short-term study abroad also allows students to stay involved with campus activities. For a subset of students, their continued involvement with campus activities is important as they intend to eventually pursue leadership positions with organizations in which they are involved. This may be particularly true for students involved in Greek Life, Student Government, and students involved with clubs and organizations. While short-term study abroad at the minimum provides the opportunity to go abroad, some education abroad professionals indicate that such a short time abroad does not allow for the rich cultural immersion that comes from spending a semester or longer abroad (Dwyer, 2004; Kehl \& Morris, 2007-2008). Given the duration of shortterm study abroad, it might help students who are working on faculty research, although it would be dependent on the nature, timing, and duration of the research. And while not often discussed, there is potential for undergraduate research programs that involve participating in the research activities while abroad.

Over the years, there exists a substantial increase in the number of STEM student participation in study abroad. It is likely that the introduction of short-term study abroad programs has increased participation in study abroad. The short-term nature of the 
programs allows STEM students to avoid the potential consequences of a traditional study abroad program, which might include an interruption in the sequential nature of their course work.

Knowing which students are more likely to go abroad is important for practitioners in study abroad. Using the data, study abroad opportunities can be customized to encourage student interest in participating in an overseas program. Whether the programs are a semester or longer or a short-term program, understanding who is more likely to go abroad creates an opportunity to tailor the experience towards students' needs. As many study-abroad offices are limited in resources, knowing who to market programs to allows study abroad professionals to be more intentional with their programmatic efforts.

Study abroad offices are able to examine data results and determine how to best create and market programs that serve majors less likely to go abroad. Perhaps similar to the initiatives that have been successful for increasing STEM participation in study abroad can be adapted to help promote international opportunities for other majors such as education which is heavily burdened by curriculum standards and policies. In general, for study abroad programs to be successful, buy-in from the academic units as well as the university administration is necessary.

Similar to knowing which majors are more likely to go abroad, knowing which students are less likely to participate provides the opportunity to be intentional with programmatic efforts in attempt to encourage student participation. Data also provide the opportunity to examine other factors, which might negatively influence participation in study abroad. With some students of color, access might be an issue. Study abroad 
offices need to consider barriers to access and determine how to overcome them for students. Whether it is finances or not understanding the nature of a study abroad program, educating students on their opportunities and the value added of study abroad is necessary. With increasingly more interest, heritage study abroad might also be an important aspect in deciding to study abroad for some students. As more students want to reconnect with their cultural heritage, providing study abroad options outside of Western Europe might help increase the interest of some students.

One area where the results of the study provides interesting insight is study abroad as it relates to student athletes. While it is not a surprise that student athletes might not be able to go abroad due to their athletics commitments, it does create room for college and university leaders to be more intentional about creating opportunities and funding for student athletes to go abroad. With the growth of summer study abroad and short-term programs, student athletes should no longer be in a position to make a decision between the commitment to athletics and the choice to go abroad. The availability of short-term study abroad programs provides opportunities to go abroad without interrupting training schedules and athletics commitments.

Over the years, there have been many critiques of study abroad. Historically, the critiques of study abroad have focused on U.S. Imperialism but more recent they revolve around the consumerism of study abroad (Sharpe, 2015; Zemich-Bersin, 2007). As professionals strive to place students in overseas programs, it is important to focus on the benefits from participating in study abroad and experiencing a culture that differs from their own. It is up to the colleges and universities that promote study abroad to select 
programs which enhance their students' education and experience without selling-out on their standards and expectations.

One of the challenges that study abroad professionals face is a clear and concise definition for what they are trying to do. There is continual conversation surrounding globalizations, internationalization, and combinations of those words with intercultural. It is necessary, at least at the institutional level, to determine a concrete terminology base from which to work in order to more clearly align the goals of the post-secondary school. By knowing the intended outcome, colleges and universities are able to create plans on how they define global citizenry and how that goal is achieved.

At the institutional level, many things can be done to encourage participation in education abroad. In order to truly support a mission of globalization and creating quality international opportunities for students, post-secondary schools needs to provide the financial support to international initiatives. Financial support can be provided in a variety of mechanisms. First, post-secondary schools can ensure they have policies that allow their students to use financial aid to support their overseas opportunities. Next, they can work to provide scholarships to encourage and support student participation in overseas programs, especially for populations which are historically under-represented in education abroad participation. Scholarships could also be awarded to students as part of their recruitment to the college or university so the students know it is not only an expectation of their education, but that the financial support is made apparent when the student matriculates to the school. Finances would also support providing enough professional staff to ensure students receive the support they need to participate in 
overseas programs as well as dealing with international partners and the continual changes in health and safety issues abroad.

And while financial support from the institution is important, there are other ways for post-secondary school to provide support to students going overseas. There are policies and procedures schools can adopt to encourage student international program participation. In addition to the staff in the international center, faculty and staff can work as ambassadors across campus to encourage student participation in education abroad. Encouraging faculty to participate in international programs such as faculty-led programs, perhaps even including it in the tenure process, creates a greater investment on the part of the faculty is helping students find an opportunity to go overseas. In developing faculty-led programs, post-secondary schools that use staff as part of the support team for the faculty develop staff who have a better understanding of what to expect when students go overseas and how talk to them more in-depth about the benefits of an international experience as well as what to expect. Having staff who can work as emissaries of international education supports sharing the message of international experiences to a wider population of students.

Institutions can also support international education by integrating into the education requirements. Creating international educational components that could be satisfied through education abroad can be integrated into general education requirements or major and minor courses. By creating policies that allow international credits to transfer back more flexibly, students can be assured that studying abroad will not delay their degree completion. While the academic policies are helpful, programs with targeted populations should be a focus of post-secondary schools. Knowing more about who is 
not going abroad should encourage schools to create programs that engages those student populations. Short-term programs aimed at athletes, leadership development programs for students in fraternities and sororities, and research opportunities overseas are just a few ways post-secondary schools can engage students who might not think they can go abroad. With such a small percentage of American students going abroad, small changes to policies, focused institutional support, and an increase of financial support could generate great changes to encourage more students to go abroad.

\section{Recommendations for Research}

The next section introduces several aspects of the results. The first is looking at the limitations of the study. While some limitations were previously mentioned, it is important to understand the limitations of the study as they introduce new ideas for further study. The limitations also generate conversation about how practitioners can examine what they do in the field of study abroad and how they best serve their students and greater campus community.

\section{Limitations}

The current study has several limitations. While the data set is a nationwide data set, the majority of participating post-secondary schools were private colleges and universities. From this, one can conclude that the HERI data set is somewhat of an elite data set. The nationwide dataset based primarily on private post-secondary schools creates a challenge when trying to apply the results to their public post-secondary counterparts. Another limiting factor to the data set is that it is derived from a paid survey. Since colleges and universities are paying to administer the survey, bias is introduced into the results. The HERI data reported in the CSS and TFS do not provide an equivalent data set for those students at the colleges and universities who do not 
respond to the survey. Therefore, we do not know the participation rates, demographics, involvement, and academic characteristics of those who did not complete the survey.

Another limitation to the study is the large sample size; which makes it impossible to know more about the individual student experience as it relates to study abroad. However, Salisbury, An, and Pascarella (2013) indicate that often times study abroad research focuses only on small, post-secondary school populations which prevents generalizability; thus, a large dataset provides a new vantage point to study abroad research literature.

Other limitations to the study were the inability to study specific subpopulations on a campus. Given the small percentage of students of color in the sample, all nonWhite race/ethnicities had to be collapsed in order for the numbers to be sufficient enough to put into the model. The questions on the TFS and CSS also ask about sex in a binary male/female question. While this has been updated in more recent versions of the surveys, for the current study, it did not address gender identity. Also, important to note, whenever studying students who participate in Education Abroad, it is important to note that these students self-select into participation and therefore the study is not causal.

An important limitation to the study is Omitted Variable Bias. By knowingly not including information on student SES into the study, the results include bias as financial access is an important aspect of both post-secondary education as well as study abroad. The current data set did not allow to the use of SES data without violating the requirements of the logistic regression. 


\section{Future Research}

The study introduces the opportunity for further research. The first opportunity is to replicate the study at smaller level. A similar study at a single-institution offers the platform to examine how a post-secondary school can better provide study abroad opportunities for the specific student population. Through a single institution study the data are focused on a particular college or university, allowing for more precise interventions in order to increase study abroad participation. By also replicating the study at the single institution level, a college or university can better match the financial data to look at the influence financial needs plays into the decision to participate in study abroad. The single institution study also provides much greater insight into the students who do not participate. While student involvement may not always be able to be tracked, many of the other variables included in the study are available in admissions data. Single school studies can look at the participate/not participate in study abroad for their entire campus population for most of the variables included in the study. The single-school study introduces the chance for a mixed-methods study where the principal investigators can utilize quantitative data but also explore the students' experiences through qualitative inquiry.

Another opportunity for research is a mixed methods approach. The quantitative parts of the study come from the students' survey responses. By introducing the qualitative aspects of the study, researchers learn more about the individual student experiences and reflections. Questions in the study can be tailored to the students' duration abroad, how their involvement on campus influenced whether they participated in study abroad, how study abroad may influence their involvement on campus or 
selecting their major and provides a deeper understanding of study abroad and student identity. A mixed methods approach is probably easiest done in a single college or university study but has potential for a multischool study (similar to the Wabash National Study [Kuh et al., 1991]).

The opportunity for single institution study also allows for looking at when students study abroad. The CSS reports student actual participation, but not when the students went abroad. Knowing when students actually participate in study abroad can provide valuable insight into the major choices and involvement of students and whether participating in study abroad influenced students' decision to pursue a certain major or participate in an organization.

Twombly et al. (2012) believe that the choice to study abroad can be broken down into four categories: (1) Human capital; (2) Economic capital; (3) Social capital; and (4) Cultural capital. A study that integrates both the qualitative and quantitative data could provide greater insight into the decision to study abroad. And while a singleinstitution study is more feasible, a larger study which encompasses multiple universities and colleges (or even a nationwide study) would provide more tangible data for colleges and universities. Larger studies, such as the Wabash National Study, exist (Kuh et al., 1991).

Another data point not collected in the CSS is how long students went abroad. Duration of a study abroad program is of great interest to study abroad professionals. Knowing how long a student went abroad and the impact the experience has on their major selection, campus involvement, personal and cultural identity development are of great intrigue to professionals working with study abroad. And while studies exist that 
look at duration (such as Dwyer, 2004), there continues to be debate about the impact of duration versus experience.

A study that focuses only on private post-secondary schools or only on public school would be useful for study abroad professionals. In the HERI data set, there was a disproportionate number of private college or university participation. While the results are interesting, they are not necessarily applicable to a public college or university population. By breaking down a similar study by looking at the only the private or public post-secondary school data, study abroad offices in similar types of schools can use the results for a targeted approach to implement study abroad programs as well as marketing those programs to their campus population.

One area of interest in the results of the study is the likelihood of students who participate in IM/Club sports to study abroad. While NCAA/NAIA athletes are negatively associated with study abroad participation, another subpopulation of the campus is more likely to go abroad; students who intend to participate in IM/Club sports. With the findings, future study on students who are more involved with IM/Club sports might shed light into the students' motivations and increased intent to go abroad with this particular student subpopulation.

The existing literature demonstrates the challenge in assessing study abroad. Study abroad provides a historical perspective from pre-World War II, to post-Vietnam, to the modern world of post-9/11 (IIE, 2015; Twombly et al., 2012; Stearns, 2009; Schur, 2000). All of these world events have changed the experience and perception of education abroad. Even in today's society, the continual latent fear of terrorism continues to play into the decisions of many students and their families as to whether they 
will participate in education abroad. However, the existing research has significant gaps in what is known about education abroad. Studies that are single-institution or a cluster of similar type institutions lack widespread applicability. Research on study abroad can be from the student perspective or the faculty. There is the possibility for research that looks at student majors, duration abroad, gender, race/ethnicity, financial status, as well as their human/social/cultural/economic capital.

Education abroad can take on many different forms from actual study, to service learning, to internships. The vastness of each of these factors as they influence a student's decision to abroad as well as their experience while abroad. Even with all the factors, there is still the opportunity to study pre- and postexperience of the education abroad participant. Currently most studies focus on the poststudy abroad experience. However, with a pre/posttest model, there exists more opportunities for study and assessment on the impact on student self-actualization, personal growth, and future internship/job/graduate school placements. In designing a study, variable to consider for a study are duration of time abroad, how a students goes abroad, where the student studies, language of instruction, what the student does while abroad (study, intern, service, or a combination), student major(s) and minor(s), student characteristics (gender identity, race/ethnic identity, etc.), student SES, family/network support of participating in an abroad program, student cultural understanding, social/human/cultural capital, previous overseas studies (for credit or personal travel), whether they attend a private or public post-secondary school, their personal feelings toward going abroad and reflection on their experience, how it impacts their major upon return, expressing student identity situated in a foreign culture, and/or how an overseas experience impacts their internship 
opportunities, career goals, and employment. In consideration of study abroad participants, questions occur about whether they participate in study abroad more than once, pursue scholarships and academic opportunities abroad, and/or career opportunities overseas. There is the platform for research for colleges and universities that promote education abroad to determine the impact of the experience on their student retention/persistence and whether the experiences meet their preset expectations for graduating global citizens.

Other areas of research interest are in the opportunity to study student identity as it pertains to study abroad. Understanding how different races/ethnicities go through the decision process to go abroad as well as the actual study abroad is important to the understanding of the total student experience. The same inquiry can be said of students who identify as LGBTQ, students with differing abilities, various faiths, and other student identities. And while the conversation for the study started with student involvement, a student's identity can have great influence on what they choose to be involved in while in college. Even as we study gender as an identity, there are data and studies (McCollough, 2014; Bui, 2004; Grewel \& Kaplan, 2002) that demonstrate that male students are not studying abroad. Dedicated research would help provide insight into these phenomena that would help study abroad professionals encourage their male students to go abroad.

And while student identity is important in understanding the education abroad experiences, there are other areas of interest and concern in study abroad research. Duration is a continual conversation in study abroad. How long should a student go abroad to merit a worthwhile experience? Does a short-term program truly meet the 
intended goals of education abroad? Which also begs the question - what are the intended goals? Is the aim intercultural understanding? Marketability for employment? Creating global citizens? Helping students learn more about their heritage and culture? Language acquisition? Different programs are pursuing different outcomes from an education abroad experience. It is important to be intentional about stating the outcomes when planning the programs and/or organization. Colleges and university leaders need to be conscientious in these decisions as they devise international strategic plans. The focus of the program should influence how programs are established, which could impact long-term outcomes for any single-institutions studies.

Other factors that are of interest in research revolve around where students actually study while abroad. With some programs, students are enrolled in classes on-campus, but not integrated with students from the host college or university. Other programs students are integrated into the international classroom environment. And yet there are other programs where students never go into a classroom and the instruction is in the site visits with their faculty or program directors. Other factors influencing the education abroad experience, and worthy of study, are what type of program the student utilizes to go abroad. Most students study abroad either as a Direct Enroll, an exchange student, a program provider, or a faculty-led program. Some students are abroad on programs which are an extension of their own campus with faculty from their home college or university. What students do abroad can influence their decision to go abroad and eventually shapes their experience. While most students purse academic credit abroad, other students are opting to complete an internship or participate in community service. And another layer of the research is where students live while abroad. Most 
students live in either a residence hall, an apartment, or a homestay. However, some faculty programs may have students staying in hotels. Each of these details is pertinent to the research on the education abroad experience. Many existing education-abroad studies (Rust et al, 2008) focus on the students' experiences when they return. In order to have a better understanding of the changes that occur from an education abroad experience, researchers need to implement more pretest/posttest models. Using a pretest/posttest model will allow the researchers to see the changes that occurs from the specific time the students are abroad.

One other research area that has great potential for study abroad research is a longitudinal study. By tracking study abroad participants from before they go abroad, while abroad, once they return, throughout the rest of their college career, and into their post-undergraduate experience could provide great insight into the long-term impact education abroad. IES (Dwyer, 2004) conducted a long-term study with education abroad alumni from a nationwide data set. However, it does not include what the participants were like before they went abroad and how perhaps the time overseas had a long-term impact in graduate school and/or career choices.

While education abroad practitioners want to know more about the experiences and the transformational impact of education abroad, there are other important things to know as well. There needs to be focused research on why students say they want to go and yet usually do not participate. While there is limited research to indicate the reason is cost (Salisbury et al., 2011), there could be other factors as well. It would also be worthwhile to see if the various reasons stated for not going abroad continue to hold true. Historically, it was thought women went abroad because they would not have time when 
they became wives and mothers (Rouse, 2013) and men often state they do not go abroad due to time to degree (Twombly et al, 2012). Both quantitative and qualitative information would be helpful to gain better insight into the decision to not go abroad. While we discuss the longitudinal need for research on study abroad participants, the same can be said of nonparticipants. Does not going abroad in college impact their career aspirations or trajectories? Does it impact what they do in graduate school? Do they find the time to go abroad while in graduate school? Do they include international experiences in their personal lives? There are ample research opportunities to learn more about the students who do not participate in education abroad. By knowing more about the reasons why students do not go abroad, it could shed light on how to reduce the attrition of high school students who indicate they intend to go abroad in college but never do.

\section{Conclusion}

The results of the study found that different characteristics predict study abroad participation. Through the results from the TFS/CSS data set, it was confirmed that White women are more likely to go abroad. However, the data indicated students who are pursuing STEM majors are more likely to go abroad which is a break from historical trends. The results support that that students attending private colleges and universities are still more likely to go abroad. And while there exists a great amount of attrition from high school seniors and college first-year students who intend to go abroad, we know that intent to go abroad is the single most likely predictor that a student will actually participate in an overseas program. The findings also indicate that students who demonstrate greater high school academic achievement are more likely to go abroad. 
While the prediction for the study was that students who intend to be involved are more likely to go abroad, the findings indicate that this is not always the case. Students who are NCAA/NAIA athletes and students working on faculty research are less likely to study abroad. Student intent to be involved in Greek life and student government had differing results on the actual participation on study abroad based on whether the model only looked at intent or if they model looked at all the variables together. The same is said of intent to be involved with clubs and organizations. However, intent to participate in Club/IM sports positively predicted study abroad participation.

Ultimately, there are many opportunities for further study in order to better understand how and why students go abroad, what they experience, and how they get to the decision to go abroad in the first place. Knowing there is ample opportunity for continued research in education abroad creates the chance for others interested in the field to add to and further the field of literature. And through the findings of existing and future research, college and university leaders will continue to create opportunities for their students; hopefully meeting the demands of and preparing our students for an increasingly globalized society. 


\section{REFERENCES}

Adelman, C. (2004). Principal indicators of student academic histories in postsecondary education, 1972-2000. Washington, DC: U.S. Department of Education, Institute of Education Sciences.

Adelman, C. (2006). The toolbox revisited: Paths to degree completion from high school through college. Washington, D.C.: Department of Education. Retrieved on January 21, 2019 from https://www2.ed.gov/rschstat/research/pubs/toolbox revisit/toolbox.pdf

Alfano, H. J., \& Edjulee, N. (2013). Differences in work, levels of involvement, and academic performance between residential and commuter students. College Student Journal, 47(2), 334-342.

American Council on Education (ACE), Art \& Sciences Group LLC, \& College Board. (2008). College bound students' interest in study abroad and other international learning activities. Retrieved on January 21, 2019 from http://www.acenet.edu/news-room/Documents/2008-Student-Poll.pdf

American Psychological Association (2011). Definition of term: Sex, gender identity, sexual orientation. The guidelines for psychological practice with lesbian, gay, and bisexual clients. Retrieved on January 21, 2019 from http://www.apa.org/pi/lgbt/resources/sexuality-definitions.pdf

Anderson, P. H., Lawton, L., Rexiesen, R. J., \& Hubbard, A. C. (2006). Short-term study abroad and intercultural sensitivity: A pilot study. International Journal of Intercultural Relations, 3, 457-469.

Association for International Educators (NAFSA). (2012). About NAFSA. Retrieved on January1, 2019 from http://www.nafsa.org/about/default.aspx

Astin, A. W. (1968). College environment. Washington, DC: American Council on Education.

Astin, A. W. (1975). Preventing students from dropping out. San Francisco, CA: Jossey-Bass.

Astin, A. W. (1977). Four critical years. San Francisco, CA: Jossey-Bass. 
Astin, A. W. (1984). Student involvement: A developmental theory for higher education. Journal of College Student Personnel, 25, 297-308.

Astin, A. W. (1985a). Achieving educational excellence. San Francisco, CA: JosseyBass.

Astin, A. W. (1985b). Involvement: The cornerstone of excellence. Change, 17, 34-39.

Astin, A. W. (1991). Assessment for excellence. New York, NY: American Council on Education/Macmillan.

Astin, A. W. (1993). Assessment for excellence ( $2^{\text {nd }}$ ed.). Phoenix, AZ: American Council on Education and The Oryx Press.

Astin, A. W. (1997). How "good" is your institution's retention rate? Research in Higher Education, 38, 647-658.

Astin, A. W. (1999). Student involvement: A developmental theory for higher education. Journal of College Student Development, 40, 518-529.

Astin, A. W. (2003). Studying how college affects students: A personal history of CIRP. About Campus, 8, 21-28.

Astin, A. W. (2005-2006). Making sense out of degree completion rates. Journal of College Student Retention, 71, 5-17.

Astin, A. W. \& Antonio, A.L. (2012). Assessment for excellence: The philosophy and practice of assessment in higher education ( $2^{\text {nd }}$ ed). Lanham, MD: Rowman and Littlefield Publishers, Inc.

Astin, A. W., \& Sax, L. J. (1998). How undergraduates are affected by service learning. Journal of College Student Development, 39, 251-263.

Atkinson, R. C., \& Geiser, S. (2009). Reflections on a Century of College Admissions Test. Feature, 38, 665-676. Downloaded January 21, 2019 from http://journals.sagepub.com/doi/pdf/10.3102/0013189X09351981

BaileyShea, C. (2009). Factors that affect American college students' participation in study abroad. Doctoral dissertation. University of Rochester, NY. Retrieved on January 21, 2019 from https://search.proquest.com/pqdtglobal/docview/89198123/ 9A449D24030445E4PQ/1? accountid=14665

Bellamy, C., \& Weinberg, A. (2006, Fall). Creating global citizens through study abroad. New England Board of Higher Education Connections, p. 20. 
Benson, A. (2004). Research tourism: Professional travel for useful discoveries. In M. Novelli (Ed.). Niche tourism: Contemporary issues, trends, and cases, (pp.133-142). Oxford, England: Taylor and Francis Publishing Company.

Bower, A. M., \& Inkeles, K. K. (2010). Living-learning programs: One high-impact education practice we know a lot about. Liberal Education, 96, 36-43.

Braskamp, L. A., \& Engberg, M. E. (2011). How colleges can influence the development of global perspective. Liberal Education, 97, 35-39.

Brecht, R. D., Davidson, D. E., \& Ginsberg, R. B. (1995). Predictors of foreign language gain during study abroad. In B. F. Freed (Ed.). Second language acquisition in a study abroad context, (pp. 37-66). Philadelphia, PA: John Benjamins Publishing Company.

Brickman, W. (1965). Historical development in government interest in international higher education. In S. Fraser (Ed.). Governmental policy and international education, (pp. 17-46). New York, NY: John Wiley \& Sons, Inc.

Bringle, R. G., \& Hatcher, J. A. (1996). Implementing serving learning in higher education. Journal of Higher Education, 67, 221-239.

Brownell, J. E., \& Swaner, L. E. (2009). High-impact practices: Applying the learning outcomes literature to the development of successful campus programs. Peer Review, 11, 26-30.

Brux, J. M., \& Fry, B. (2010). Multicultural students in study abroad: Their interests, their issues and their constraints. Journal of Studies in International Education, $14,508-527$.

Budd, J. (1990). Higher education literature: Characteristics of citation patterns. Journal of Higher Education, 71, 223-246.

Bui, Q. (2014, October 28). Who studies what? Men, women, and college majors [blog]. Retrieved on January 21, 2019 from https://www.npr.org/sections/money/2014/10/28/359419934/who-studies-whatmen-women-and-college-majors

Carini, R. M., Kuh, G. D., \& Klein, S. P. (2006). Student engagement and student learning: Testing the linkages. Research in Higher Education, 47, 1-32.

Carlson, J. S., \& Widaman, K. F. (1988). The effects of study abroad during college on attitudes towards other cultures. International Journal of Intercultural Relations, $12,1-17$. 
Case, K. F. (2011). A gendered approach on student involvement in collegiate clubs and organizations in Christian higher education (doctoral dissertation). Proquest Dissertations \& Thesis Global. DOI: 10.1080/15363759.2011.576208.

The Center for Global Education: An International Resource Center. (2011). Impact of study abroad on retention and success. Retrieved on February 4, 2019 from http://globaledresearch.com/study-abroad/impact.asp

Chickering, A. W., \& Gamson, Z. F. (1987). Seven principles for good practice in undergraduate education. AAHE Bulletin, 39, 3-7.

Creswell, J. W. (2012). Educational research: Planning, conducting, and evaluating quantitative and qualitative research ( $4^{\text {th }}$ ed.). Upper Saddle River, NJ: Merrill.

Daly, H. E. (1999). Globalization versus internationalization, Global Policy Forum, Retrieved on January 21, 2019 from: https://www.globalpolicy.org/component/content/article/162/27995.html

DeWit, H. (2009). Global citizenship and study abroad: A European comparative perspective. In R. Lewin (Ed.), The handbook of practice and research in study abroad: Higher education and the quest for global citizenship (pp. 212-229). New York, NY: Routledge.

Doan, J. (2011). The Impact of Campus Climate and Student Involvement on Students of Color. The Vermont Connection, 32, 32-39.

Retrieved on November 24, 2019 from https://scholarworks.uvm.edu/cgi/viewcontent.cgi?article=1113\&context=tvc

Dolby, N. (2004). Encountering an American self: Study abroad and national identity. Comparative Education Review, 150-172.

Duzny, K. (2014). Don't give into the pressure to study abroad. The GW Hatchet. Retrieved on January 21, 2019 from https://www.gwhatchet.com/2014/11/17/kirby-dzurny-dont-give-in-to-thepressure-to-study-abroad/

Dwyer, M. M., \& Peters, C. K. (2004). Benefits of study abroad: New study confirms significant gains [web article]. Retrieved on January 21, 2019 from http://www.transitionsabroad.com/publications/magazine/0403/benefits_study_ab road.shtml

Dwyer, M. M. (2004). More is better: The impact of study abroad program duration. Frontiers: The Interdisciplinary Journal of Study Abroad, 10, 151-163. 
Engle, L., \& Engle, J. (2004). Assessing language acquisition and intercultural sensitivity development in relation to study abroad program design. Frontiers: The Interdisciplinary Journal of Study Abroad, 10, 219-236.

Farrell, E. F. (2007). Study abroad blossoms into big business. Chronicle of Higher Education. Retrieved on January 21, 2019 from http://chronicle.com/article/Study-Abroad-Blossoms-Into-Big/19935

Fischer, K. (2008). Code of ethics proposed for study-abroad programs. Chronicle of Higher Education. Retrieved on January 21, 2019 from http://chronicle.com/article/Code-of-Ethics-Is-Offered-to/558/

Fischer, K. (2009). Short study-abroad trips can have lasting effect, research suggests. Chronicle of Higher Education. Retrieved on January 21, 2019 from http://chronicle.com/article/Short-Study-Abroad-Trips-Can/1541

Folsom, J. S., Osborne-Lampkin, L., \& Herrington, C. D. (2014). Using administrative data for research: A companion guide to a descriptive analysis of the principal workforce in Florida schools. IES National Center for Education Evaluation and Regional Assistance. Institute of Educational Sciences-U.S. Department of Education. Retrieved on January 21, 2019 from http://files.eric.ed.gov/fulltext/ED551066.pdf.

Forum on Education Abroad. (2011). Education abroad glossary ( $2^{\text {nd }}$ ed.), The forum on education abroad: Pennsylvania. Retrieved on January 21, 2019 from http://apps.forumea.org/EducationAbroadGlossary2ndEdition2011.cfm

Freed, B. F. (1995). What makes us think that students who study abroad become fluent? In B.F. Freed (Ed.), Second language acquisition in a study abroad context, (pp.123-148). Philadelphia, PA: John Benjamins Publishing Company.

Fulbright. (n.d.-a). History. Retrieved February 4, 2019 from http://us.fulbrightonline.org/about/history

Fulbright: Fulbright Scholar Program. (n.d.-b). Retrieved on January 21, 2019 from http://www.cies.org/about-us/about-cies

Goldin, C., Katz., L., \& Kuziemko, I. (2006). The homecoming of American college women: The reversal of the college gender gap. The Journal of Economic Perspectives, 20, 133-156.

Retrieved on November 24, 2019 from: https://www.jstor.org/stable/pdf/30033687.pdf?refreqid=excelsior\%3A26fc497f7 $92 \mathrm{fc} 7 \mathrm{cf} 6 \mathrm{a} 582274 \mathrm{e} 1814 \mathrm{~b} 5 \mathrm{e}$

Gray, K. S., Murdock, G. K., \& Stebbins, C. D. (2002). Assessing study abroad's effect on an international mission. Change, 34, 44-51. 
Grewel, L., \& Kaplan, C. (2002). Voice of gender role conflict: The social construction of college men's identity. Journal of College Student Development, 43, 508-521.

Hamir, H. B. (2011). Go abroad and graduate on-time: Study abroad participation, degree completion, and time-to-degree. (Unpublished doctoral dissertation). University of Nebraska-Lincoln. Retrieved on January 21, 2019 from http://digitalcommons.unl.edu/cgi/viewcontent.cgi?article= $1065 \&$ context $=$ cehsedaddiss

Harley, D. A., Jolivette, K., McCormick, K., \& Tice, K. (2002). Race, class, and gender: A constellation of positionalities with implications for counseling. Journal of Multicultural Counseling and Development, 30, 216-238.

Harrison, K. C., Comeaux, E., \& Plecha, M. (2006). Faculty and male football players on university campuses. Research Quarterly for Exercise and Sport, 77, 277-284.

Helms, J. E., \& Cook, D. A. (1999). Using race and culture in counseling and psychotherapy: Theory and process. Boston, MA: Allyn and Bacon.

Higher Education Research Institute (HERI) (2015) home of Cooperative Institute Research Program (CIRP) (2015) College Senior Survey Retrieved on January 21, 2019 from http://www.heri.ucla.edu/cssoverview.php

Higher Education Research Institute (HERI) (2009) home of Cooperative Institute Research Program (CIRP). (2009). CIRP Constructs. Retrieved on February 4, 2019 from https://heri.ucla.edu/cirp-constructs/

The History of NAFSA: Association of International Educators. (n.d.). Retrieved on January, 21, 2019 http://www.nafsa.org/Learn_About_NAFSA/History/

Hoffa, W. (2007). A History of U.S. study abroad: Beginnings to 1965. A Special Publication of Frontiers: The Interdisciplinary Journal of Study Abroad and The Forum on Education Abroad. Lancaster, PA.

Hopkins, R. J. (1999). Studying abroad as a form of experiential education. Liberal Education, 85(3), 36-42.

Horn, A. S. (2013). Educative conditions for prosocial value development during college. Doctoral dissertation. University of Minnesota, MN. Retrieved on February 4, 2019 from http://search.proquest.com/pqdtglobal/docview/ 1469008509/CFCCC9AFF1FA418FPQ/3? accountid=14665

House, J. D. (2002). The independent effects of student characteristics and instructional activities on achievement: An application of the input-environment-outcome assessment model. International Journal of Instructional Media, 29, 225-239. 
House, J. D. (2006). Using the college student survey to assess student perceptions and achievement. Assessment Update, 18, 7-9.

Hudzik, J. K. (2011). Comprehensive internationalization: From concept to action. Association for International Educators: Washington, D.C. Retrieved on January 26, 2019 from http://www.nafsa.org/_/File/_/downloads/cizn_concept_action.pdf

Huebner, R. (1995). The effects of overseas language programs: Report on the case study of an intensive Japanese course. In B.F. Freed (Ed.), Second language acquisition in a study abroad context, (pp.171-194). Philadelphia, PA: John Benjamins Publishing Company.

Huebner, T. (1998). Methodological considerations in data collection for language learning in a study abroad context. Frontiers: The Interdisciplinary Journal of Study Abroad, 4, 1-30.

Institute on International Education. (n.d.). A Brief History of IIE. Retrieved on January 21, 2019 from https://www.iie.org/Why-IIE/History

Institute on International Education (IIE). (2009). Promoting study abroad in science and technology fields (white paper). Retrieved on January 21, 2019 from https://www.iie.org/Research-and-Insights/Publications/Promoting-StudyAbroad-in-Science-and-Technology-Fields

Institute on International Education (IIE). (2015). Profile on U.S. study abroad students, from 2003/04 to 2013/14. Open Doors Report on International Education Exchange. Retrieved on January 21, 2019 from http://iie.org/opendoors

Institute on International Education (IIE). (2014). Fast Facts. Research \& Insights. Retrieved on February 27, 2019 from_https://www.iie.org/Research-andInsights/Open-Doors/Fact-Sheets-and-Infographics/Fast-Facts

Integrated Post-secondary Education Data System. (2014). Definitions for new race and ethnicity categories. Retrieved on January 21, 2019 from https://nces.ed.gov/ipeds/report-your-data/race-ethnicity-definitions

IU News Room. (2009, September). New data from the IU Office of Overseas Study contradict study abroad myths. Retrieved on January 21, 2019 from http://newsinfo.iu.edu/news/page/normal/11815.html

Jaschik, S. (2015, January 20). Well-prepared in their own eyes. Inside Higher Education, Retrieved on January 21, 2019 from https://www.insidehighered.com/news/2015/01/20/study-finds-big-gaps-betweenstudent-and-employer-perceptions 
Jessup-Anger, J. E. (2008). Gender observations and study abroad? How student reconcile cross-cultural differences related to gender. Journal of College Student Development, 49, 367-373.

Jones, S. R., Rowan-Kenyon, H. T., Ireland, S. M., Neihaus, E., \& Skendall, K. C. (2012). The meaning students make as participants in short-term immersion program. Journal of College Student Development, 53, 201-220.

Kean, T., \& Hamilton, L. (2008). Send more U.S. students abroad. Christian Science Monitor. Retrieved on January 21, 2019 from http://www.csmonitor.com/2008/0612/p09s01-coop.html

Kehl, K. \& Morris, J. (2007-2008). Differences in global mindset between short-term and semester-long study abroad participants as students at private universities. Frontiers: The Interdisciplinary Journal of Study Abroad, 15, 67-79.

Kerr, C. (1994). Troubled times for American higher education: The 1990s and beyond. Albany, NY: State University of New York Press.

Kerr, C. (1994). Higher education cannot escape history: Issues for the twenty-first century. Albany, NY: State University of New York Press.

Kezar, A., \& Kinzie, J. (2006). Examining the ways institutions create student engagement: The role of mission. Journal of College Student Development, 47, 149-171.

Kitsansis, A. (2004). Studying abroad: The role of the college students' goals on the development of cross-cultural skills and global understanding. College Student Journal, 38, 441-452.

Kochanek, S. (1998). Study abroad celebrates $75^{\text {th }}$ anniversary. Retrieved from on January 21, 2019 http://www.udel.edu/PR/SpecialUDelivery/vol1no1/anniversary.html

Knight, J. (2004). Internationalization remodeled: Definition, approaches, and rationales. Journal of Studies in International Education, 8, 5-31. doi:10.1177/1028315303260832

Knight, J. (2014). Internationalization of education. elButlleti, vol 75. Retrieved on January 21, 2019 from: http://www.aqu.cat/elButlleti/butlleti75/articles1_en.html\#.WI46-VMrJdg 
Krauth, S. A. (2011). Service participation as a predictor of multicultural competency in college graduates: A comparative study of sectarian and nonsectarian institutions. Doctoral dissertation. Iowa State University, IA. Retrieved on January 21, 2019 from https://lib.dr.iastate.edu/cgi/viewcontent.cgi?referer=https://www. google.com/\&httpsredir=1\&article=1397\&context=etd

Kuh, G. D. (2007). What student engagement data tell us about college readiness. Peer Review, 9, 4-8.

Kuh, G. D. (2008). High-impact educational practices: What they are, who has access to them, and why they matter. Washington, DC: LEAP American Association of College and Universities.

Kuh, G. D., Kinzie, J., Schuh, J. H., Whitt, E. J., \& Associates. (2005). Student success in college: Creating conditions that matter. San Francisco, CA: Jossey-Bass.

Kuh, G. D., Schuh, J. S., Whitt, E. J., \& Associates. (1991). Involving colleges: Successful approaches to fostering student learning and personal development outside the classroom. San Francisco, CA: Jossey-Bass.

LaNassa, S. M., Olson, E., \& Alleman, N. (2007). The impact of on-campus student growth on first-year student engagement and success. Research in Higher Education, 48, 941-966.

Landau, J., \& Moore, D. C. (2001). Toward reconciliation in the motherland: Race, class, nationality, gender, and the complexities of American students' presences at the University of Ghana, Legon. Frontiers: The Interdisciplinary Journal of Study Abroad, 12, 25-59.

Lane-Toomey, C. (2014). U.S. government factors influencing an expansion of study abroad in the Middle East/North Africa. Frontiers: The Interdisciplinary Journal of Study Abroad, 24, 121-140.

Lincoln Commission. (2005). Global competence and national needs: One million Americans studying abroad. Final report from the Commission on Abraham Lincoln Fellowship Program, Washington, D.C.

Lopatto, D. (2010). Undergraduate research as a high-impact student experience. Peer Review, 12.2, 27-30.

Love, P. G., \& Estanek, S. M. (2004). Rethinking student affairs practice. San Francisco, CA: Jossey-Bass.

Malmgren, J., \& Galvin, J. (2008). Effect of study abroad participation on student graduation rates: A study of three incoming freshman cohorts at the University of Minnesota, Twin Cities. NACADA Journal, 28, 29-42. 
Martin, A. J., Wilson, R., Liem, G. A, \& Ginns, P. (2013). Academic momentum at university/college: Exploring the roles of prior learning, life experience, and ongoing performance in academic achievement across time. The Journal of Higher Education, 84, 640-674.

McCabe, L. T. (2001). Globalization and internationalization: The impact on education abroad programs. Journal of Studies in International Education, 5, 138.

McCollough, R. (2014, November 24). Men are from STEM, women from humanities: Breaking down gender barriers in academia [blog]. Retrieved on February 4, 2019 from https://www.unlvfreepress.com/men-are-from-stem-women-are-fromhumanities-breaking-down-gender-barriers-in-academia/

McMillan, A. R., \& Opem, G. (2009). Study abroad: A lifetime of benefits. Abroad View Magazine 1, Retrieved on January 21, 2019 from http://www.iesabroad.org/study-abroad/news/study-abroad-lifetime-benefits

McMurtrie, B., \& Fischer, K. (2008, June 6). Red tape is top concern for international educators. The Chronicle of Higher Education. Retrieved on January 21, 2019 from http://chronicle.com/article/Red-Tape-Is-a-Top-Concern-for/29674

Merril, K. C., Braskamp, D. C., \& Braskamp, L. A. (2012). Assessing individuals' global perspective. Journal of College Student Development, 53, 356-360.

Metzger, C. A. (2006). Study abroad programming: A $21^{\text {st }}$ century retention strategy? College Student Affairs Journal, 25, 164-175.

Miller, R., Rycek, R., \& Friston, K. (2011). The effect of high-impact learning experiences on student engagement. Procedia Social and Behavioral Services, 5, 53-59.

NAFSA Diversity Statement. (2005, June 23). Retrieved on January 21, 2019 from https://www.nafsa.org/About_Us/About_NAFSA/Mission_and_Vision/NAFSA_ Diversity_and_Inclusion_Statement/

National Survey on Student Engagement. (2007). Experiences that matter: Enhancing student learning and success. Annual Report 2007. Center for Post-secondary Research: Bloomington, IN.

Neff, A. R. (2001). Discovering heritage and more by studying abroad. Black Issues in Higher Education, 18, 38.

Nesheim, B. E., Guentzel, M. J., Kellog, A. H., McDonald, W. M., Wells, C. A., \& Whitt, E. J. (2007). Outcomes for students of student affairs-academic affairs partnerships. Journal of College Student Development, 48, 435-454.

Osborne, J. W. (2015). Best practices in logistic regression. Thousand Oaks, CA: Sage. 
Paige, R. M., Fry, G. W., Stallman, E. M., Josic, J., \& Jon, J. (2009). Study abroad for global engagement: The long-term impact of mobility experiences. Intercultural Education, 20, S29-44.

Pascarella, E. T., \& Terenzini, P. T. (2005). How colleges affect students: A third decade of research. San Francisco, CA: Jossey-Bass.

Paul Simon Public Policy Institute. (2013). Retrieved on January 21, 2019 from http://paulsimoninstitute.org/index.php?option=com_content\&view=category\&la yout $=$ blog\&id= $=88 \&$ Itemid $=264$

Perna, L. (2008). Understanding high school students' willingness to borrow to pay for college prices. Research in Higher Education, 49, 589-606.

Pike, G. R. (2006). The convergent and discriminant validity of CSS scalelet scores. Journal of College Student Development, 47, 551-564.

Redden, E. (2010, July 13). Academic outcomes of study abroad. Inside Higher Ed. Retrieved on January 21, 2019 from https://www.insidehighered.com/news/2010/07/13/abroad

Rogers, J. (2014, September 22). Why don't men go overseas? Go Overseas Retrieved from http://gooverseas.com/blog/why-men-do-not-study-abroad

Rouse, C. (2013, October 16). Study abroad survey shows prices still big factor: Ragan intent on opening foreign study up to entirety of student body. The Knox student. Retrieved on January 21, 2019 from

http://theknoxstudent.com/new/2013/10/16/study-abroad-survey-show-price-stillbig-factor

Ruel, H. (Director). (2013, November 22). Diplomacy means business. Inauguration. Lecture conducted from Windesheim University of Applied Sciences at Zwolle, Zwolle.

Rust, V., Dhanatya, C., Futuro, L. H., \& Kheiltash, O. (2008). Student involvement as predictive of college freshman plans to study abroad. Frontiers: The Interdisciplinary Journal of Study Abroad, 15, 1-16.

Salisbury, M., An, B., \& Pascarella, E. T. (2013). The effect of study abroad on intercultural competence among undergraduate college students. Journal of Student Affairs Research and Practice, 50, 1-20.

Salisbury, M., Paulsen, M., \& Pascarella, E. T. (2010). To see the world or stay at home: Applying an integrated student choice model to explore the gender game in the intent to study abroad. Research in Higher Education, 51, 615-640. 
Salisbury, M., Paulsen, M., \& Pascarella, E. T. (2011). Why do all the study abroad students look alike? Applying an integrated student choice model to explore differences in the factors that influence White and minority students' intent to study abroad. Research in Higher Education, 52, 123-150.

Salisbury, M., Umbach, P., Paulson, M., \& Pascarella, E. T. (2009). Going global: Understanding the choice process of the intent to study abroad. Research in Higher Education, 50, 119-143.

Savicki, V., \& Cooley, E. (2011). American identity in study abroad students: contrasts, changes, correlates. Journal of College Student Development, 52, 339-349.

Schock, L. (2012, June 11). Advancing global engagement through international education (NAFSA). Retrieved on January 21, 2019 from http://blog.nafsa.org/2012/06/11/advancing-global-engagement-throughinternational-education/\#more-3814

Schur, J. (2002). Founding documents of the Peace Corps. Constitution Community: Postwar United States (1945 to Early 1970's). Retrieved on January 21, 2019 from http://www.archives.gov/education/lessons/peace-corps/

Senator Paul Simon Act. (2013). Retrieved on January 21, 2019 from https://paulsimoninstitute.siu.edu/focus-interests/study-abroad-act.php

Sharp, E. (2015). Colonialist tendencies in education abroad. International Journal of Teaching and Learning in Higher Education, 27, 227-234. Retrieved on September 19, 2019 from https://files.eric.ed.gov/fulltext/EJ1082881.pdf

Shavelson, R. J. (1996). Statistical reasoning for the behavioral sciences. Boston, MA: Allyn and Bacon.

Spring, J. (2015). Globalization of education: An introduction. New York, NY: Routledge.

Stearns, P. (2009). Educating global citizens in college and universities. New York, NY: Routledge.

Sternberg, M. (2002, Winter). "Involve me and I will understand": Academic quality in experiential programs abroad. Frontiers: The Interdisciplinary Journal for Study Abroad, 8, 207-228.

St. John, E., Rowley, L., \& Hu, S. (2009). Diversity and leadership: A study of highachieving student of color. Journal of Negro Education, 79, 17-28.

Retrieved on November 24, 2019 from https://www.jstor.org/stable/25608715?seq=1\#metadata_info_tab_contents 
Stoltzfus, J. (2011, October). Logistic regression: a brief primer. Academic Emergency Medicine, 18, 1099-104. Retrieved on February 24, 2019 from https://onlinelibrary.wiley.com/doi/full/10.1111/j.1553-2712.2011.01185.x

Stroud, A. H. (2010). Who plans (not) to study abroad: An examination of U.S. student intent. Journal of Studies in International Education, 14, 491-507.

Stuart, R. (2007). Stepping up to study abroad. Diverse issues in higher education, 24, 16-19. Study Abroad for Global Engagement (2009). SAGE: Beyond immediate impact-study abroad for global engagement, 2009. Retrieved on January 21, 2019 from https://www.researchgate.net/publication/232962244_Study_abroad_for_global_ engagement_The_long-term_impact_of_mobility_experiences

Sutton, R. C., \& Rubin, D. L. (2004). The GLOSSARI project: Initial findings from a system-wide research initiative on study abroad learning outcomes. Frontiers: The Interdisciplinary Journal for Study Abroad, 10, 65-81.

Sutton, R. C., \& Rubin, D. L. (2010, June). Documenting the academic impact of study abroad: Final report of the GLOSSARI project. Paper session presented at the NAFSA Annual Conference, Kansas City, MO.

Tallentire, S. (2015). Risk factors impacting resiliency outcomes for historically vulnerable college students. Doctoral dissertation. University of LaVerne, CA. Retrieved on February 4, 2019 from http://search.proquest.com/pqdtglobal/docview/1714093835/B39874424834E0DP Q/1? accountid=14665

Thurmond, V. A., \& Popkess-Wawter, S. (2001). Examination of a middle range theory: Applying Astin's Input-Environment-Output (I-E-O) model to web-based education. Online Journal of Nursing Informatics, 7(2). Retrieved on January 21, 2019 from http://ojni.org/7_2/thurmond.htm

Tinto, V. A. (1987). Leaving college: Rethinking the causes and cures of student attrition. Chicago, IL: University of Chicago Press.

Tinto, V. A. (1993). Leaving college: Rethinking the causes and cures of student attrition ( $2^{\text {nd }}$ ed.). Chicago, IL: University of Chicago Press.

Twombly, S. B., Salisbury, M. H., Tumanut, S. D., \& Klute, P. (2012). Study abroad in a new global century: Renewing the promise, refining the purpose. ASHE Higher Education Report, 38.

University Planning, Institutional Research, and Accountability. (2009). Plans, participation and outcomes: Overseas study at Indiana University Bloomington. Retrieved on February 4, 2019 from https://overseas.iu.edu/docs/UIRR_Overseas_Study.pdf 
Volkwein, J. F., \& Sweitzer, K. V. (2006). Institutional prestige and reputation among research universities and liberal arts colleges. Research in Higher Education, 47, $129-148$.

Ward, H. H. (2015). Internationalization in action: Internationalizing the co-curriculum. American Council on Education, 1-24. Retrieved on January 21, 2019 from https://www.acenet.edu/news-room/Documents/Intlz-In-Action-Intlz-CoCurriculum-Part-1.pdf

Webber, K. L., Krylow, R. B., \& Zhang, Q. (2013). Does involvement really matter? Indicators of college student success and satisfaction. Journal of College Student Development, 54, 591-611.

Willis, T. (2015). “And still we rise...”: Microaggressions and intersectionality in the study abroad experiences of Black women. The Interdisciplinary Journal of Study Abroad, XXVI, 209-230.

Retrieved on November 24, 2019 from:

https://files.eric.ed.gov/fulltext/EJ1084443.pdf

Wolf-Wendel, L., Ward, K., \& Kinzie, J. (2009). A tangled web of terms: The overlap and unique contribution of involvement, engagement, and integration to understanding college student success. Journal of College Student Development $50,407-428$.

Young, D. (2007-2008). Persistence at a liberal arts university and participation in a study-abroad program. Frontiers: The Interdisciplinary Journal of Study Abroad. $\mathrm{XV}$.

Zemich-Bersin, Talya. (2007). Global citizenship \& study abroad: It's all about the U.S. Critical Literacy: Theories and Practice, 1, 16-29. Retrieved on September 19, 2019 from http://www.criticalliteracyjournal.org/cljournalissue2volume1.pdf\#page=16 


\section{APPENDIX A: COLLEGE SENIOR SURVEY}

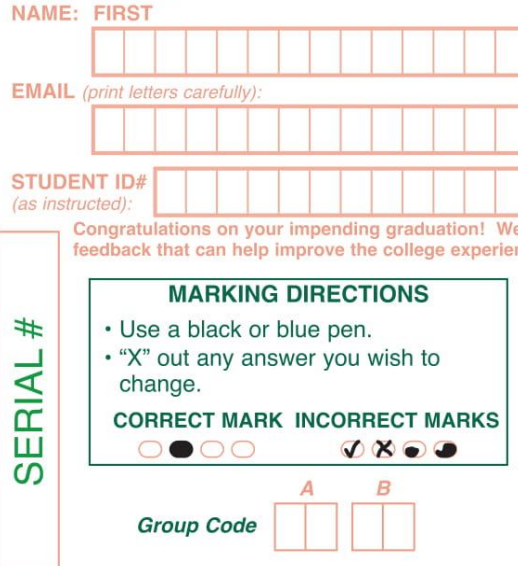

1. Your sex: $\bigcirc$ Female $\bigcirc$ Male

2. How often in the past year did you: (Mark one in each row)

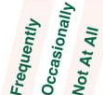

Ask questions in class (F) (1) (II)

Support your opinions with a logical argument, (F) (O) (1) Seek solutions to problems and explain them to others...

Revise your papers to improve your writing... Evaluate the quality or reliability of information you received.........

Take a risk because you felt you had more to gain

Seek alternative solutions to a problem ............

Look up scientific research articles and

resources.................................................

Explore topics on your own, even though it

was not required for a class....................

process.

Seek feedback on your academic work .........

Integrate skills and knowledge from different

sources and experiences

3. What year did you

first enter: (Mark

one in each column)

2012 or 2013

4. Please indicate your enrollment status below: (Mark one)

2011.

Full-time

2010.

undergraduate

Part-time undergraduate

2008 or earlier ......... $\bigcirc$

Not enrolled

5. Expected Graduation Date: $\bigcirc 2012 \bigcirc$ Other

$$
2013 \bigcirc \text { Not sure }
$$

6. How would you characterize your political views? (Mark one)

$\bigcirc$ Far left $\bigcirc$ Middle-of-the-road $\bigcirc$ Conservative

Liberal

Far right

7. Are you currently registered to vote?

$$
\bigcirc \text { Ineligible } \bigcirc \text { Yes } \bigcirc \text { No }
$$

8. Are you a veteran? $\bigcirc$ Yes $\bigcirc$ No

$\perp$
III LAST

\section{\begin{tabular}{|l|l|l|l|l|l|l|l|l|l|l|l|l|l|l|l|l|}
\hline & & & & & & & & & & & & & & & & \\
\hline
\end{tabular}}

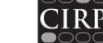

When were you born?

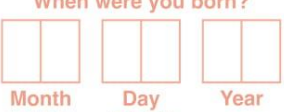

(01-12) (01-31)

ery interested in your experiences as a college student. This form has been designed to provide

9. Since entering college, indicate how often you:

(Mark one in each row)

Worked on independent study

projects.

Discussed course content with students outside of class.

Have been a guest in a

professor's home

Failed to complete homework

on time.

Have been bored in class.

Came late to class..................... (F) (D) (i)

Studied with other students........ (F) (D) (II)

Performed community service

as part of a class.

Voted in a student election

Posted on a course-related

on-line discussion board

Used the library for research

or homework

Accessed your campus' library

resources electronically....

Missed class due to employment. (F) (O) (II)

Missed class for other reasons.... (F) (C) (N)

Tutored another college student... (F) (C) (I)

Met with an advisor/counselor

about your career plans ........... (F) (C) (1)

Fell asleep in class ..................... (F) (D) (I)

Had difficulty getting the

courses you needed....

Asked a professor for advice

after class..

Demonstrated for a cause (e.g.

boycott, rally, protest).

Challenged a professor's

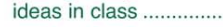

Worked on a professor's

research project ........

Communicated regularly with

your professors ..................... (F) (C) (N)

Worked with classmates on

group projects:

During class

Outside of class

Took a class that required:

One or more $10+$ page papers. (F) (C) (N)

Multiple short papers............... (F) (C) (11)

Made a presentation in class ..... (F) (0) (N)

Contributed to class discussions.. (F) (D) (NI)

Helped raise money for a cause

or campaign .

Publicly communicated your

opinion about a cause (e.g.

blog, email, petition)...

10. Since entering college have you:

(Mark yes or no for each item)

(1) (II) Joined a social fraternity or sorority

(1) (N) Failed one or more courses

(1) (N) Held a full-time job (approx. 40 hours) while taking classes

(V) (N) Taken a remedial course

(V) (IN) Taken an ethnic studies course

(1) (IV) Taken a women's studies course

(1) (N) Attended a racial/cultural awareness workshop

(v) (iv) Had a roommate of different race/ethnicity

(v) (N) Played club, intramural, or recreational sports

(1) (N) Played intercollegiate athletics (e.g., NCAA or NAIA-sponsored)

(1) (N) Withdrawn from school temporarily

(V) (N) Taken an honors course

(1) (N) Transferred from a 2-year college

(1) (N) Transferred from a 4-year college

(D) (N) Taken courses for credit at another institution

(v) (N) Completed a culminating experience for your degree (e.g., capstone course/project, thesis, comp exam)

(1) (IN) Been a leader in an organization

(1) (N) Voted in the 2012 fall election

(1) (N) Joined a student-run political club

(1) (IN) Taken courses from more than one institution simultaneously

Taken a course exclusively online:

(1) (N) At this institution

(D) (N) At a different institution

Participated in:

(v) (N) An internship program

(V) (N) Study-abroad

(1) (II) Leadership training

(1) (II) Student government

(V) (N) Student clubs/groups

(v) (N) An ethnic/racial student organization

(V) (N) An undergraduate research program

(I) (N) An entrepreneurship program/club

For the next two questions, please use the codes on attached fold-out.

11. Mark your:

Undergraduate primary major

Undergraduate secondary major (omit if you do not have a secondary major) Graduate major (omit if you do not plan to go to graduate school)

12. Mark your probable career/ occupation.
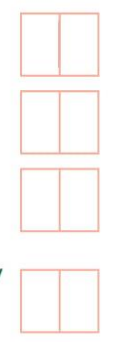
13. During the past year, how much time did you spend during a typical week doing the following activities? (Mark one in each row)

Studying/homework Attending classes/labs. Socializing with friends

Exercising/sports

Partying

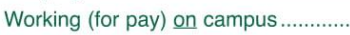

Working (for pay) off campus

Student clubs/groups..

Watching TV.

Housework/childcare .

Prayer/meditation

Career planning (job searches,

internships, etc.).............................

Online social networks (Facebook Twitter, etc.)...

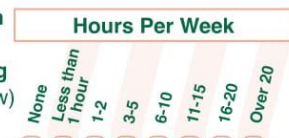
ร)

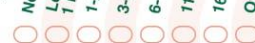
... 00000000 ... $\bigcirc 0000000$ ... 00000000 .. $\bigcirc \bigcirc \bigcirc \bigcirc \bigcirc \bigcirc \bigcirc \bigcirc$ .. 10000000 .... 00000000 .. 00000000 .... 00000000 ... 00000000 ... 00000000 ... 00000000 .... 00000000 .... 00000000

14. Think about your current abilities and tell us how strong or weak you believe you are in each of the following areas:

(Mark one for each item)

General knowledge

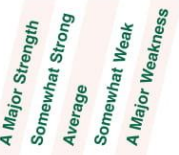
Knowledge of a particular field or discipline ......... (5) (4) (3) (2) (1) Knowledge of people from different races/cultures. (5) (4) (3) (2) (1) Understanding of the problems facing your community. (5) (4) (3) (2) (1) Understanding of national issues.

Understanding of global issues.

Critical thinking skills

Problem-solving skills.

Leadership abilities.

Ability to get along with people of different races/cultures.

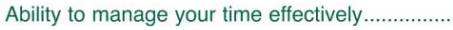
Foreign language ability ... Interpersonal skills

Preparedness for employment after college ..........

Preparedness for graduate or advanced education.

(5) (4) (3) (2) (1)

(5) (4) (3) (2) (1)

(5) (4) (3) (2) (1)

(5) (4) (3) (2) (1)

(5) (4) (3) (2) (1) (5) (4) (3) (2) (1) (5) (4) (3) (2) (1) (5) (4) (3) (2) (1) (5) (4) (3) (2) (1) (5) (4) (3) (2) (1) (5) (4) (3) (2) (1)

15. Please rate your satisfaction with your college in each area: (Mark one in each row)

General education or core curriculum

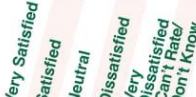

courses..

की

Science and mathematics courses ...

Humanities courses ................................... (6) (5) (4) (3) (2) (1)

Social science courses.............................. (6) (5) (4) (3) (2) (1)

Laboratory facilities and equipment .............. (6) (5) (4) (3) (2) (1)

Library facilities.......................................... (6) (5) (4) (3) (2) (1)

Computing assistance ................................... (6) (5) (4) (3) (2) (1)

Tutoring or other academic assistance ......... (6) (5) (4) (3) (2) (1)

Academic advising .................................... (6) (5) (4) (3) (2) (1)

Career counseling and advising................... (6) (5) (4) (3) (2) (1)

Student housing (e.g., res. halls) ................. (6) (5) (4) (3) (2) (1)

Financial aid package e.................................. (6) (5) (4) (3) (2) (1)

Job placement services for students ............. (6) (5) (4) (3) (2) (1)

Student health services .............................. (6) (5) (4) (3) (2) (1)

Student psychological services ................... (6) (5) (4) (3) (2) (1)
16. Please rate your satisfaction with your college in each area: (Mark one in each row)

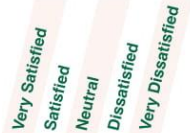

Courses in your major field......

(5) (4) (3) (2) (1)

Amount of contact with faculty

Class size...

Relevance of coursework to everyday life

Relevance of coursework to future career plans........ (5) (4) (3) (2) (1)

Overall quality of instruction ..................................... (5) (4) (3) (2) (1)

Overall sense of community among students ........... (5) (4) (3) (2) (1)

Availability of campus social activities....................... (5) (4) (3) (2) (1)

Respect for the expression of diverse beliefs ........... (5) (4) (3) (2) (1)

Ability to find a faculty or staff mentor...................... (5) (4) (3) (2) (1)

Racial/ethnic diversity of the student body................ (5) (4) (3) (2) (1)

Overall college experience ....................................... (5) (4) (3) (2) (1)

17. For the activities listed below, please indicate how often you engaged in each during the past year.

(Mark one in each row)

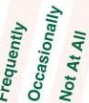

Smoked cigarettes

Felt depressed....... (F) (a) (18)

Felt overwhelmed by all I had to do ................................... (F) (O) (1)

Attended a religious service .............................................. (F) (O) (N)

Drank beer....................................................................... (F) (0) (1)

Drank wine or liquor .......................................................... (F) (1) (1)

Performed volunteer or community service work................. (F) (C) (1)

Discussed politics ............................................................ (F) (0) (1)

Sought personal counseling ............................................ (F) (0) (1)

Discussed religion ............................................................... (F) (O) (1)

Worked on a local, state, or national political campaign...... (F) (2) (1)

Contributed money to help support my family..................... (F) (0) (1)

Contributed money to a political campaign ......................... (F) (D) (14)

Applied concepts from courses to everyday life.................. (F) (D) (I)

Felt that faculty provided me with feedback that helped

me assess my progress in class....................................... (F) (D) (1)

Felt that my contributions were valued in class .................. (F) (C) (1)

Felt that faculty encouraged me to ask questions and

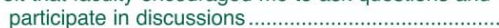

18. Rate yourself on each of the following traits as compared with the average person your age. We want the most accurate estimate of how you see yourself. (Mark one in each row)

Academic ability

Artistic ability ......

Computer skills

Cooperativeness..

Creativity...

Drive to achieve.

Emotional health

Leadership ability ...

Mathematical ability

Physical health ...

Public speaking ability...

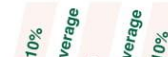

Risk-taking.

Self-confidence (intellectual)

Self-confidence (social)

Self-understanding

Spirituality...

Understanding of others

Writing ability.....

2 
19. Please indicate the extent to which you agree or disagree with the following statements: (Mark one in each row) I have felt discriminated against at this institution
because of my race/ethnicity, gender, sexual orientation, or religious affiliation .....

I see myself as part of the campus community Faculty showed concern about my progress ........ (4) (3) (2) (1) There is a lot of racial tension on this campus ..... (4) (3) (2) (1) Faculty empower me to learn here ...................... (4) (3) (2) (1) If asked, I would recommend this college to others. (4) (3) (2) (1) At least one staff member has taken an interest in my development............................................ (4) (3) (2) (1) I feel valued at this institution............................... (4) (3) (2) (1)

Faculty believe in my potential to succeed academically .................................................. (4) (3) (2) (1) Staff encouraged me to get involved in campus

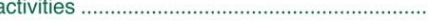

In class, I have heard faculty express stereotypes based on race/ethnicity, gender, sexual orientation, or religious affiliation .........

..... (4) (3) (2) (1)

Faculty encouraged me to meet with them

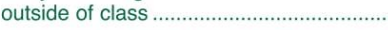

I am interested in seeking information about current social and political issues........

I feel a sense of belonging to this campus............ (4) (3) (2) (1) At least one faculty member has taken an interest in my development.............................. (4) (3) (2) (1) I feel I am a member of this college..................... (4) (3) (2) (1) I have effectively led a group to a common purpose .............................................................. (4) (3) (2) (1)

20. Rate yourself on each of the following traits as compared with the average person your age. We want the most accurate estimate of how you see yourself. (Mark one in each row)

Ability to see the world from someone else's perspective

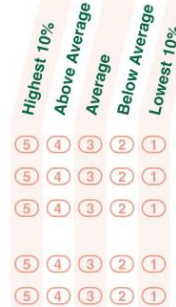

Tolerance of others with different beliefs......... (5) (4) (3) (2) (1) Openness to having my own views challenged. (5) (4) (3) (2) (1) Ability to discuss and negotiate controversial issues.

Ability to work cooperatively with diverse people. (5) (4) (3) (2) (1)

21. To what extent have you experienced the following with students from a racial/ethnic group other than your own? (Mark one in each row)

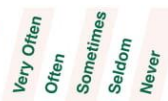

Dined or shared a meal

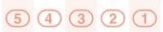

Had meaningful and honest discussions about race/ethnic relations outs

Had guarded, cautious interactions...................

(5) (4) (3) (1) Had tense, somewhat hostile interactions....... (5) (4) (3) (2) (1) Had intellectual discussions outside of class.. (5) (4) (3) (2) (1) Felt insulted or threatened because of your race/ethnicity.

Studied or prepared for class...............

Socialized or partied

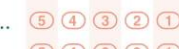

22. Think back over the past two weeks. How many times in the past two weeks, if any, have you had five or more alcoholic drinks in a row? (A drink can be a 12-ounce beer, a 4-ounce glass of wine, or a shot of liquor either straight or in a mixed drink.)
None
Twice
6-9 times
Once
3-5 times
10 or more times

23. Indicate the importance to you personally of each of the following: (Mark one in each row)

Becoming accomplished in one of the performing arts (acting, dancing, etc.).......

Becoming an authority in my field

Obtaining recognition from my colleagues for

contributions to my special field.

Influencing social values ....................................... (E) (v) (S) (N)

Raising a family .......................................... (E) (v) (S) (N)

Being very well off financially ................................ (E) (v) (S) (N)

Helping others who are in difficulty .......................... (E) (v) (S) (N)

Making a theoretical contribution to science .............. (E) (V) (S) (N)

Writing original works (poems, novels, etc.).............. (E) (v) (S) (N)

Creating artistic work (paintings, sculpture, etc.) ....... (E) (V) (S) (N)

Becoming successful in a business of my own.......... (E) (v) (S) (N)

Becoming involved in programs to clean up the

environment ...................................................... (E) (v) (S) (N)

Developing a meaningful philosophy of life................ (E) (v) (5) (1)

Participating in a community action program ............. (E) (V) (S) (N)

Helping to promote racial understanding ................... (E) (v) (S) (N)

Keeping up to date with political affairs..................... (E) (V) (S) (N)

Becoming a community leader................................. (E) (v) (S) (N)

Integrating spirituality into my life .............................. (E) (v) (S) (N)

Improving my understanding of other countries

and cultures......

24. How often have professors at your college provided you with: (Mark one in each row)

Encouragement to pursue graduate/professional study............ (F) (C) (Ni)

An opportunity to work on a research project ........................... (F) (D) (ii)

Advice and guidance about your educational program.............. (F) (1) (11)

Emotional support and encouragement .................................. (F) (C) (II)

A letter of recommendation .................................................... (F) (D) (ii)

Honest feedback about your skills and abilities ........................ (F) (O) (1)

Help to improve your study skills ............................................ (F) (C) (1)

Feedback on your academic work (outside of grades) ............. (F) (0) (ii)

Intellectual challenge and stimulation ..................................... (F) (O) (ii)

An opportunity to discuss coursework outside of class ............ (F) (D) (1)

Help in achieving your professional goals.............................. (F) (O) (1)

An opportunity to apply classroom learning to "real-life" issues . (F) (D) (II)

An opportunity to publish........................................................ (E) (C) (I)

25. Please indicate your agreement with each of the following statements. (Mark one in each row)

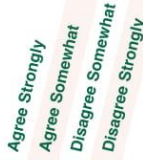

Same-sex couples should have the right to legal marital status..... (4) (3) (2) (1) Racial discrimination is no longer a major problem in America...... (4) (3) (2) (1) Abortion should be legal............................................................ (4) (3) (2) (1) Realistically, an individual can do little to bring about changes in our society ............................................................................... (4) (3) (2) (1) Colleges should prohibit racist/sexist speech on campus............... (4) (3) (2) (1) Dissent is a critical component of the political process.................. (4) (3) (2) (1) Colleges have the right to ban extreme speakers from campus .... (4) (3) (2) (1) Students from disadvantaged social backgrounds should be given preferential treatment in college admissions...................... (4) (3) (2) (1) Only volunteers should serve in the armed forces........................ (4) (3) (2) (1) 
26. If you borrowed money to help pay for college expenses, estimate how much you will owe as of June 30,2013 :

27. How much of the past year's educational expenses (room, board, tuition, and fees) were covered from each of the following sources? (Mark one answer for each possible source)

Family resources (parents, relatives, spouse, etc.)..

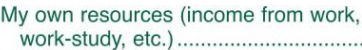
Aid which need not be repaid (grants, scholarships, military, etc.).

Aid which must be repaid (loans, etc.).... Other sources.

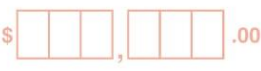
.00 (5) (5) (3) (2) (1)

28. When thinking about your career path after college, how important are the following considerations: (Mark one in each row)

Working for social change......

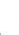

(6) (5) (4) (3) (2) (1)

High income potential...

Social recognition or status ....

Stable, secure future ..................................... (E) (v) (S) (iv

Creativity and initiative ................. (E) (v) (S) (N)

Expression of personal values ...................... (E) (1) (S) (1)

Availability of jobs....................................... (E) (IV) (S) (II)

Leadership potential ..................................... (E) (v) (S) (1)

Work/life balance ........................................... (E) (v) (S) (N)

Ability to pay off debt................................... (E) (v) (S) (1)

Opportunity for innovation............................. (E) (v) (S) (1)

29. What do you plan to be doing in fall 2013? (Mark all that apply)

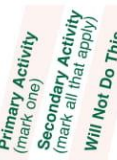

Working full-time

Working part-time Attending graduate/professional school part-time. (P) (S) (W) Completing additional undergraduate coursework/Post-baccalaureate program ........ (P) (S) (II) Participating in an organization like the Peace

Corps, AmeriCorps/VISTA, or Teach for America. (P) (S) (WI) Serving in the Armed Forces.............................. (P) (S) (vi)

Traveling ....................................................... (P) (S) (III) Volunteer work.................................................... (P) (S) (W)

Staying at home to be with or start a family....... (P) (S) (II)

No current plans.

(P) (S) (VI)

30. If you are planning on being employed after graduation, which best describes the current state of your employment plans? (Mark one response only)

Not actively looking for a position

Looking, but no offers yet

Received an offer for a position, but declined

Currently considering an offer

Accepted an offer of employment

Not planning on employment this fall

\footnotetext{
(c) Prepared by the Higher Education Research Institute,
University of California, Los Angeles, California, $90095-152$
}

31. If you are planning to attend graduate or professional school, which of the following best estimates the current state of your educational plans? (Mark one response only)

Accepted and will be attending in the fall

Accepted and deferred admission until a later date

Placed on waiting list, no acceptances

Still awaiting responses, no acceptances

Will be applying this coming fall

Not applying this fall, but might apply at a future date

No plans to apply to school now or in the future

32. Please indicate the highest degree you (A) will have earned as of June 2013 and (B) plan to complete eventually at any institution. (Mark one in each column)

None...

Vocational certificate

Associate (A.A. or equiv.) ..

Bachelor's (B.A., B.S., etc.)

Master's (M.A., M.S., etc.)

Ph.D. or Ed.D.

M.D., D.O., D.D.S., or D.V.M

LL.B. or J.D. (Law)

B.D. or M.DIV. (Divinity)

Other.

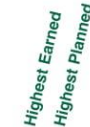

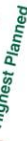

3. If you could make your college choice over, would you still choose to enroll at your current college?
Definitely yes
Probably no
Definitely no

Probably yes

34. What is the average grade you received during your college career, both overall and $x_{t}^{+}$ in your major? (Mark one circle in each row) के क की का की 0 Overall GPA................................................ $\bigcirc 0000000$ Primary Major GPA.

35. Your current religious preference: (Mark one) Baptist................. $\bigcirc$ LDS (Mormon).. $\bigcirc$ Seventh Day Adventist. $\bigcirc$ Buddhist............... $\bigcirc$ Lutheran .......... $\bigcirc$ United Church of Christ/ Church of Christ ... $\bigcirc$ Methodist......... $\bigcirc$ Congregational........ $\bigcirc$ Eastern Orthodox. $\bigcirc$ Muslim ............. Other Christian ........... $\bigcirc$ Episcopalian ......... $\bigcirc$ Presbyterian .... $\bigcirc$ Other Religion ............. $\odot$ Hindu ................... $\bigcirc$ Quaker............. $\bigcirc$ None ............................ $\bigcirc$ Jewish................. $\bigcirc$ Roman Catholic.

36. Please indicate your racial/ethnic background. (Mark all that apply)
White/Caucasian
African American/Black
Mexican American/Chicano
American Indian/Alaska Native
Puerto Rican
Asian American/Asian
Other Latino
Native Hawaiian/Pacific Islander

ADDITIONAL QUESTIONS: If you received an additional page of questions, please mark your answers below:
37. (A) (B) (C) (D) (E)
44. (A) (B) (C) (D) (E)
51. (A) (B) (C) (D) (E)
38. (A) (B) (C) (D) E
45. (A) (B) (C) (D) (E)
39. (A) (B) (C) (D) (E)
46. (A) (B) (C) (D) (E)
40. (A) (B) (C) (D) (E)
47. (A) (B) (C) (D) (E)
1. (A) (B) (C) (D) E)
48. (A) (B) (C) (D) E
42. (A) (B) (C) (D) (E)
49. (A) (B) (C) (D) (E)
52. (A) (B) (C) (D) E
53. (A) (B) (C) (D) E
54. (A) (B) (C) (D) (E)
55. (A) (B) (C) (D) (E)
56. (A) (B) (C) (D) (E)

43. (A) (B) (C) (D) (E)

50. (A) (B) (C) (D) (E)
THANK YOU! 
COLLEGE SENIOR SURVEY STUDENT INFORMATION SHEET

PURPOSE OF THE STUDY

You are asked to complete this survey as part of a national study of higher education conducted by the Higher Education Research Institute (HERI) at the University of California, Los Angeles. One major goal of this research is to determine what happens to students when they attend college. The data gathered are used in studies designed to better understand student learning and development and to help improve the quality of college education.

\section{PROCEDURES}

To participate in this study, please complete the attached survey and return it to the designated person at your campus. Most respondents complete this questionnaire in about 25 minutes, although individual progress will vary by how quickly you move through the questions.

You may decide not to complete the survey for any reason at any time without consequence of any kind. The Higher Education Research Institute does not offer payment for participation. Your participation and return of the enclosed questionnaire indicate your consent to participate in the study.

POTENTIAL BENEFITS TO SUBJECTS AND/OR SOCIETY You may have the opportunity to reflect on your prior academic experiences and your expectations for college as you complete the survey, which may enhance self-understanding. Results of your participation also will be directly beneficial to your college or university, and may benefit future generations of college students as well.

POTENTIAL RISKS AND DISCOMFORTS

There could be survey items that you are uncomfortable answering or to which you would simply prefer not to respond. Your participation in this study is strictly voluntary, and you will be under no obligation whatsoever to answer any questions that you are not inclined to answer. You may choose not to answer any specific questions you do not want to answer and still remain in the study.

CONFIDENTIALITY

Please note that your responses will be used for research purposes only and will be strictly confidential. Any information that is

obtained in connection with this study and that can be identified with you will remain confidential. Your identified responses will be returned to your institution for institutional assessment purposes. Before receiving any responses, your school is required to certify in advance that the data will only be used for research purposes and will not be used to investigate specific individuals.

IDENTIFICATION OF INVESTIGATORS

If you have any questions or concerns about the research, please contact the Managing Director of HERI, John H. Pryor, at this address:

Higher Education Research Institute

UCLA Graduate School of Education and Information Studies Box 951521

Los Angeles, CA 90095-1521

Email: heri@ucla.edu

Phone: 310-825-1925

RIGHTS OF RESEARCH SUBJECTS

You may withdraw your consent at any time and discontinue participation without penalty. You are not waiving any legal claims. rights or remedies because of your participation in this research study. If you have questions regarding your rights as a research subject, contact the UCLA Office for Protection of Research Subjects, 11000 Kinross Avenue, Suite 102, Box 951694, Los Angeles, CA 90095-1694, (310) 825-7122. 
APPENDIX B: THE FRESHMAN SURVEY

$\top$

2009 CIRP FRESHMAN SURVEY

CIRP

PLEASE PRINT IN ALL CAPS YOUR NAME AND PERMANENT/HOME ADDRESS (one letter or number per box).

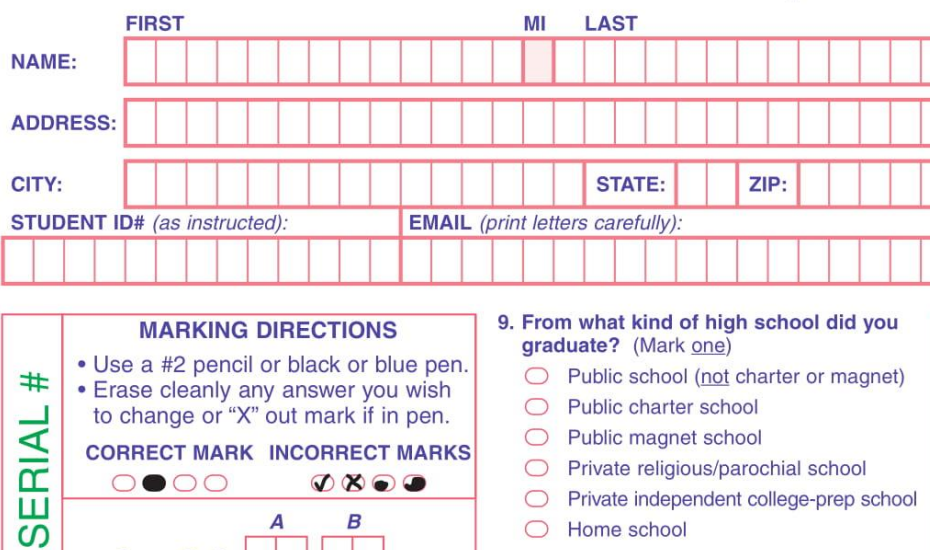

Group Code

\begin{tabular}{|l|l|}
$\square \square$ \\
\hline
\end{tabular}

1. Your sex: $\bigcirc$ Male $\bigcirc$ Female

2. How old will you be on December 31 of this year? (Mark one)

16 or younger. $\square$

18

21-24

18.

(

20.

25-29

30-39

40-54 .........

3. Is English your native language? $\bigcirc$ Yes $\bigcirc$ No

4. In what year did you graduate from high school? (Mark one)

2009.......... $\bigcirc$ Did not graduate but

2008 _.... $\bigcirc$ passed G.E.D. test .

2007.......... $\bigcirc$ Never completed

2006 or earlier $\bigcirc$ high school..

5. Are you enrolled (or enrolling) as a: (Mark one) Full-time student?... Part-time student? ..... $\bigcirc$

6. How many miles is this college from your permanent home? (Mark one)

5 or less $\bigcirc \quad 11-50 \bigcirc \quad 101-500 \bigcirc$

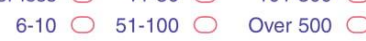

7. What was your average grade in high school? (Mark one)

A or $A+\bigcirc \quad B \quad C \bigcirc$

A- $\bigcirc \quad B-\bigcirc$

$\mathrm{B}+\mathrm{C}+\mathrm{O}$

8. What were your scores on the SAT and/or ACT?

SAT VERBAL

SAT MATH

SAT WRITING

D

ACT Composite

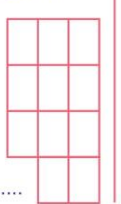

10. Prior to this term, have you ever taken courses for credit at this institution?

$\bigcirc$ Yes $\bigcirc$ No

11. Since leaving high school, have you eve taken courses, whether for credit or not for credit, at any other institution (university, 4- or 2-year college, technical, vocational, or business school)?
$\bigcirc$ Yes
No

12. Where do you plan to live during the fall term? (Mark one)

With my family or other relatives ............ Other private home, apartment, or room. College residence hall.....

Fraternity or sorority house

Other campus student housing ......

Other.

13. To how many colleges other than this one did you apply for admission this year?

None $1 \bigcirc 4 \bigcirc \quad 7-10 \bigcirc$

$\bigcirc \quad 2 \bigcirc 5 \bigcirc 11$ or more $\bigcirc$

$$
3 \bigcirc 6 \bigcirc
$$

14. Were you accepted by your first choice college? $\bigcirc$ Yes $\bigcirc$ No

15. Is this college your: (Mark one) First choice? .......... $\bigcirc$ Less than third Second choice?..... $\bigcirc$ choice?......... $\bigcirc$ Third choice? ..........

16. Citizenship status:

$\bigcirc$ U.S. citizen

Permanent resident (green card)

$\bigcirc$ Neither

17. Are you a veteran? (Mark one)

$$
\bigcirc \text { Yes } \bigcirc \text { No }
$$

18. Are your parents: (Mark one) Both alive and living with each other?... Both alive, divorced or living apart? ...... $\bigcirc$ One or both deceased?........................

19. Have you had, or do you feel you will need, any special tutoring or remedial work in any of the following subjects?

(Mark all that apply)

English.

Reading ................................................... $\bigcirc \bigcirc$

Mathematics .

Social Studies.......................................... $\bigcirc$

Science..................................................... $\bigcirc$

Foreign Language ................................... $\bigcirc$

Writing ................................................... $\bigcirc$

20. How many Advanced Placement courses or exams did you take in high school? (Mark one in each row)

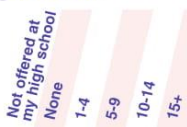

AP Courses

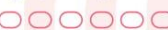

AP Exams........................ $\bigcirc \bigcirc \bigcirc \bigcirc \bigcirc$

21. What is the highest academic degree that you intend to obtain? (Mark one in each column)

None Vocational certificate .......................... $\bigcirc \ldots$ Associate (A.A. or equivalent) .......... $\bigcirc \ldots \bigcirc$ Bachelor's degree (B.A., B.S., etc.).. $\bigcirc \ldots \bigcirc$ Master's degree (M.A., M.S., etc.)... $\bigcirc \ldots \bigcirc$ Ph.D. or Ed.D................................. $\bigcirc \ldots$ M.D., D.O., D.D.S., or D.V.M.............. $\bigcirc$... $\bigcirc$ J.D. (Law) ........................................ $\bigcirc$... B.D. or M.DIV. (Divinity) ..................... $\bigcirc$... $\bigcirc$ Other............................................. $\bigcirc \ldots$

22. How would you describe the racial composition of the high school you last attended and the neighbor- क्षे क्ष hood where you grew up?
(Mark one in each row) High school I last attended.... $\bigcirc 0 \bigcirc \bigcirc 0$ Neighborhood where I grew up. 00000 
23. How much of your first year's educational expenses (room, board, tuition, and fees) do you expect to cover from each of the sources listed below?

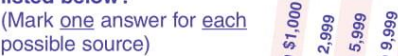

Family resources (parents,
relatives, spouse, etc.) ........ 000000

My own resources (savings

from work, work-study,

other income) ....................... $\bigcirc \bigcirc \bigcirc \bigcirc \bigcirc$

Aid which need not be repaid

(grants, scholarships,

military funding, etc.) ........... $\bigcirc \bigcirc \bigcirc \bigcirc \bigcirc$

Aid which must be repaid

(loans, etc.).......................... $\bigcirc \bigcirc \bigcirc \bigcirc \bigcirc$

Other than above.................... $\bigcirc \bigcirc \bigcirc \bigcirc \bigcirc \bigcirc$

24. What is your best estimate of your parents' tota income last year? Consider income from all sources before taxes. (Mark one)

$\bigcirc$ Less than $\$ 10,000 \bigcirc \$ 50,000-59,999$

$\$ 10,000-14,999$

\$15,000-19,999 $\bigcirc$ \$75,000-99,999

\$20,000-24,999 $\$ 100,000-149,999$

\$25,000-29,999 $\$ \$ 150,000-199,999$

\$ $\$ 30,000-39,999 \quad \bigcirc 200,000-249,999$

$\bigcirc 40,000-49,999 \bigcirc \$ 250,000$ or more

25. Do you have any concern about your ability to finance your college education? (Mark one)

None (I am confident that I will have sufficient funds) .......... Some (but I probably will have enough funds) .... Major (not sure I will have enough funds to complete college)..

26. Current religious preference: (Mark one in each column)

Baptist...

Buddhist

Church of Christ.

(V) (F) (II)

Eastern Orthodox

(V) (F) (III)

Episcopalian .....

(V) (F) (M)

(V) (F) (M)

Hindu .................................................... (1) (F) (M)

Jewish................................................... (v) (F) (MiM)

LDS (Mormon) ........................................ (1) (F) (11)

Lutheran .................................................. (1) (F) (M)

Methodist ............................................ (1) (F) (III)

Muslim ................................................ (1) (E) (MI)

Presbyterian .......................................... (I) (F) (II)

Quaker.................................................... (1) (F) (M)

Roman Catholic ....................................... (1) (F) (M)

Seventh Day Adventist .......................... (V) (F) (Mi)

United Church of Christ/Congregational . (V) (F) (MII)

Other Christian ................................................ (8) (F) (1)

Other Religion ................................................ (1) (F) (III)

None ……................................................... (8) (F) (Mi)
27. For the activities below, indicate which ones you did during the past year. If you engaged in an activity frequently, mark (F). If you engaged in an activity one or more times, but not frequently, mark (a) (Occasionally). Mark (N) (Not at all)

if you have not performed the activity during the past year.

(Mark one for each item)

Attended a religious service

Was bored in class .................... (F) (0) (I)

Participated in political

demonstrations ......................... (F) (1) (1)

Tutored another student $\quad$ (F) (0) (N)

Studied with other students....... (F) (D) (1)

Was a guest in a teacher's home.... (F) (0) (I)

Smoked cigarettes...................... (F) () (1)

Drank beer................................ (F) (D) (I)

Drank wine or liquor

Felt overwhelmed by all I had to do... (F) (1) (I)

Felt depressed.......................... (F) (D) (1)

Performed volunteer work .......... (F) () () (I)

Played a musical instrument ...... (F) (0) (N)

Asked a teacher for advice

after class.............................. (F) (O) (I)

Voted in a student election......... (F) (2) (N)

Socialized with someone of

another racial/ethnic group....... (F) (D) (I)

Came late to class..................... (F) (1) (17)

Used the Internet:

For research or homework ....... (F) (2) (II)

To read news sites.................... (F) (0) (N)

To read blogs $\quad$ (F) (1) (II)

To blog................................... (F) (0) (N)

Performed community service

as a part of a class................... (F) (1) (N)

Discussed religion ....................... (F) (D) (I)

Discussed politics.

Skipped school/class................... (F) (0) (N)

28. Rate yourself on each of the following traits as compared with the average person your age. We

want the most accurate estimate of

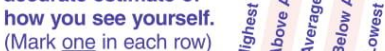

Academic ability .....

Artistic ability......

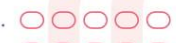

00000

Computer skills........... $\bigcirc \bigcirc \bigcirc \bigcirc$

Cooperativeness.......... 00000

Creativity ...................... 00000

Drive to achieve .......... 00000

Emotional health......... $\bigcirc \bigcirc \bigcirc \bigcirc \bigcirc$

Leadership ability ....... 00000

Mathematical ability.... $\bigcirc 0000$

Physical health ............ 00000

Popularity..................... $\bigcirc \bigcirc \bigcirc \bigcirc \bigcirc$

Public speaking ability. 00000

Self-confidence

(intellectual)............... $\bigcirc \bigcirc \bigcirc \bigcirc 0$

Self-confidence (social).. $\bigcirc 0000$

Self-understanding ..... 00000

Spirituality ................... $00 \bigcirc \bigcirc \bigcirc$

Understanding of

others ................

Writing ability............... $00 \bigcirc \bigcirc$
29. Rate yourself on each of the following traits as compared with the average person your age. We want the most accurate estimate of how you see

yourself.

(Mark one for each item)

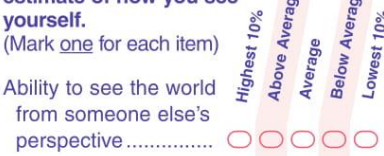

Tolerance of others

with different beliefs. 00000

Openness to having

my own views

challenged................. $\bigcirc \bigcirc \bigcirc \bigcirc$

Ability to discuss and

negotiate controversial

issues

Ability to work

cooperatively with

diverse people.

30. What is the highest level of formal education obtained by your parents? (Mark one in each column)

Grammar school or less....... $\bigcirc \ldots \bigcirc$

Some high school................... $\bigcirc$...

High school graduate ........... $\bigcirc \ldots \bigcirc$

Postsecondary school

other than college................ $\bigcirc \ldots$

Some college.......................... $\bigcirc \ldots \bigcirc$

College degree ...................... $\bigcirc \ldots \bigcirc$

Some graduate school ......... $\bigcirc$... $\bigcirc$

Graduate degree .................... $\bigcirc$...

31. How often in the past year did you?

(Mark one for each item)

Ask questions in class ........... (F) (1) (N)

Support your opinions with

a logical argument............... (F) (1) (N)

Seek solutions to problems

and explain them to others... (F) (1) (N)

Revise your papers to

improve your writing ............ (F) (0) (N)

Evaluate the quality or

reliability of information

you received.

(F) ()

Take a risk because you fee

you have more to gain......... (F) (D) (N)

Seek alternative solutions

to a problem ....................... (F) (0) (N)

Look up scientific research

articles and resources......... (F) (0) (N)

Explore topics on your own,

even though it was not

required for a class............. (F) (0) (N)

Accept mistakes as part of

the learning process........... (F) (0) (1)

Seek feedback on your

academic work .................... (F) (O) (N)

Take notes during class......... (F) (0) (1)

Work with other students

on class assignments......... (F) (0) (N) 


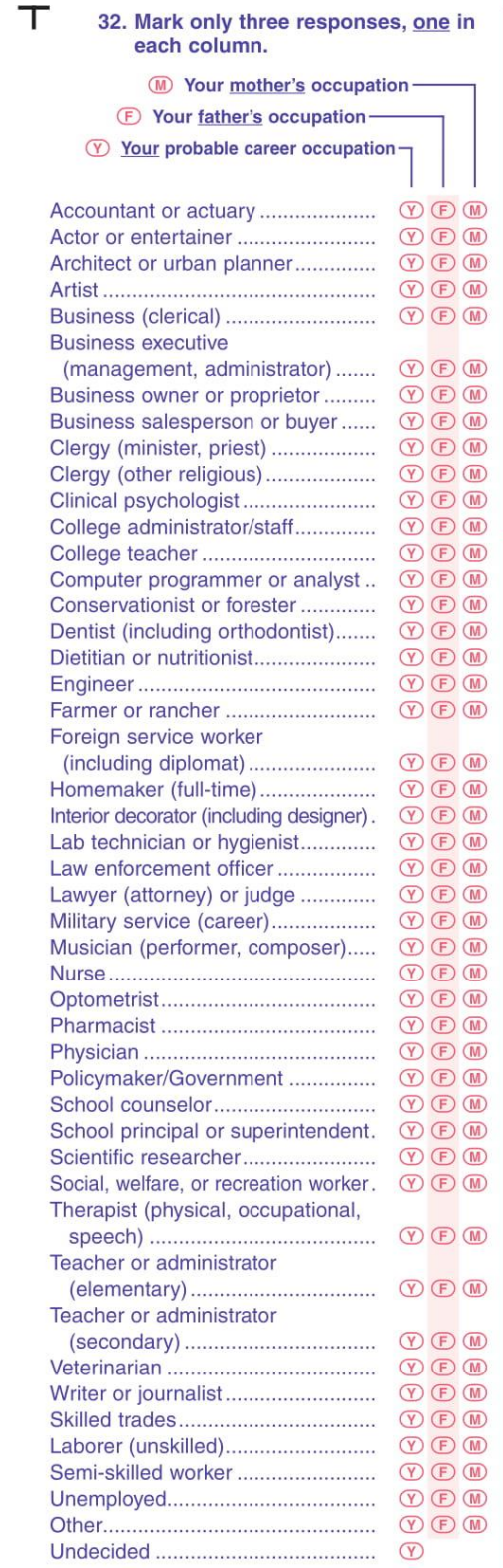

33. Are you: (Mark all that apply)

White/Caucasian .......................... African American/Black ...................

American Indian/Alaska Native .......

Asian American/Asian .......................

Native Hawaiian/Pacific Islander ..... $\bigcirc$

Mexican American/Chicano .............. $\bigcirc$

Puerto Rican...................................... $\bigcirc$

Other Latino.........................................

Other................................................

34. Mark one in each row:

(1) Disagree Strongly

(

\section{There}

Marijuana should be legalized ....................................................... (4) (3) (2) (1)

Racial discrimination is no longer a major problem in America................................... (4) (3) (2) (1)

Realistically, an individual can do little to bring about changes in our society.......... (4) (3) (2) (1)

Same-sex couples should have the right to legal marital status............................ (4) (3) (2) (1)

Only volunteers should serve in the armed forces................................................. (4) (3) (2) (1)

Dissent is a critical component of the political process.......................................... (4) (3) (2) (1)

Colleges have the right to ban extreme speakers from campus............................. (4) (3) (2) (1)

Students from disadvantaged social backgrounds should be given preferential

treatment in college admissions..................................................................... (4) (3) (2) (1)

Colleges should prohibit racist/sexist speech on campus...................................... (4) (3) (2) (1)

35. How would you characterize your

political views? (Mark one)

$\bigcirc$ Far left

$\bigcirc$ Liberal

Middle-of-the-road

Conservative

Far right

36. In deciding to go to college, how important to you was each of the following reasons?

(Mark one answer for each possible reason)

My parents wanted me to go..........

To be able to get a better job .......... (v) (S) (N)

To gain a general education

and appreciation of ideas............. (v) (S) (N)

To make me a more cultured

person .........

To be able to make more money..... (v) (S) (N)

To learn more about things that

interest me

(1) (S) (N)

37. During your last year in high school, how much time did you spend during a typical week doing the following activities?

䒺

Hours per week: $\quad$ र Studying/homework.... $\bigcirc \bigcirc \bigcirc \bigcirc \bigcirc \bigcirc \bigcirc \bigcirc$ Socializing with friends. 00000000 Talking with teachers

outside of class ........ (1) (for pay) ......... 00000000 Volunteer work............. 00000000 Student clubs/groups.. $\bigcirc \bigcirc \bigcirc \bigcirc \bigcirc \bigcirc \bigcirc \bigcirc$ Watching TV ............... 00000000 Household/childcare

duties....................... $\bigcirc \bigcirc \bigcirc \bigcirc \bigcirc \bigcirc \bigcirc$ Reading for pleasure.. $\bigcirc \bigcirc \bigcirc \bigcirc \bigcirc \bigcirc \bigcirc \bigcirc$ Playing video/

computer games..... 00000000

Online social networks (MySpace, Facebook, etc). 00000000
38. Below are some reasons that might have influenced your decision to attend this particular college. How important was each reason in your decision to come here? (Mark one answer for each possible reason)

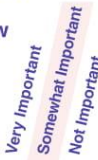

My parents wanted me to come here... (v) (S) (I) My relatives wanted me to come here... (v) (S) (I) My teacher advised me ...................... (v) (5) (1)

This college has a very good academic reputation......................... (v) (5) (1) This college has a good reputation for its social activities ......................... (v) (5) (1) I was offered financial assistance........ (v) (S) (N) The cost of attending this college ....... (v) (5) (I) High school counselor advised me ..... (V) (S) (I) Private college counselor advised me..... (v) (S) (I) I wanted to live near home .................. (v) (5) (1) Not offered aid by first choice.............. (v) (5) (II) Could not afford first choice ................ (v) (5) (1) This college's graduates gain admission to top graduate/ professional schools........................ (v) (S) (I) This college's graduates get good jobs. (V) (S) (N) I was attracted by the religious affiliation/orientation of the college.... (v) (S) (N) I wanted to go to a school about the size of this college ............................. (v) (S) (N) Rankings in national magazines ......... (v) (S) (I) Information from a website .................. (v) (S) (I)

I was admitted through an Early

Action or Early Decision program ..... (v) (S) (N)

The athletic department recruited me. (v) (5) (1) A visit to the campus ........................... (v) (5) (N) Ability to take online courses.............. (v) (S) (I) 
39. Below is a list of different undergraduate major fields grouped into general categories. Mark only one oval to indicate your probable field of study.

\section{ARTS AND HUMANITIES}

Art, fine and applied..........

English (language and

literature) .......................... (2)

History ……......................... (3)

Journalism ............................ (4)

Language and Literature

(except English) ................. (5)

Music ....................................... (6)

Philosophy ….......................... (7)

Speech .........

Theater or Drama ...............

Theology or Religion ............. (10

Other Arts and Humanities... (11

BIOLOGICAL SCIENCE

Biology (general)

Biochemistry or

Biophysics ......................... (13

Botany ................................ (14

Environmental Science......... (15)

Marine (Life) Science ........... (16)

Microbiology or

Bacteriology ...................... (17)

Zoology.................................... (18

Other Biological Science ....... (19

BUSINESS

Accounting ......................... (20)

Business Admin. (general) ... (211

Finance.................................. (22)

International Business .......... (23)

Marketing............................... (24)

Management.......................... (25)

Secretarial Studies .................. (26)

Other Business........................ (27)

EDUCATION

Business Education ............... (28)

Elementary Education .......... (29)

Music or Art Education ......... (30

Physical Education or

Recreation ......................... (31)

Secondary Education ............. (32)

Special Education ................... (33)

Other Education .................... (34)

ENGINEERING

Aeronautical or

Astronautical Eng............... (35)

Civil Engineering .................... (36)

Chemical Engineering ............. (37)

Computer Engineering ........... (38

Electrical or Electronic

Engineering ...................... (39)

Industrial Engineering........... (40

Mechanical Engineering....... (41

Other Engineering ................ (42
PHYSICAL SCIENCE

Astronomy ………....

Atmospheric Science

(incl. Meteorology).............. (4)

Chemistry .............................. (45)

Earth Science...................

Marine Science (incl.

Oceanography)...

Mathematics.....

(4........................

PROFESSIONAL

Architecture or Urban

Planning......

Family \& Consumer Sciences.

Health Technology (medi-

cal, dental, laboratory) ...... (53)

Library or Archival Science ..

Medicine, Dentistry,

Veterinary Medicine............ (55)

Nursing ..................................

Pharmacy ................................ (57)

Therapy (occupational,

physical, speech) ............... (58

Other Professional................

SOCIAL SCIENCE

Anthropology ....

Economics...

Ethnic Studies ........................ (62

Geography

Political Science (gov't

international relations)

Psychology.....

Public Policy.

Social Work

Sociology.

Women's Studies............................

Other Social Sciences............

TECHNICAL

Building Trades

Data Processing or

Computer Programming....

Drafting or Design ...

Electronics.

Mechanics

Other Technical

OTHER FIELDS

Agriculture ....

Communications...

Computer Science....

Forestry

Kinesiology

Law Enforcement....

Military Science

Other Field

Undecided

40.Please indicate the importance to you personally of each of the following: (Mark one for each item)

(N) Not Important (5) Somewhat Important

Becoming accomplished in one of (E) Essential

the performing arts (acting, dancing, etc.) ....................... (E) (V) (S) (N) Becoming an authority in my field ................................... (E) (v) (S) (N) Obtaining recognition from my colleagues for contributions to my special field ........................................ (E) (v) (S) (1) Influencing the political structure...................................... (E) (v) (S) (N) Influencing social values .................................................. (E) (v) (S) (1) Raising a family ........................................................... (E) (V) (S) (N) Being very well off financially ........................................... (E) (v) (S) (N) Helping others who are in difficulty .................................. (E) (v) (S) (II) Making a theoretical contribution to science ...................... (E) (v) (S) (N) Writing original works (poems, novels, short stories, etc.)... (E) (V) (S) (N) Creating artistic works (painting, sculpture, decorating, etc.) . (E) (V) (S) (N) Becoming successful in a business of my own .................. (E) (v) (S) (III) Becoming involved in programs to clean up the environment. (E) (V) (S) (N) Developing a meaningful philosophy of life ...................... (E) (V) (S) (II) Participating in a community action program ...................... (E) (V) (S) (N) Helping to promote racial understanding ........................... (E) (v) (S) (N) Keeping up to date with political affairs............................ (E) (V) (S) (N) Becoming a community leader .......................................... (E) (v) (S) (1) Improving my understanding of other countries and cultures. (E) (v) (S) (II) Adopting "green" practices to protect the environment ....... (E) (v) (S) (N)

41. What is your best guess as to the chances that you will: (Mark one for each item)

Change major field? .......

(N) No Chance

(L) Very Little Chance

Change career choice? ........................................................... (v) (S) (D) (N)

Participate in student government?.......... (v) (S)

Get a job to help pay for college expenses?

Work full-time while attending college? ................................... (v) (S) (L) (N)

Join a social fraternity or sorority? ................................................ (v) (S) (b) (d)

Play club, intramural, or recreational sports? .......................... (v) (S) (L) (I)

Play intercollegiate athletics (e.g., NCAA or NAIA-sponsored)?. (v) (S) (L) (N)

Make at least a "B" average? .............................................. (v) (S) (L) (N)

Need extra time to complete your degree requirements?.......... (1) (S) (1) (I)

Participate in student protests or demonstrations? ..................... (v) (S) (D) (1)

Transfer to another college before graduating?........................ (v) (S) (L) (N)

Be satisfied with your college? ............................................... (v) (S) (L) (1)

Participate in volunteer or community service work?................ (v) (S) (L) (N)

Seek personal counseling? ......................................................... (v) (5) (D) (d)

Communicate regularly with your professors? ............................ (v) (S) (D) (N)

Socialize with someone of another racial/ethnic group?........... (v) (S) (L) (N)

Participate in student clubs/groups?

Participate in a study abroad program? ...................................... (v) (S) (L) (1)

Have a roommate of a different race/ethnicity? ......................... (v) (S) (D) (I)

Discuss course content with students outside of class?............ (v) (S) (D) (N)

Work on a professor's research project?

42. Do you give the Higher Education Research Institute (HERI) permission to include your ID number should your college request the data for additional research analyses? HERI maintains strict standards of confidentiality and research analyses? HERI maintains strict standards of confide
would require your college to sign a pledge of confidentiality.

$\bigcirc$ Yes $\bigcirc$ No 
CURRICULUM VITA

Elizabeth K. Liebschutz-Roettger

1015 Golden Maple Cove Louisville, KY 40223

502-852-2856 (office)* 773-531-7907 (mobile)* eklieb01@ louisville.edu

\section{EDUCATION}

Ph.D., Counseling \& Personnel Services December 2019

\section{University of Louisville, Louisville, KY}

Provost Staff Leadership Academy, inaugural class (2013-2014)

Selected as one of 23 participants from a University-wide applicant pool.

Entrepreneurship Academy, inaugural class (Fall 2014)

Selected as one of 20 graduate student participants

Delphi U Teaching and Learning Academy for Online Course Design (2019)

M.S., Social and Philosophical Studies in Education May 2012

University of Kentucky, Lexington, KY

M.A., Human Services and Counseling August 2004

DePaul University, Chicago, IL

B.A., French May 2000

Lake Forest College, Lake Forest, IL

INTERNATIONAL EXPERIENCE

Clemson University Comparative Higher Education in Scotland, Scotland

July 2007

College International de Cannes, Cannes, France

January 1999 -June1999

Intermediate to Advanced Knowledge of French Language, written and spoken.

Beginner Knowledge of Spanish Language.

Traveled professionally and personally to 20 countries and 8 islands. 


\section{PROFESSIONAL EXPERIENCE}

\section{THE UNIVERSITY OF LOUISVILLE February 2009-Present}

Public, four-year, research institution in Louisville, KY; 18,454 FTE (15,772

undergraduate, 5714 graduate)

Director of Undergraduate International Programs, College of Business (January 2014-Present)

In addition to all duties of the International Coordinator role, provide strategic direction for international exchange, dual-degree programs, and education abroad opportunities for Undergraduate students in the College of Business. Supervise Masters level employees as well as graduate and undergraduate interns.

- Recruit and place College of Business students in international academic and internship placements.

- Assist in developing strategic plan for University-wide international initiatives.

- Vetted and recommended, in conjunction with the University's International Center, an emergency medical and evacuation insurance plan provider for international travel for faculty, staff, students, and guests.

- Research and implement policies for Clery and Title IX as they pertain to international programs.

- Advocate for University policies and plans to benefit students, especially at the undergraduate level (financial aid, academic course transfer, etc.).

- Recruit UG students for participate in UofL's Global MBA program.

- Assist students in seeking post-graduate international opportunities.

- Assess College of Business study abroad partnerships and student experiences.

- Co-write University international policies and goals for University's $21^{\text {st }}$ Century Initiatives.

- Increased College of Business exchange partners by $25 \%$ with focus on AACSB and EQUIS accredited schools.

- Provide academic approvals for all in-coming and out-going exchange and study abroad students.

- Audit transfer credit for returning exchange students and work with Transfer Services to ensure students receive proper credit for time abroad.

- Maintain budget for Undergraduate International Programs.

- Co-developed and traveled with College of Business faculty-led program for summer 2015 to Croatia and the Czech Republic for undergraduate students.

- Support students in connecting their international and college experiences to career goals.

- Advisor for Phi Beta Lambda-Future Business Leaders.

- Instructed 4 sections of Campus Culture (including Honors) with 300+ students total in 2017-2018 academic year.

International Coordinator, College of Business （February 2009-2013)

Coordinate exchange, dual-degree programs, and study abroad opportunities for Undergraduate students and exchange programs for MBA students in the College of 
Business. Educate students on international studies opportunities in over 400 appointments annually.

- Collaborate with international partner schools to place domestic students in study abroad and dual-degree programs.

- Oversee \$200,000 scholarship budget to promote study abroad.

- Serve as primary contact for 20+ incoming exchange students annually in the College of Business.

- Co-host University-wide pre-departure orientations for out-going study abroad students and assist with arrival of incoming exchange and international students each semester.

- Research ongoing policy changes regarding international study.

- Liaise with the International Center, Admissions, Housing, Registrar, and Bursar for incoming exchange students.

- Assist in the development of print and web content to promote International Programs.

- Present on the topic of study abroad to students, faculty, and other professional staff.

- Collaborate with academic and career counselors in order to best benefit students as they study abroad.

- Advise registered student organization-College of Business Global Cards.

- Travel to partner schools to facilitate professional relationships; visited 18 partner schools overseas.

\section{University-wide Committees}

Member of the SACS Compliance Certification Team.

Represent the College of Business on the International Affairs Advisor Committee. Member of the 21st Century Initiatives Committee international subcommittee. College of Business Representative to review Trustees Scholarship applications. Participate as a staff representative of the University-wide Student Conduct Board.

\section{TRANSYLVANIA UNIVERSITY August 2005-January 2009}

Private, four-year, liberal arts college located in Lexington, KY; 1100 FTE.

\section{Assistant Director of Residence Life}

Selected, trained, evaluated, assessed, and administered continuing education of

Residence Life Student Staff of three Head Advisers, 24 Residence Advisers, and 2

Alternate Resident Advisers. Advised and counseled students on an individual and group basis as needed.

- Oversaw \$11,000 Resident Advisor Training and hall program budget.

- Assisted with the opening of a new Residential facility.

- Adjudicated judicial cases.

- Sophomore Success Mentor

- Served as a member of the following committees:

- Student Retention Committee. 
- First-year Leadership Committee.

- Transylvanian Scholarship Selection Committee.

- Student Life Committee for Students' Stress Reduction.

- Student Life Wellness Committee.

- Advised the following groups:

- Sexual Harassment and Assault Resource Peer Educators.

- T-Unity (GLBTQ student group).

- Transy LEAD series committee.

\section{UNIVERSITY OF CINCINNATI September 2004-August 2005}

Public, four-year, research institution located in Cincinnati, OH; FTE 30,793 (24,752 undergraduate)

\section{Admissions Officer}

Recruited University of Cincinnati student body, represented University of Cincinnati in Northwest Ohio at college fairs and high school visits, planned admissions related events.

- Presented daily group recruiting sessions to prospective students and their families.

- Extensive event planning including Open Houses with 1200+ guests, Bus Tours, Information

- Fairs, Career Days, Counselor Open Houses and any other on-campus event hosted by the Admissions Office.

\section{DEPAUL UNIVERSITY/CHICAGO PUBLIC SCHOOLS September 2003- May 2004}

\section{GEARUP Student Advocate}

Assisted with college and career readiness training and leadership activities for high school students. Liaised between the GEARUP office and students, counselors, teachers, and parents within Rezin Orr High School, a Chicago Public School serving a low socioeconomic, predominantly African-American, population.

\section{SYMBIOTIX August 2002-September 2003}

Medical Communications company focused on project management and event planning in Danville, $K Y$.

\section{Event Planner Assistant (Contract Position)}

Traveled to on-site locations throughout the U.S. to assist with conferences and continuing education programs.

\section{LAKE FOREST COLLEGE June 2000-July 2002}

Private, four-year liberal arts college located in Lake Forest, IL; FTE 1493

\section{Admissions Officer}

Recruited Lake Forest College student body; represented Lake Forest nationally and locally at college fairs and high school visits, evaluated students' applications and made admissions decisions with a team. 


\section{INTERNSHIPS}

Dean of Students Office, University of Louisville

August 2012-June 2014

Researched Technology Coordinator position for the Disability Resource Center and created a rubric to check compliance related to state and federal financial aid for the Division of Student Affairs.

Greek Affairs Intern, Transylvania University

July 2006-December 2006

Assisted in planning and implementing men's and women's Greek recruitment.

Counseling Intern, Cristo Rey Jesuit High School

September 2003-May 2004

Counseled individual and groups of Latino students from a low socioeconomic area in Chicago on a social, emotional, health, and academic issues.

\section{LEADERSHIP and PROFESSIONAL ORGANIZATIONS}

Leadership Louisville, Ignite

October 2018- April 2019

Selected from a competitive applicant pool as a program participant

Matched with my team to work with Girls on the Run Kentuckiana

to develop a crowdfunding campaign, signature event, and other

fundraising mechanisms.

Association of International Educators (NAFSA)

State Conference delegate

Conference delegate

Region VI conference delegate

Kentucky Council on Education Abroad (KCEA)

2009-present

College Personnel Association of Kentucky (CPAK)

Past-President

2014, 2015, 2016, 2019

2013, 2015, 2018

2010

2011-present

2007-present

President

2012-2013

President-Elect

$2010-2012$

2009-2010

Executive Council, Small School Representative 2007-2009

Conference delegate

2007, 2008, 2009, 2010, 2011, 2013

College Student Educators International (ACPA)

2007-present

Annual Conference Local Arrangements Committee, Volunteer Chair

2012

Summer Leadership Meeting delegate

2011

Pre-conference workshop presentation

2010

Mid-Level Management Institute Host Committee Winter 2010

Summer Leadership Meeting Host Committee Summer 2009

Mid-Level Management Institute Participant

Winter 2009

Conference delegate

2008, 2010, 2012, 2014, 2017

Association for Student Conduct Administrators (ASCA)

Donald D. Gehring Institute Host Committee Summer 2011, Summer 2012

Regional Entry Level Institute participant (RELI) hosted by SEAHO 2007

Southeastern Association of Housing Officers (SEAHO)

2005-2009 
Annual conference host committee, Co-Chair of Public Relations

Committee

Conference delegate

2006, 2007

Kentucky Association of Housing Officers (KAHO)

Kentucky Resident Adviser Conference (KRAC)

Conference delegate

September 2005-2010

Co-Chair, Fall 2005

National Association of Student Personnel Administrators (NASPA)

Conference delegate

2005- 2009

2006

\section{PRESENTATIONS and PUBLICATIONS}

National

Creating Global Citizens: The Role of Study Abroad 2010

College Student Educators International (ACPA) Pre-Conference workshop

Regional and State

Tough Conversations in Education Abroad 2016

Association of International Educators Kentucky State Meeting (NAFSA-KY)

Dual-Degree Program Development 2015

Association of International Educators Kentucky State Meeting (NAFSA-KY)

Being Strategic and Meeting Students' Needs in an Office of One:

2014

Int'l Initiatives within an Academic Unit

Association of International Educators Kentucky State Meeting (NAFSA-KY)

Creating a Holistic International Program for Domestic: More than Study Abroad

Association of International Educators (NAFSA) Region VI

2011

Communication and Assessment

College Personnel Association of Kentucky Annual Conference 2010

Communication and Supervision for Professionals in Higher Education

College Personnel Association of Kentucky Annual Conference 2009

Communication and Supervision for Professionals in Residential Life

Kentucky Association of Housing Officers Annual Conference 2008

Technology and Communication: What LOL, BFF and TTYL Mean for Professionals in

Professionals in Higher Education

2008

College Personnel Association of Kentucky Annual Conference

Technology and Communication: What LOL, BFF and TTYL Mean for Professionals in Residence Life

Kentucky Association of Housing Officers 2007

Confounded Communication in Higher Education

College Personnel Association of Kentucky 2007

Confounded Communication in Residence Life: 
Southeastern Association of Housing Officers 2007

Confounded Communication in Residence Life

Kentucky Association of Housing Officers 2006

University

Student Leadership Legacy Series

Faceplant into Failure 2018

The Leader in Me: Leadership in a Global Context

2017-2018

Publication

The Aftermath: Fire Safety in Staff Housing

The SEAHO Report

\section{PERSONAL}

Site Based Decision Making Council Member-Hite, Louisville, KY

BSA Cub Scout Pack 71 Committee Chair

Younger Women's Club of Louisville, Louisville, KY

Lake Forest College Alumni Board, Associate Member, Lake

Forest, IL

2016-present

2018-present

2009-2015

Lexington Young Professional Association Member, Lexington, $\mathrm{KY}$

2007-2012

Kappa Alpha Theta Advisory Board Chair, Eastern Kentucky

$2005-2010$

University

2007-2010

Kappa Alpha Theta Education Advisor, Centre College

2006-2007 